Discussion Paper No. 05-77

Employment Effects of the Provision of Specific Professional Skills and Techniques in Germany

Bernd Fitzenberger and Stefan Speckesser

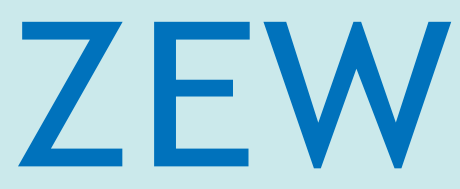

Zentrum für Europäische Wirtschaftsforschung $\mathrm{GmbH}$

Centre for European

Economic Research 


\section{Discussion Paper No. 05-77 \\ Employment Effects of the Provision of Specific Professional Skills and Techniques in Germany}

Bernd Fitzenberger and Stefan Speckesser

Download this ZEW Discussion Paper from our ftp server:

ftp://ftp.zew.de/pub/zew-docs/dp/dp0577.pdf

Die Discussion Papers dienen einer möglichst schnellen Verbreitung von neueren Forschungsarbeiten des ZEW. Die Beiträge liegen in alleiniger Verantwortung der Autoren und stellen nicht notwendigerweise die Meinung des ZEW dar.

Discussion Papers are intended to make results of ZEW research promptly available to other economists in order to encourage discussion and suggestions for revisions. The authors are solely responsible for the contents which do not necessarily represent the opinion of the ZEW. 


\section{Non-technical Summary}

Germany spends a considerable amount of money on active labor market policy (ALMP) to enhance the employment chances of the unemployed. Since appropriate data have not been available for a long time, reliable evaluation results on the employment effects of ALMP in Germany are rare. Nevertheless, there exists serious scepticism as to whether ALMP is actually effective. Contributing to this debate, this paper analyzes the employment effects of a particular type of public sector sponsored training in Germany for participants whose spell of receiving unemployment benefits starts in 1993 and who were employed shortly before. This study makes use of unique administrative data which has only recently become available. Using data on employment, periods of transfer payments, and participation in training programs, we carefully identify the provision of specific professional skills and techniques (SPST) in order to analyze the effects of a well defined treatment. SPST programs provide additional skills and specific professional knowledge in short- and medium-term courses, so they should have a good chance to enhance the employability of an unemployed person. SPST courses is the largest public sector sponsored training program among the unemployed.

The empirical analysis uses local linear matching based on the estimated propensity score to estimate the average treatment effect on the treated of SPST programs starting during 1 to 6,7 to 12 , and 13 to 24 months of unemployment. We evaluate the employment effects up to 36 months after the beginning of the program. We perform the analysis separately for East and West Germany. Matching procedes in two steps. After estimating the propensity score for the start of participation in one of the three time intervals, we only match individuals whose unemployment period started in the same calendar month and who are still unemployed without interruption until the month before treatment. Unemployed individuals who participate in the program in a later time interval are used as members of the control group for the earlier time interval for participation. The empirical results show a negative lock-in effect for the period right after the beginning of the program and significantly positive treatment effects on employment rates of about 10 percentage points and above in the second year after the beginning of the program. The general pattern of the estimated treatment effects is quite similar for the three time intervals of elapsed unemployment considered. The positive effects tend to persist almost completely until the end of our evaluation period. The positive effects are stronger in West Germany compared to East Germany. 


\title{
Employment Effects of the Provision of Specific Professional Skills and Techniques in Germany*
}

\author{
Bernd Fitzenberger $^{\dagger}$ and Stefan Speckesser ${ }^{\ddagger}$
}

September 2005

\footnotetext{
*This study is part of the project "On the effectiveness of further training programs. An evaluation based on register data provided by the Institute of Employment Research, IAB (Über die Wirksamkeit von Fortbildungs- und Umschulungsmaßnahmen. Ein Evaluationsversuch mit prozessproduzierten Daten aus dem IAB)" (IAB project number 6-531A). The data were compiled in this joint project with the Swiss Institute for Internationale Economics and Applied Economic Research at the University of St. Gallen (SIAW) and the Institut für Arbeitsmarkt- und Berufsforschung (IAB). We gratefully acknowledge financial support by the IAB. We benefitted from comments in seminars at ZEW Mannheim, IAB Nürnberg, Goethe University Frankfurt, and Stanford University. We thank Annette Bergemann, Stefan Bender, Reinhard Hujer, Michael Lechner, Konrad Menzel, Ruth Miquel, Don Rubin, Jeff Smith, Robert Völter, and Conny Wunsch for helpful discussions. All errors are our sole responsibility.

${ }^{\dagger}$ Corresponding author: Goethe University Frankfurt, ZEW, IZA, IFS. Address: Department of Economics, Goethe-University, PO Box 111932 (PF 247), 60054 Frankfurt am Main, Germany. E-mail: fitzenberger@wiwi.uni-frankfurt.de
}

${ }^{\ddagger}$ PSI London and Goethe University Frankfurt, Email: s.speckesser@psi.org.uk. 


\begin{abstract}
Based on unique administrative data, which has only recently become available, this paper estimates the employment effects of the most important type of public sector sponsored training in Germany, namely the provision of specific professional skills and techniques (SPST). Using the inflows into unemployment for the year 1993, the empirical analysis uses local linear matching based on the estimated propensity score to estimate the average treatment effect on the treated of SPST programs starting during 1 to 6,7 to 12 , and 13 to 24 months of unemployment. The empirical results show a negative lock-in effect for the period right after the beginning of the program and significantly positive treatment effects on employment rates of about 10 percentage points and above a year after the beginning of the program. The general pattern of the estimated treatment effects is quite similar for the three time intervals of elapsed unemployment considered. The positive effects tend to persist almost completely until the end of our evaluation period. The positive effects are stronger in West Germany compared to East Germany.
\end{abstract}

Keywords: training program, employment effects, administrative data, matching JEL: C 14, C 23, H 43, J 64, J 68 


\section{Contents}

1 Introduction $\quad 1$

2 Basic regulation of further training 2

2.1 Programs . . . . . . . . . . . . . . . . . . . 2

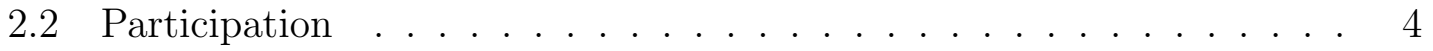

3 Data and type of treatment $\quad 4$

3.1 Employment and benefit data . . . . . . . . . . . . . 5

3.2 Monitoring data for training and the merged data set . . . . . . . . . 6

3.3 Contents and types of further training . . . . . . . . . . . 7

3.4 Provision of specific professional skills and techniques . . . . . . . 8

Inflow sample into unemployment and $\ldots \ldots \ldots \ldots \ldots \ldots$
participation by type of training . . . . . . . . . . . 10

4 Evaluation approach $\quad 11$

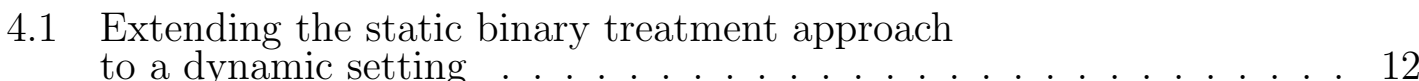

4.2 Details of the matching approach . . . . . . . . . . . . . 16

5 Empirical results $\quad 18$

5.1 Descriptive evidence on SPST training spells . . . . . . . . . . . . 18

5.2 Estimation of propensity score . . . . . . . . . . . . . . . 19

5.3 Treatment effects . . . . . . . . . . . . . . . . 21

6 Conclusions $\quad 25$

$\begin{array}{ll}\text { References } & 26\end{array}$

$\begin{array}{lr}\text { Appendix } & 29\end{array}$

$\begin{array}{lr}\text { Additional Data Appendix } & 1\end{array}$

1. Types of further training: A classification . . . . . . . . . . . . . . . 1

2. Identifying further training in merged data . . . . . . . . . . 5

3. Coding plan for the treatment information . . . . . . . . . . . . 8

4. Types of training and benefit payments . . . . . . . . . . . . . 18 


\section{Introduction}

Over the last decade, a number of studies has been conducted regarding the effectiveness of further training as part of active labor market policy in Germany, see Speckesser (2004, chapter 1) as a recent survey. Practically all the studies make use of survey data, such as the German Socio-Economic Panel [GSOEP]. ${ }^{1}$ Although these data are rich with respect to informative covariates, the evaluation studies summarized in the survey suffer from severe shortcomings with respect to the quality of the treatment information and to the precision of the employment history before and after treatment. Besides, most evaluation studies only assess the effects of such policies in East Germany. Finally, the samples sizes in these studies are typically small. They do not allow the researcher to evaluate the effects of any heterogeneous treatment or of treatments targeted to specific groups of individuals.

This evaluation study takes advantage of unique administrative data which involves register data on employment as well as data on unemployment and participation in active labor market programs generated by the Federal Employment Office (Bundesagentur für Arbeit). Our data set merges register data with benefit data and with survey data obtained from the local offices of the Federal Employment Office for participants in further training programs for the period 1980-1997 offering rich information on quite heterogeneous courses: further training (off-the-job) consists of a) the provision of specific professional skills, b) complete retraining of the employed to a new formal degree for a different profession, c) short-term courses which increase the search effectiveness of the individuals, and d) German language courses for immigrants, using a classification developped in this paper.

While the previous literature evaluates the employment effects for quite heterogeneous training programs, this paper focuses on quite a specific type of training which is defined by its economic purpose. Based on our classification of training types, we evaluate the employment effects of the most important type, the provision of specific professional skills.

Since the analysis is based on administrative data, this study has to use a nonexperimental evaluation approach. We build on the conditional independence as-

\footnotetext{
${ }^{1}$ Notable exceptions are the recent studies of Lechner et al. $(2005 \mathrm{a}, \mathrm{b})$ which are based on the same data set as our study. In fact, the data set is the outcome of a joint effort to merge administrative data for evaluation purposes, see Bender et al. (2004). The studies of Lechner et al. $(2005 \mathrm{a}, \mathrm{b})$ and our study differ a lot regarding the exact treatment definition, the choice of valid observations, and the econometric methods used.
} 
sumption purporting that for the treated and the non-treated the employment outcome in case of non-treatment is the same on average conditional on a set of covariates which cover socio-economic characteristics, the previous employment history of the individuals, the beginning of unemployment, and the elapsed duration of unemployment. The analysis uses the popular propensity matching approach adjusted to a dynamic setting building on the recent work by Frederiksson and Johansson (2003) and Sianesi (2004). In a dynamic setting, one has to take account of the timing of events, see also Abbring and van den Berg (2003, 2004). Our matching estimator is implemented using local linear matching (Heckman/Ichimura/Smith/Todd, 1998) with the crossvalidation procedure suggested in Bergemann et al. (2004).

The remainder of the paper is structured as follows: Section 2 gives a short description of the institutional regulation and participation figures for Active Labor Market Policy. Section 3 focuses on the different options of further training, their target groups, and course contents. Section 4 describes the methodological approach to estimate the treatment effects. The empirical results are discussed in section 5 . Section 6 concludes. The final appendix provides further information on the data and detailed empirical results. An additional data appendix provides detailed information on the construction of the data set.

\section{Basic regulation of further training}

\subsection{Programs}

For the period of our data, further training in Germany is regulated on the basis of the Labour Promotion Act (Arbeitsförderungsgesetz, AFG) and is offered and co-ordinated by the German Federal Employment Service (formerly Bundesanstalt für Arbeit, BA). It aims at improving occupational flexibility, career advancement and the prevention of skill shortages. However, following the persistent unemployment after the 70's, the programs of further training change their character from a preventive ALMP rather towards an intervention policy offered to unemployed and those who are at severe risk of becoming unemployed.

The increasing number of unemployed entering these programs changed the aims of the programs from the skill-upgrading programs that were focused on the employed to short-term programs in which individuals are taught new technologies and partial enhancement of existing skills for occupational re-integration. Although many 
changes concerning benefit levels and eligibility were implemented, the traditional policies further training, retraining, and integration subsidy remained unchanged until 97. In the following, we give a short description of these programs:

- Further training includes the assessment, maintenance and extension of skills, including technical development and career advancement (Weiterbildung). The duration of the courses depends on individual predispositions, other co-financing institutions and adequate courses provided by the training suppliers.

- Retraining enables vocational re-orientation if a completed vocational training does not lead to adequate employment (Umschulung). Retraining is supported for a period up to 2 years and aims a providing a new certified occupational skill.

- As third program of further training, integrations subsidies (Einarbeitungszuschuss) offer financial aid to employers providing employment to workers who have been unemployed or directly threatened by unemployment. It offers the grant for an adjustment period until the supported persons reach full proficiency in their job (up to $50 \%$ of the standard wage in the respective occupation).

- In 79, short-term training was introduced under $\S 41 \mathrm{a}$ AFG aiming to "increase prospects of integration". With this program, skill assessment, orientation and guidance should be offered to unemployed. The curricula under this program are usually short-term, lasting from two weeks up to two months and are intended to increase the placement rate of the unemployed.

Except for the integration subsidy which offers participants a standard salary (according to union wage contracts), participants are granted an income maintenance (Unterhaltsgeld) if the conditions of entitlement are satisfied. To qualify, persons must meet the requirement of being previously employed for a minimum duration, i.e. at least 1 year in contributory employment or receipt of unemployment benefit or subsequent unemployment assistance.

The income maintenance amounts to $67 \%$ of wages for participants with at least one dependent child, otherwise $60 \%$ which is equivalent to the unemployment benefit. However, benefits used to be much higher for the 80's and early 90's with up to $80 \%$ of previous net earnings granted. If a person does not fulfil the requirement of previous employment, but had received unemployment assistance until the start 
of the measure, an income maintenance may be paid as well. While participating in further training, participants requalify for unemployment insurance payments providing additional incentives to them to participate in programs. The BA bears all the costs of further training incurred directly through the training scheme, especially including course fees.

\subsection{Participation}

Among the three FuU programs, the general further training scheme (Berufliche Weiterbildung) is the most important in both East and West Germany. Starting with a total of 232,500 participants in $80,70 \%$ of all participants started a further training scheme, whereas only $14 \%(32,600)$ begin a program under the Integration subsidy (Eingliederungszuschüsse) scheme. New entrants into retraining summed up to 37,900 (Berufliche Umschulung, about $16 \%$ of total). On average, participant stock is about 89,300 in 80. In 85, participant entries are $60 \%$ higher in total. By then, further training programs amounted to $80 \%$ of all participant entries. Between 80 to 90 , participation increases to $514,600,74 \%$ of these are entries into further training programs. Participation in retraining increases from 37,900 in 80 to 63,300 in 90 .

When labor market policy is extended to East Germany, participation peaks at 887,600 entries in East Germany in 92 and 574,700 in West Germany, then declines to 378,400 in West Germany and 269,200 in East Germany in 96. The share of further training increases over time to $77 \%$ in West and to $76 \%$ in East Germany. The share of participants in retraining amounts to $20 \%$ in West and $18 \%$ in East Germany.

\section{Data and type of treatment}

This evaluation study is based on social insurance data for employment, on data involving transfer payments during unemployment, and on survey data for training participants reported by the local labor offices. The first data source is the IAB Employment Subsample (IABS) consisting of insurance register data for each employee recorded by the German social insurance system. Employees are usually subject to the mandatory social insurance system. The IABS additionally reports episodes, which individuals spent in unemployment involving benefit payments (Bender et al., 
2000). As the second data source, we use the reports by the German Employment Service on the structure, contents, duration, and benefit payment for participants in further training schemes. These reports were solicited as a monthly survey from the local labor offices in order to allow for internal and external monitoring (FuU-data, see Bender et al. 2004). Merging these two data sources, we can identify coherent types of further training. This is in contrast to earlier studies, which evaluate very heterogeneous types of treatment and which therefore provide much less informative evidence for policy makers.

\subsection{Employment and benefit data}

The core data for this evaluation are drawn from the Employment Subsample (Beschäftigtenstichprobe BST) of the Institute for Employment Research (IAB). The BST is a $1 \%$ random sample drawn from the mandatory employment register data for all employees who are covered by the social security system over the period 75-97. Social insurance contributions are compulsory for dependent employees earning above a minimum wage that is free of social insurance contributions. However, among the dependent employees specific groups working on a marginal part-time basis and civil servants are excluded. Although these groups are not sampled, the IABS covers more than $80 \%$ of the German labor force.

The second important source apart from the information of the BST is the benefit payment register (Leistungsempfängerdatei [LED]) of the Federal Employment Service. These data consist of spells for individuals who receive certain benefit payments from the BA. Besides unemployment benefit or assistance, these data also record very detailed information about income maintenance payments related to the participation in further training schemes.

Since the basic sampling of the IABS results from the employment register, only individuals who experience at least one spell of dependent employment between 75-97 are sampled. The sampling implies that one should restrict the analysis to entrants into programs from unemployment who were previously employed because the control group does not allow to construct a non-treatment outcome for treated individuals who did not experience registered unemployment before. The IABS samples roughly $1 \%$ of the overall dependent employment and benefit receipt, resulting in 591,627 individuals and in 8,293,879 spells over the period 75-97 for both East and West Germany. ${ }^{2}$

\footnotetext{
${ }^{2}$ However, the IABS, in the format that is available from the German central archive for empir-
} 


\subsection{Monitoring data for training and the merged data set}

The participation data are collected for all participants in further training, retraining, integration subsidies and language courses in Germany (FuU-data) for internal monitoring and statistics on the contents of further training that were regularly published. These data report information about the type of courses, the intended integration objectives and rough information about the contents of the courses with respect to the skills provided. They provide an overview about the persons in FuUprograms, the type of program, the aim of the courses, the type of training (whether the training takes place in classrooms or "on the job"), the provider of the program and the beginning and ending of the treatment and again personal characteristics of the participants (information about sex, age, nationality, the region in which the program takes place, the educational attainment, the employment status before treatment and other important characteristics). The data also indicate the type of income maintenance paid during the participation in a program. Sample size of the FuU-data amounts 54,767 individuals corresponding to 72,983 spells of treatment over the period 80-97 (for West Germany, and 91-7 for the new federal states). In principle, individuals receiving training related benefits that are sampled in the IABS should be part of the FuU-data. ${ }^{3}$

These data were merged to the IABS data by the social insurance number and additional covariates. Merged data supply an integrated evaluation database consisting of comparable, longitudinal information for treatment and control group that covers all participants in further training, retraining, integration subsidies and short-term training courses as well as language training.

In addition to merging the different files, numerous corrections are implemented in order to improve the quality of the data: Inconsistencies in both files, which occurred with respect to the reported level of education and occupational status, the year of birth and the family status, were removed. The correction of the variable providing information on the level of schooling and professional education is especially impor-

ical social research, does not report the receipt of benefit, if the BST reports employment at the same time. In such a case participants may be recorded as employed e.g. while doing an internship. This implies a structural underreporting of the treatment, and we merged the IABS a second time with the original benefit data, so payments parallel to dependent employment are included (resulting in an integrated data denoted as IABSLED in the following).

${ }^{3}$ However, there are exceptions to this rule: Since we find participants without any payment of income maintenance, using the merged data is the only option to fully identify the treatment group. 
tant for this study, because we assume the individual skills to be the decisive reason for an assignment into treatment. As the information on the individual's vocational training is provided by the employers, we assume that this reflects rather the level of education necessary to fulfil the tasks in the individual's current job. The individual's formal skill level may very well lie above the reported education level by the employer. A detailed description of the correction can be found in Bender et al. (2004, chapter 3$)$.

\subsection{Contents and types of further training}

The basic regulation of further training provides only a very basic framework, however no specific treatments with respect to integration targets or for target groups. Very different treatments can be implemented under the same regulation (e.g. training for career advancement or short-term courses for very long-term unemployed are both reported as "further vocational training"). Earlier descriptive studies ${ }^{4}$ on the types of treatment do not distinguish treatments providing basic social skills from treatments offering certified professional skills, which might have a very different impact on job search.

With the merged data of this study, we are able to identify specific types of further training while earlier papers usually evaluated bundles of very heterogeneous types of treatment. The combination of benefit data and FuU data allows us to identify whether a treatment is provided outside a firm specific labor market or within a firm, whether the course was general training or occupational specific. This paper is the first paper on further training in Germany that exploits all available information from administrative data, using the occupational status while being on training, the specific information about the benefit payments (which can be related to specific types of interventions) and a variable recording the type of training in the monitoring information on further training (FuU-data). ${ }^{5}$

\footnotetext{
${ }^{4}$ One of these studies based on the reported FuU-data by Blasche/Nagel (1995) does distinguish whether the training was carried out as an adjustment or a retraining and whether it was a full-time or part-time treatment.

${ }^{5}$ The training data should actually be sufficient to identify the extent of further training since they should have been collected for all training spells started under the AFG. However, there are two reasons which do not permit to rely only on the variable of type of training from the FuUdata: First, these training data are incomplete because data collection was not related to benefit payments. In such cases, administrative data are usually incomplete and the benefit information is required to identify the full extent of participation in the program. Secondly - and equally
} 
The combination of these different sources allows for an identification of informative (and coherent) types of treatment applying a typology relying on the type of training from FuU-data (see Bender et al. 2005, chapter 2.3 for a description of the FuUdata) and the closeness to the demands of the labor market as indicated by the IABS-data on employment status. Especially important are employment status and program information: While the program information "further vocational training" might comprise both employed and unemployed participants, the employment status allows additionally to identify the target group ("reintegration" for specific groups or unemployed or "career advancement" for employees) or to indicate how close the program is related to an internal labor market. A combination of training and employment data is more informative than the unmodified information from the training data, because the latter data do not specify details of the implementation and the target group of a program.

Based on the information from both sources, a range of different treatments can be identified, which range from the provision of social skills and basic general training over the provision of specific skills for the purpose of reintegration of the unemployed, the integration of unemployed into firm specific labor markets, retraining and the promotion of certified occupations up to career advancement training that used to be supplied to persons without the risk of unemployment (see Speckesser 2004 for a more detailed description about the different types of training). The first section of the additional data appendix provides a classification of different types of treatment carried out under the AFG regulation. It also shows how these very distinct types of training can be identified based on merged data.

\subsection{Provision of specific professional skills and techniques}

We evaluate the most important type of training that provides specific professional skills and techniques (SPST). This type of further training intends to improve the starting position for finding a new job by providing additional skills and specific professional knowledge in short-term and medium-term courses. It involves freshening up specific skills, e.g. computer skills, or training on new operational practises. SPST is targeted at unemployed or persons at risk of becoming unemployed in or-

important - the use of employment data and benefit data increases the precision of information on the type of training: It allows to find out whether a person was employed while being participant or whether a specific benefit was paid, both offering additionally valuable information about the participant's type of treatment. 
der to facilitate integration into full employment. This program basically consists of classroom training. In addition, an acquisition of professional knowledge by working experience is provided in most programs.

Participants usually obtain a certificate about the contents of the course, signaling refreshed or newly acquired skills and the amount of theory and work-experience achieved. Such a certificate sets an additional signal for potential employers and is supposed to increase the matching probability since the provision of up to date skills and techniques is considered to be a strong signal in the search process. The provision of specific professional skills and techniques aims to achieve the integration of unemployed by improving skills as well as by providing signals. Its role for a participant's occupational knowledge is therefore weaker than for retraining with a far more formal and thorough training providing a range of professional skills with an acknowledged certificate. However, the quantity of occupation specific knowledge certainly exceeds the level provided in short-term programs that usually aim at an improvment of job search techniques or general social skills. This type of training ranges in the middle of very formal (and very expensive) courses on the one hand and very informal and general courses on the other side.

This type of training was the most important type of training for the unemployment cohort used here (see descriptive statistics in section 3.5 based on our sample of unemployment inflows in 1993). Furthermore, the provision of specific professional skills and techniques still is the dominant type of training for unemployed today, see survey data for training providers showing which types of further training were mostly implemented in the year 2000 (Bundesministerium für Bildung und Forschung, 2000). These data allow the distinction of further training into the subcategories retraining, provision of specific skills and techniques, integration into firm specific labor markets and promotion (Table 2). It shows that the provision of specific skills and techniques is still the most important type with $36 \%$ of all cases and $35 \%$ of the volume (hours x cases). Together with the similar type of "other course" usually providing limited occupational knowledge as well, $67 \%$ of all cases in West Germany and $68 \%$ of the total volume provided specific professional skills and techniques. The data also shows the relatively smaller role of provision of specific skills and techniques in East Germany, where long-term retraining programs are still the most important form of training with $29 \%$ of the total volume of training and $20 \%$ of all courses. However, "other courses" (20\% of the total volume) and specific professional skills $(29 \%)$ are very important, too.

In light of the recent data on course contents, we believe that our evaluation of the 
program SPST is of particular interest for policy makers because this program is still the most important type of training today. Our evaluation using data for the 90's should therefore be regarded as a highly policy relevant contribution, providing long-term evidence for treatment effects in programs that are most similar to contemporary policies in place. Besides, we also expect SPST to be the most important type of training in future planning of further vocational training, see for example the recent report by the Federal Commission for Education Planning and Research, which stresses the importance of additional qualifications/complementary specific skills (BLK 2000, 3).

\subsection{Inflow sample into unemployment and participation by type of training}

We focus on the effect of training programs on employment chances of unemployed individuals. Therefore, we base our subsequent empirical analysis on an inflow sample into unemployment. We use the inflows into unemployment in the year 1993 both for East and West Germany and we estimate the effect of SPST on future employment rates. To be precise, we use individuals who experience a transition from employment to nonemployment and for whom a spell benefits transfer payments from the BA starts in the year 1993 before these unemployed individuals possibly find a new job. In the following, we denote the start of the benefit spell as the beginning of the unemployment spell. We condition on benefit recipiency to omit most individuals who move out of the labor force after losing their jobs. We choose the year 1993 because this is the second year observable for East Germany such that we can control for one year of labor experience before the beginning of unemployment. Our data allow to follow individuals until December 1997.

Participation in provision of specific professional skills and techniques and other types of training can be identified by either LED-data or FuU-data. In the best case, both sources provide coherent information about the treatment and one can easily identify the type of treatment from both data sources.

However, due to quality deficiencies in the participation data, many participants might not be recorded in the FuU-data. In this case, the LED-data helps to identify the treatment on the basis of the benefit variable which itself offers very specific information about the treatment. In other cases, we observe individual records showing employment in the IABS information and at the same time training in the FuU-data. This is for example the case if the treatment takes place in a firm and 
individuals are paid a normal salary (e.g. integration subsidy) or if individuals are prepared for precise job offers. Since we have two separate sources of data, we make use of all available information and combine benefit information with participation data in order to identify all different types of training. ${ }^{6}$

Table 3 provides information about the size of the inflow samples and the distribution of training. We only consider the three types of training programs, which are most suitable for unemployed individuals and which do not involve on-the-job training (training while working in a job). These are (i) Provision of specific professional skills (SPST), (ii) Preparation, social skills and short-term training (PST), and (iii) Qualification via the educational system and retraining (RT). The total inflow sample for West Germany comprises 18775 spells and 9920 spells for East Germany. The are 1500 training spells for West Germany and 1656 for East Germany. Among these, SPST represents by far the largest type of training with 895 SPST spells in West Germany and 1086 SPST spells in East Germany. Almost one fourth of all training spells involve RT and PST represents the smallest group both in West and East Germany. This paper focuses on SPST as the largest training program among the unemployed both in East and West Germany. In 1993, about 5\% of all unemployed in West Germany and more than $10 \%$ in East Germany participate in such a training program.

\section{Evaluation approach}

We analyze the employment effects of the provision of specific professional skills and techniques (SPST). Specifically, we estimate the average treatment effect on the treated (TT), i.e. the differential impact the treatment shows for those individuals who participate in an SPST course. We take the 1993 inflow sample into unemployment. Extending the static binary treatment framework to a dynamic setting, we distinguish three types of treatment depending upon the month in which the SPST course starts relative to the elapsed unemployment duration. We estimate the TT for participation in SPST against the comprehensive alternative nonparticipation in SPST which includes participation in another program of active labor market policy. Our dynamic evaluation approach following Sianesi (2004) applies

\footnotetext{
${ }^{6}$ Section 1 of the additional data appendix describes in details, which variables were required for this. Section 2 describes the precise coding plan. Table 13 in section 3 shows that many treatments would not have been detected or would have been coded differently, if we could not have used the combined information from both benefit and participation data.
} 
the standard static binary treatment approach recursively depending on the elapsed unemployment duration.

In the following, we first discuss our extension of the standard binary treatment approach to a dynamic setting. Then, we describe the implementation of the matching estimator for our problem.

\subsection{Extending the static binary treatment approach to a dynamic setting}

Our empirical analysis is based upon the potential-outcome-approach to causality (Roy, 1951, Rubin, 1974), see the survey Heckman/LaLonde/Smith (1999). We estimate the TT in the binary treatment case. $^{7}$ The individual treatment effect is the difference between the treatment outcome $Y^{1}$ and the nontreatment outcome $Y^{0}$, where the latter is not observed for the treated individuals. In a static context, $\mathrm{TT}$ is given by

$$
\Delta=E\left(Y^{1} \mid D=1\right)-E\left(Y^{0} \mid D=1\right),
$$

where $D$ denotes the treatment dummy.

We use the static binary treatment framework in a dynamic context. Our basic sample consists of individuals who start an unemployment spell with transfer payments in 1993 and who had been employed before. These individuals can participate in an SPST program at different points of time in their unemployment spell. Both the type of treatment and the selectivity of the treated individuals may depend upon the exact starting date of the program. Abbring and van den Berg (2003) and Frederiksson and Johansson (2003) interpret the start of the program as an independent random variable in the "timing of events". In a similar vein, Sianesi (2004) argues for Sweden that all unemployed individuals are potential future participants in active labor market programs, a view which is particularly plausible for countries with comprehensive systems of active labor market policies like Sweden or Germany. Unemployed individuals are not observed to participate in a program either because their participation takes place after the end of the observation period or because they leave the state of unemployment either by finding a job or by moving out of labor force.

\footnotetext{
${ }^{7}$ The framework can be extended to allow for multiple, exclusive treatments. Lechner (2001) and Imbens (2000) show how to extend standard propensity score matching estimators for this purpose.
} 
Frederiksson and Johansson (2003) argue that it is incorrect to undertake a static evaluation analysis by assigning unemployed individuals to a treatment group and a nontreatment group based on the treatment information observed in the data. Consider the case of analyzing treatment irrespective of the actual starting date during the unemployment spell. If one assigns individuals to the control group who find a job later during the observation period, one effectively conditions on future outcomes when defining the treatment indicator. This might lead to an upward bias in the estimated treatment effect. A downward bias can arise as well when future participants, whose participation starts after the end of the observation period, are assigned to the control group. This might possibly lead to an upward bias in the estimated treatment effect.

The above discussion implies that a purely static evaluation of SPST programs is not warranted. ${ }^{8}$ Therefore, we extend the static framework presented above in the following way. We analyze the employment effects of the first SPST program participation during the unemployment spell considered. ${ }^{9}$ Our basic sample consists of workers who started an unemployment spell receiving transfer payments by the Federal Labor Office in 1993 and who had been employed shortly before.

We distinguish between treatment starting during months 1 to 6 of the unemployment spell, treatment starting during months 7 to 12 , and treatment starting during months 13 to 24. Because our data end in 1997, we do not analyze treatments starting later than month 24 . We estimate the probability of treatment given that unemployment lasts long enough to make an individual 'eligible'. For the treatment during months 1 to 6 , we take the total sample of unemployed and estimate a Probit model for participation. The nontreatment group includes the unemployed who either never participate in SPST or who start treatment after month 6. For the treatment during months 7 to 12 or month 13 to 24, the basic sample consists of those unemployed who are still unemployed in the first month of the period considered, i.e. in month 7 and 13, respectively. We estimate a Probit of participating

\footnotetext{
${ }^{8}$ Under certain assumptions, drawing random starting times of the program is a valid alternative to use in this context, see e.g. Lechner (1999) and Lechner et al. (2005a,b) for this approach. However, this does not overcome all of the problems discussed here and we prefer to consider the timing of events explicitely. We do not introduce a random timing of the program starts among the nonparticipants for the following three reasons. First, random starting dates add noise to the data. Second, the drawn starting time might be impossible in the actual situation of the nontreated individual. Third, drawing random starting dates does not take the timing of events seriously.

${ }^{9}$ We do not analyze multiple sequential treatments, see Bergemann et al. (2004), Lechner and Miquel (2001), and Lechner (2004).
} 
during the considered time interval of elapsed unemployment duration using all individuals who are still unemployed in the first month of the period. Following Sianesi (2004), one should estimate a separate Probit model for different starting dates of unemployment and separate starting dates of the programs. In our case, the number of observations is too small for this. However, even if enough data were available, we think that it would not be advisable to estimate monthly Probit regressions. The reason is that the exact month when the treatment starts is somewhat due to available programs starting only at certain calendar dates. Therefore, we pool the treatment Probit for all inflows into unemployment in the three treatment periods assuming that the exact starting date month is random within the time interval considered. However, when matching treated and non-treated individuals, we impose perfect alignment in the starting month of the unemployment spell and the elapsed unemployment duration at the start of the program.

In the next step, we implement a stratified matching approach. First, we match participants and nonparticipants whose unemployment period starts in the same calendar month. A second requirement is that the nonparticipants are still unemployed in the month before the treatment starts. This way, we only match nonparticipants who might have started a treatment in the same month as the participants. The expression for the nontreatment outcome for the participants is then obtained through the local linear regression on the estimated propensity score among this narrow set of nonparticipants matched to the participants. This way, we obtain a perfect alignment in calendar time thus avoiding drawing random starting times of the program.

Our estimated TT parameter has to be interpreted in a dynamic context. We analyze treatment conditional upon the unemployment spell lasting at least until the start of the treatment and this being the first SPST treatment during the unemployment spell considered. Therefore, the estimated treatment parameter is

$$
\begin{gathered}
\Delta(t, \tau)=E\left(Y_{\tau}^{1} \mid D_{t}=1, U \geq t-1, D_{1}=\ldots=D_{t-1}=0\right) \\
-E\left(Y_{\tau}^{0} \mid D_{t}=1, U \geq t-1, D_{1}=\ldots=D_{t-1}=0\right)
\end{gathered}
$$

where $D_{t}$ is the treatment dummy for treatment starting in month $t$ of unemployment, $Y_{\tau}^{1}, Y_{\tau}^{0}$ are the treatment and nontreatment outcomes, respectively, in periods $t+\tau-1, \tau=1,2, \ldots$ counts the months (plus one) since the beginning of treatment, and $U$ is the duration of unemployment. Conditioning on past treatment decisions and outcomes, the treatment parameter for a later treatment period is not invariant with respect to changes in the determinants of the exit rates from unemployment or the treatment propensity in the earlier phase of the unemployment spell. This is a 
direct consequence of modelling heterogeneity with respect to the starting time of the treatment relative to the length of elapsed unemployment. Both the treatment group and the group of nonparticipants at the start of the treatment are affected by the dynamic sorting effects taking place before, see Abbring and van den Berg (2004) for a recent discussion of this problem in the context of estimating duration models. Thus, the estimated treatment parameter depends dynamically on treatment decision and outcomes in the past when taking the timing of events seriously (Abbring and van den Berg, 2003; Fredriksson and Johanson, 2003; Sianesi, 2004). To avoid this problem, one often assumes a constant treatment effect over the duration of elapsed unemployment at the program start. Alternatively, other suitable uniformity or homogeneity assumptions for the treatment effect could be used. Such assumptions are not attractive in our context.

Using propensity score matching in a stratified manner, we estimate the treatment parameter in (2) allowing for heterogeneity in the individual treatment effects and for an interaction of the individual treatment effects with dynamic sorting taking place. To make this a valid exercize, we assume the following dynamic version of the conditional mean independence assumption (DCIA) to hold for our inflow sample into unemployment

$$
\begin{aligned}
& E\left(Y_{\tau}^{0} \mid D_{t}=1, U \geq t-1, D_{1}=\ldots=D_{t-1}=0, X\right) \\
= & E\left(Y_{\tau}^{0} \mid D_{t}=0, U \geq t-1, D_{1}=\ldots=D_{t-1}=0, X\right),
\end{aligned}
$$

where $X$ are time-invariant (during the unemployment spell) characteristics and $Y_{\tau}^{0}$ is the nontreatment outcome in periods $\tau \geq 1$ (see also Sianesi, 2004, p. 137, for a similar discussion). We effectively assume that conditional on $X$, conditional on being unemployed until period $t-1$, and conditional on not receiving treatment before $t$ treated and nontreated individuals (both referring to treatment in period $t$ ) are comparable in their nontreatment outcomes in period $t$ and later.

The treatment parameter in (2) is interesting when each time period one decides whether to start treatment in the next month or whether to postpone possible treatment to the future (treatment now versus wating, see Sianesi, 2004). In addition, exits from unemployment in a certain period are not known in the period until they take place. Anticipation effects might invalidate this analysis, when the actual job arrival or the actual treatment is known some time beforehand. The former might introduce a downward bias in the estimated treatment effect while the latter might introduce an upward bias. This is a problem in any of the analyses based on the timing-of-events approach. However, it will not be a problem, if individuals anticipate the chances or the determinants of one of these events as long as this occurs 
in the same way for treated and nontreated individuals conditional on $X$ and the duration of elapsed unemployment in $t$.

By construction, treated individuals and their nontreated counterparts serving as controls exhibit the same unemployment duration until the beginning of the treatment. We investigate whether they differ in time-invariant unobserved characteristics by analyzing employment differences during 12 months before the start of the unemployment spell.

Finishing this section, one might be interested in knowing how our estimated treatment parameter in (2) relates to the static TT in (1), which is typically estimated in the literature. To relate the static TT to our dynamic setup, we define the treatment dummy $D=\sum_{t=1}^{T} D_{t} \cdot(U \geq t-1)$ indicating whether treatment starts during the time interval $[1, T]$. The outcome variables $\left(Y^{0}, Y^{1}\right)$ in (1) refer to the post treatment outcomes $\left(\tilde{Y}_{\tau}^{0}, Y_{\tau}^{1}\right)$ after the beginning of the treatment. Then, we have

$$
\begin{gathered}
E\left(Y_{\tau}^{1} \mid D=1\right)-E\left(\tilde{Y}_{\tau}^{0} \mid D=1\right) \\
=\sum_{t=1}^{T}\left[E\left(Y_{\tau}^{1} \mid D_{t}=1\right)-E\left(\tilde{Y}_{\tau}^{0} \mid D_{t}=1\right)\right] \cdot P\left(D_{t}=1 / D=1\right)
\end{gathered}
$$

where $\tilde{Y}_{\tau}^{0}$ represents the nontreatment outcome, either in employment or in unemployment, conditioning on no further treatment in the future. Thus, $E\left(Y_{\tau}^{1} \mid D_{t}=\right.$ $1)-E\left(\tilde{Y}_{\tau}^{0} \mid D_{t}=1\right)$ can not be related easily to $\Delta(t, \tau)$, since $\Delta(t, \tau)$ allows for the possibility of future treatment. Estimation of the different parameters has to account for different selection effects. However, in our application the group of treated individuals is quite small relative to the nontreatment group. Therefore, the static TT is likely to be close to the weighted average of the dynamic TTs $\Delta(t, \tau)$ with weights $P\left(D_{t}=1 / D=1\right)$ as in equation (4). It is not possible to sign the difference because our estimates for $\Delta(t, \tau)$ change sign with $\tau$ (see next section).

\subsection{Details of the matching approach}

Estimating the TT requires estimating the expected nontreatment outcome for the treated individuals. This estimation of the counterfactual is based upon the observed outcomes of the nontreated individuals. For this, we use a matching approach (Rosenbaum/Rubin, 1983; Heckman/Ichimura/Todd (1998); Heckman/LaLonde/Smith, 1999; Lechner, 1998) based on the estimated dynamic propensity score, as described in the previous section. We apply local linear matching to estimate the average nontreatment outcome of the treated individuals. 
Effectively, we run a nonparametric local linear kernel regression (Heckman/Ichimura/Smith/Todd, 1998; Pagan/Ullah, 1999; Bergemann et al., 2004) which can be represented by a weight function $w_{N_{0}}(i, j)$ that gives the higher weight to nonparticipant $j$ the stronger his similarity to participant $i$ regarding the estimated propensity score. The estimated TT can be written as

$$
\frac{1}{N_{1}} \sum_{i \in\{D=1\}}\left\{Y_{i, t}^{1}-\sum_{j \in\left\{D=0, u e_{j}=u e_{i}\right\}} w_{N_{0}}(i, j) Y_{j, t}^{0}\right\},
$$

with $N_{0}$ being the number of nonparticipants $j$ still unemployed right before treatment starts, $N_{1}$ being the number of participants $i$ in treatment depending on elapsed unemployment, and $u e_{i}, u e_{j}$ being the calendar month of the beginning of the unemployment spell $i, j$, respectively. $Y_{i, t}^{1}$ and $Y_{j, t}^{0}$ are the outcomes in the same calendar period $t$.

Matching estimators differ with respect to the weights attached to members of the comparison group. The most popular approach in the literature is nearest neighbor matching using the outcome of the closest nonparticipant $(j(i))$ as the comparison level for participant $i$, see Heckman et al. (1999) and Lechner (1998). In this case, $w_{N_{0}}(i, j(i))=1$ for the nearest neighbor $j(i)$ - as long as it is unique - and $w_{N_{0}}(i, j)=$ 0 for all other nonparticipants $j \neq j(i)$. In our case, the weights are implied by a nonparametric local linear kernel regression of the nontreatment outcome on the estimated propensity score. Kernel matching has a number of advantages compared to nearest neighbor matching. The asymptotic properties of kernel based methods are straightforward to analyze and it has been shown that bootstrapping provides a consistent estimator of the sampling variability of the estimator in (5) even if matching is based on closeness in generated variables (this is the case with the popular method of propensity score matching which will be discussed below), see Heckman, Ichimura, Smith, and Todd (1998) or Ichimura and Linton (2001) for an asymptotic analysis of kernel based treatment estimators. Abadie and Imbens (2004) show that the bootstrap is in general not valid for nearest neighbor matching due to its extreme nonsmoothness.

For the local linear kernel regression in the sample of nonparticipants, we use the Gaussian kernel, see Pagan/Ullah (1999). Standard bandwidth choices (e.g. rules of thumb) for pointwise estimation are not advisable here since the estimation of the treatment effect is based on the average expected nonparticipation outcome for the group of participants, possibly after conditioning on some information to capture the heterogeneity of treatment effects. To choose the bandwidth, we use the leaveone-out cross-validation procedure suggested in Bergemann et al. (2004) mimicking 
the estimation of the average expected nonparticipation outcome for each period. First, for each participant $i$, we identify the nearest neighbor $n n(i)$ in the sample of nonparticipants, i.e. the nonparticipant whose propensity score is closest to that of $i$. Second, we choose the bandwidth to minimize the sum of the period-wise squared prediction errors

$$
\sum_{t=T_{0}}^{T_{0}+35}\left[\frac{1}{N_{1, t}} \sum_{i=1}^{N_{1, t}}\left(Y_{n n(i), t}^{0}-\sum_{j \in\left\{D=0, u e_{j}=u e_{n n(i)}\right\} \backslash n n(i)} w_{i, j} Y_{j, t}^{0}\right)\right]^{2}
$$

where the estimation of the employment status for $n n(i)$ is not based on the nearest neighbor $n n(i)$ and $T_{0}=1,7,13$ is the first calendar month in the interval for unemployment duration $(1-6,7-12,13-24)$ during which the treatment begins. For the local linear regression, we only use those unemployment spells starting in the same month as for $n n(i)$. The optimal bandwidth affecting the weights $w_{i, j}$ through the local linear regression is determined by a one-dimensional search. The resulting bandwidth is sometimes larger and sometimes smaller than a rule-of-thumb value for pointwise estimation, see Ichimura/Linton (2001) for similar evidence in small samples based on simulated data.

We take account of the sampling variability in the estimated propensity score by bootstrapping the standard errors of the estimated treatment effects. To account for autocorrelation over time, we use the entire time path for each individual as block resampling unit. All the bootstrap results reported in this paper are based on 500 resamples. Since the bandwidth choice in (6) is computationally expensive, the sample bandwidth is used in all resamples.

\section{Empirical results}

\subsection{Descriptive evidence on SPST training spells}

Our empirical analysis is performed separately for West and East Germany. We restrict the data to the 25 to 55 years old in order to rule out periods of formal education or vocational training as well as early retirement. The analysis is based on the inflows from employment into unemployments which are associated with the start of a transfer payment by the Federal Labor Office during the year 1993. We observe 12320 such spells in West Germany and 7297 in East Germany. The analysis is based on spells, i.e. the sample involves more than one spell for individuals for whom we observe multiple unemployment spells with transfer payments in 1993 
and short employment spells between. An SPST treatment is associated with an unemployment spell if the individual does not start employment before the beginning of the treatment occurs. Therefore, in cases with multiple unemployment spells, a treatment after the beginning of the second unemployment spell is only recorded for the second unemployment spell but not for the first one. For the first unemployment spell we record no treatment and the outcome is set to not employed during the second unemployment spell and while receiving treatment. Note that the first spell of the same individual can not serve as a comparison observation for the treatment during the second spell because of the perfect alignment in calendar time when estimating the TT in equation (2).

Table 4 shows the number of unemployment spells with SPST treatment depending on the elapsed duration of unemployment. There are 751 treatment spells in West Germany and 971 in East Germany. Among these, 171 in West Germany and 217 in East Germany start during the first six months of unemployment, 147 and 227, respectively, during months 7 to 12 , 260 and 373, respectively, during the second year of unemployment, and 173 and 154, after two years of unemployment. SPST programs tend to start on average after a slightly longer elapsed duration of unemployment in West Germany compared to East Germany. Table 5 contains descriptive information on the starting dates. The average starting date is 16.6 months for West Germany and 15.1 months for East Germany. Considering the evidence for the three quartiles, the difference in the average arises mainly from the upper part of the distribution, i.e. the late starting dates in West Germany are later than in East Germany. Since the data for our analysis end in December 1997 and we analyze the employment outcome during 36 months after the beginning of the treatment, we only consider treatments starting during the first 24 months of unemployment. Table 5 provides descriptive information on the duration of training spells. In East Germany, durations are longer compared to West Germany. The average duration is about 2.4 months higher and the difference is slightly higher in the upper part of the distribution ( 4 months at the upper quartile) compared to the lower part of the distribution (2 months at the lower quartile).

\subsection{Estimation of propensity score}

To estimate the propensity score, we obtain Probit estimates for SPST training starting during the three time intervals for elapsed unemployment duration, i.e. 1-6 months (TR16), 7-12 months (TR712), and 13-24 months (TR1324). Tables 6 and 
7 report our preferred specifications for West and East Germany, which are obtained after extensive specification testing. The covariates considered are all time-invariant for an individual during the unemployment spell. The variable definitions are given in table 10. Personal characteristics considered are the age at the beginning of the unemployment spell (as five-year age dummies), dummy variables for gender, being a foreigner, state of residence (LAND), and formal education (BIL). We also use the month when the unemployment period starts (UE-ENTRY) and the employment status 6 and 12 months before the beginning of the unemployment spell (PRE-EX6, PRE-EX12). Finally, a number of characteristics of the previous job enter the specification, namely, broad industry indicators (WZW), job status (BER), firm size (GR), and information on earnings in the previous job. We use three variables containing information on earnings. Due to reporting errors and censoring problems, we do not know the earnings for all observations and we distinguish three cases. PENTG is a dummy variable for earnings above the minimum level to be subject to social security taxation. ${ }^{10}$ ENTGCENS is a dummy variable for earnings being topcoded at the social security taxation threshold (Beitragsbemessungsgrenze). LENTG is log daily earnings in the range between 15 Euro and the topcoding threshold and zero otherwise.

Our specification search starts with using all the covariates mentioned above without interactions. Then those covariates are dropped for which the Probit estimator cannot be obtained due to perfect predictions for certain values of the covariates. ${ }^{11}$ For the variables state, firm size, regional agglomeration, and industry information, we test whether the dummy variables are jointly significant. When insignificance is found, the covariates are dropped. Finally, we test for the significance of interaction effects of gender and age with a number of covariates. Only the significant effects remain in the specification and we did not find inconsistent test results regarding the sequence of tests performed. Finally, we investigate the goodness-of-fit for fairly narrow cells of observations based on the observed covariates. The predicted probabilities for our final preferred specification are in close correspondence to their

\footnotetext{
${ }^{10}$ In 1992, montly earnings below DEM 500 in West Germany and DEM 300 in East Germany for marginal part-time employees (geringfügig Beschäftigte) were not subject to social security taxation and should therefore not be present in the data. In addition, it was possible to earn at most twice as much in at most two months of the year. Probably due to recording errors, the data shows a number of employment reports with zero or very low earnings. Since this information is not reliable, we only use the information for daily earnings reported above 15 Euro as a conservative cut-off point.

${ }^{11}$ Such a situation would contradict the assumption required for propensity score matching that the treatment probability has to lie strictly between zero and one.
} 
empirical counterparts and simple goodness-of-fit tests show no rejection. These detailed results are available upon request.

The results for the Probit estimates in tables 6 and 7 show that the final specifications differ between the three time intervals and between West and East. Age effects are not significant in most cases except for TR1324 in West Germany. Firm size and industry are important for all treatment types in East Germany but only for early SPST programs (TR16 and TR712) in West Germany. For some covariates, the signs of the effects differ by treatment type, e.g. WZW5 (Construction) in East Germany seems to be associated with a later start of treatment. Remarkable regional differences exist in treatment assignment by states, especially in East Germany. Unemployed coming from large firms seem to be more likely to receive treatment. More highly educated individuals are more likely to receive early treatment in East Germany (especially at older ages for TR1324) and West Germany, with the exception of TR16 in West Germany. Foreigners are less likely to receive treatment (in East Germany, this holds only for TR16 and TR1324, but the number of foreigners is small here). Higher previous earnings increase the likelihood of receiving treatments TR16 and TR1324 in East Germany, whereas there are no clear cut effects in West Germany. Also, the month of entry into unemployment (seasonal effect) seems to play a role in East Germany but not in West Germany. White collar workers are more likely to receive treatment in a number of cases. In West Germany, females are less likely to participate in TR1324, and, when highly educated, in TR712. There is no significant gender effect for TR16 and females are more likely to participate in TR712 when they were white collar workers before. In East Germany, females are more likely to receive later treatments TR712 and TR1324 in a number of cases. There, younger females are more likely to receive TR712 and females from certain industries (WZW1,WZW2,WZW6) are more likely to receive TR1324. The estimation results show that the determinants of SPST program participation differs strongly by the elapsed unemployment duration.

\subsection{Treatment effects}

Based on the estimated propensity scores in the previous subsection, we match SPST participants and nonparticipants who started unemployment in the same month and we only use nonparticipants who are still unemployed in the month before treatment starts. The estimated TT is then estimated separately for month $\tau=1, \ldots, 36$ after the beginning of the SPST program according to equation (5) where the expected 
nontreatment employment outcome is obtained by means of a local linear regression on the propensity score ${ }^{12}$ among the nonparticipants considered. A comparison of the estimated propensity score for SPST participants and nonparticipants shows a close overlap for each stratum defined by the month of entry into unemployment and the beginning of the SPST treatment. ${ }^{13}$ We obtain an estimate for the variance of the estimated treatment effects through bootstrapping the entire observation vector for an observed spell in our inflow sample. This way, we take account of possible autocorrelation in the outcome variable. Inference is based on 500 resamples. ${ }^{14}$ As a preprogram test of the matching validity, we estimate in the same way the differences between participants and matched nonparticipants during months 1 to 12 before the treatment. By construction, participants and matched nonparticipants are unemployed between the beginning of their unemployment and the beginning of the treatment.

As a second test for the quality of matching, we use a standard t-test to assess whether the means of the observable $\mathrm{X}$-variables are statistically different from each other. We construct the observable characteristics of the matched controls based on the local linear regression used for matching and predict the covariates for the matched sample. The t-statistics represent the ratio of the difference in the two means in the treatment and the matched control group (numerator) to the estimated standard deviation of the mean difference in the numerator (denominator). A significant difference suggests a mismatch in the respective $\mathrm{X}$-variable.

The results of the tests are shown in tables 8 and 9 for the covariates used for the estimation of the propensity score: We never find a significant difference with respect to the observable characteristics between the treated and the matched control. In this case, the matching procedure is successful in using a suitable control group with respect to the observable covariates.

Figures 1-6 graphically represent the evaluation results. Each figure contains a panel of three graphs. The top graph involves the estimated average treatment effect for the treated during months 1 to 36 after the beginning of the treatment and the differences before months 1 to 12 before the beginning of the unemployment spell. The graph in the middle shows the average employment outcome for the treatment

\footnotetext{
${ }^{12}$ We use the fitted index $X_{i} \beta$ from the Probit estimates.

${ }^{13}$ These results are available upon request.

${ }^{14}$ This still fairly small number of resamples is due to the high computation time involved. However, results do seem to be quite reliable. Comparing the results based on 500 resamples with the results based on only the first 200 resamples, we do find any noticeable difference.
} 
group and the bottom graph shows the average estimated nontreatment outcome based on the matched nonparticipants. We put pointwise 95\%-confidence intervals around the estimates.

The patterns of the estimated treatment effects for months 1 to 36 after the beginning of the program are surprisingly similar across the different settings, even though the average employment rates in the middle and bottom graph decline for latter program starts. Treated individuals show an increase in employment rates during the first year and then remain at a fairly constant level during the second and third year. Only for late treatment TR1324 in West Germany, we observe a decline of about 10 percentage points (ppoints) after 2.5 years. In West Germany, treated individuals with early treatment TR16 reach an employment rate of about $60 \%$ after one year. For TR712, this lies around 50 to $55 \%$ and for TR1324 around 35 to $40 \%$. The expected average nontreatment outcome converges to a level of around $45 \%$ for TR16, around 30 to $35 \%$ for TR712, and around 20 to $25 \%$ for TR1324. As to be expected, the future employment chances for individuals decline with longer elapsed unemployment duration. Interestingly, the effect of the treatment seems to be quite similar, except for the decline at the end for TR1324. We find a negative lock-in effect for the period right after the beginning of the program and significantly positive treatment effects on employment rates of about 10 ppoints and above after a year. For TR712 in West Germany, the estimated treatment effect of aroung 20 ppoints is the highest among the three cases.

Though similar in nature, the results for East Germany show some differences. It takes about 1.5 years for the employment rates to reach their highest level. For TR16, the treatment group reaches an employment rate of about $60 \%$, for TR712 of about 45 to $50 \%$, and for TR1324 of about 35\%. For TR1324, we see a small decline at the end. The estimated nontreatment employment rates stabilize at a level of about $50 \%$ for TR16, about 35 to $40 \%$ for TR712, and about 25 to $30 \%$ for TR1324. Again for TR1324, we observe a small decline at the end. The estimated treatment effects again show a negative lock-in effect for the period right after the beginning of the program and a significantly positive treatment effect of about 10 ppoints after about 1.5 years. The long-run treatment effect is slightly lower for the later treatment TR1324, but still significantly positive.

A comprehensive cost-benefit analysis of the SPST program is not possible mainly for two reasons. First, we lack information on the monetary costs and on transfer payments during the treatment and the unemployment spell. Second, we can not analyze the employment effects after 36 months. As a first step to contrast the ini- 
tial negative lock-in effects of the programs with the later positive program effect, we calculate the cumulated effects of the program 12, 24, and 36 months after the beginning of the program (see Lechner et al., 2005a,b, for a similar exercise). The cumulated effects are calculated as the sum of the effects depicted in figures 1-6 starting in month 1 and summing up to months 12, 24, and 36, respectively. Table 11 provides the results. The estimated standard errors are based on the bootstrap standard errors for the month specific treatment effects. For West Germany, the cumulated effects after 12 months are still significantly negative for TR16 and positive but not significant for later treatments. The cumulated effects increase with longer time horizons and become significantly positive at a five percent significance level after 36 months (for TR712 already after 24 months) for a one-sided test. For East Germany, the longer duration of the treatment spells results in a stronger, significantly negative lock-in effect after 12 months. The cumulated effect is still negative after 24 months but only signficantly so for TR712. After 36 months the cumulated effects turn positive but they are still not significant. It is likely that a significantly positive cumulated effect can be found for an even longer time horizon for East Germany. This is not certain, however, since there is a slight tendency for the period specific effects to decline after about 2.5 years and since the standard errors tend to increase with a longer horizon.

It remains to discuss the estimated preprogram effects in figures 1-6 for the twelve months before the beginning of the unemployment spell. To be precise, these are the twelve months before the beginning of transfer payments by the Federal Labor Office after having lost the job. Individuals may have become unemployed earlier than this first month of unemployment period though having had a job in the recent past is a prerequisite for transfer payment. In fact, the employment rate among the treated lies somewhere between $75 \%$ and $90 \%$ during the twelve months before the start of transfer payments. In month -1 , the employment rate is above $80 \%$ in all case, i.e. in the vast majority of cases the start of the transfer payment coincides with the start of the unemployment spell. The estimated preprogram effect, i.e. the difference between the employment rates of the treatment group and the estimated employment rate of similar nontreated individuals, is not significantly different from zero in all cases, except for month -1 for TR1324 in East Germany. In the latter case, the rejection is not strong. Since all individuals become eventually unemployed in month 0 (the time between the beginning of the unemployment spell and the beginning of the treatment), our preprogram test should focus on the differences during the earlier phase of the twelve months before. For this earlier phase, there is no evidence of systematic differences in employment rates between treated and non- 
treated individuals after matching. This indicates that time-invariant unobserved heterogeneity does not invalidate our matching approach.

\section{Conclusions}

Based on a unique administrative data set for Germany, which has only been made available recently, we analyze the employment effects of the provision of specific professional skills and techniques (SPST) at the individual level. Specifically, we estimate the average treatment effect on the treated (TT), i.e. the differential impact the treatment shows for those individuals who participate in an SPST program. We take the 1993 inflow sample into unemployment and we distinguish three types of treatment depending upon the month in which the SPST course starts relative to the elapsed unemployment duration. We distinguish between the programs starting during 1 to 6,7 to 12 , and 13 to 24 months of unemployment. We estimate the TT for participation in SPST against the comprehensive alternative nonparticipation in SPST which includes participation in another program of active labor market policy. The analysis is conducted separately for West and East Germany.

The general pattern of the estimated treatment effects is quite similar for the three time intervals of elapsed unemployment considered. We find negative lock-in effects shortly after the treatment starts. After a while the effects turn positive and they persist almost completely until the end of our evaluation period. The positive effects are stronger in West Germany compared to East Germany and the lock-in effects are stronger in East Germany. The cumulated employment effects 36 months after the beginning of the treatment are significantly positive in West Germany. They are also positive for East Germany, but not significantly so. Our study draws a somewhat more positive picture of public sector sponsored training compared to most of the previous studies based on survey data. Our results are somewhat similar to those obtained in the studies Lechner et al. (2005a,b) based on the same data source, though the exact treatment definition, the choice of valid observations, and the employed econometric methods differ a lot between their studies and ours. However, an overall assessment of the microeconomic effects is not possible since various necessary information for a comprehensive cost-benefit-analysis are lacking in our data set. 


\section{References}

Abadie, and G. Imbens (2004). "On the Failure of the Bootstrap for Matching Estimators." Unpublished Discussion Paper, Harvard University and UC Berkeley.

Abbring, J. and G.J. van den Berg (2003). "The Nonparametric Identification of Treatment Effects in Duration Models." Econometrica 71:1491-1517.

Abbring, J. and G.J. van den Berg (2004). "Social Experiments and Instrumental Variables with Duration Outcomes." Unpublished Manuscript, Free University Amsterdam and Tinbergen Institute.

Ashenfelter, O. (1978). "Estimating the Effect of Training Program on Earnings." Review of Economics and Statistics 60:47-57.

Bender, S., A. Bergemann, B. Fitzenberger, M. Lechner, R. Miquel, S. Speckesser, C. Wunsch (2005). "Über die Wirksamkeit von Fortbildungs- und Umschulungsmaßnahmen", Beiträge zur Arbeitsmarkt- und Berufsforschung, IAB, Nürnberg.

Bender, S., A. Haas, and C. Klose (2000). "IAB employment subsample 19751995", Schmollers Jahrbuch, 120, 649-662.

Bender, S. and C. Klose (2000) "Berufliche Weiterbildung für Arbeitslose - ein Weg zurück in die Beschäftigung? Analyse einer Abgängerkohorte des Jahres 1986 aus Maßnahmen der Fortbildung und Umschulung mit der ergänzten IABBeschäftigtenstichprobe 1975-1990." Mitteilungen aus der Arbeitsmarkt- und Berufsforschung, 33(3):421-444.

Bergemann, A., B. Fitzenberger, and S. Speckesser (2004). "Evaluating the Dynamic Employment Effects of Training Programs in East Germany Using Conditional Difference-in-Differences." ZEW Discussion Paper, Mannheim.

BLK ([Bund/Länder/Kommission für Bildungsplanung und Forschungsförderung] 2000), Erstausbildung und Weiterbildung, Materialien zur Bildungsplanung und Forschungsförderung (83), Bonn: BLK

Blundell, R., M. Costa-Dias, C. Meghir, and J. Van Reenen (2003). "Evaluating the Employment Effects of a Mandatory Job Search Program." Discussion Paper 03-05 Department of Economics of the University College London.

Bundesanstalt für Arbeit (1993, 1997, 2001). Berufliche Weiterbildung. Nürnberg: Bundesanstalt für Arbeit (various issues).

Bundesanstalt fuer Arbeit (2003), Geschäftsbericht 2002, Nürnberg: Bundesanstalt für Arbeit. Einundfünfzigster Geschäftsbericht der Bundesanstalt für Arbeit,

Bundesministerium für Bildung und Forschung (2003), Berichtssystem Weiterbildung VII, Integrierter Gesamtbericht zur Weiterbildung in Deutschland, Berlin/Bonn: BMBF 
Fitzenberger, B. and H. Prey (2000). "Evaluating Public Sector Sponsored Training in East Germany." Oxford Economic Papers 52:497-520.

Fitzenberger, B. and S. Speckesser (2002). "Weiterbildungsmaßnahmen in Ostdeutschland. Ein Misserfolg der Arbeitsmarktpolitik?" In: Schmähl, W. (Hg.), Wechselwirkungen zwischen Arbeitsmarkt und sozialer Sicherung, Schriftenreihe des Vereins für Socialpolitik, Duncker und Humblodt.

Fredriksson, P. and P. Johanson (2003) "Program Evaluation and Random Program Starts." Institute for Labour Market Policy Evaluation (IFAU), Uppsala, Working Paper, 2003:1.

Frölich, M. (2001). "Nonparametric Covariate Adjustment: Pair-matching versus Local Polynomial Matching." Discussion Paper, University of St. Gallen.

Heckman, J., H. Ichimura, and P. Todd (1998). "Matching as an Econometric Evaluation Estimator." Review of Economic Studies 65:261-294.

Heckman, J., H. Ichimura, J. A. Smith and P. Todd (1998). "Characterizing Selection Bias using Experimental Data." Econometrica 65:1017-1098.

Heckman, J., R. J. LaLonde, and J. A. Smith (1999). "The Economics and Econometrics of Active Labor Market Programs." In: O. Ashenfelter and D. Card (eds.), Handbook of Labor Economics, Vol. 3 A, Amsterdam: Elsevier Science, 1865-2097.

Heckman, J. and R. Robb (1985). "Alternative Methods for Evaluating the Impact of Interventions." in: Heckman, J. and B. Singer (eds.), Longitudinal Analysis of Labor Market Data, New York: Wiley, 156-245.

Heckman, J. and J. A. Smith (1999). "The preprogram Earnings Dip and the Determinants of Participation in a Social Program: Implications for Simple Program Evaluation Strategies." Economic Journal 108:313-348.

Hujer, R. and M. Wellner (1999). "The Effects of Public Sector Sponsored Training on Unemployment and Employment Duration in East Germany." Discussion paper, Frankfurt: Goethe University.

Hujer, R., K.O. Maurer, and M. Wellner (1998). "Kurz- und langfristige Effekte von Weiterbildungsmaßnahmen auf die Arbeitslosigkeitsdauer in Westdeutschland." in: F. Pfeiffer and W. Pohlmeier (eds.), Qualifikation, Weiterbildung und Arbeitsmarkterfolg, ZEW Wirtschaftsanalysen, 31, Baden-Baden: Nomos Verlagsgesellschaft, 197-222.

Ichimura, H. and O. Linton (2001). "Asymptotic Expansions for some Semiparametric Program Evaluation Estimators." Discussion paper, London School of Economics and University College London.

Imbens, G. (2000). "The Role of the Propensity Score in Estimating Dose-Response Functions" Biometrica 87:706-710. 
Imbens, G. (2004). "Semiparametric Estimation of Average Treatment Effects under Exogeneity: A Review." Unpublished Manuscript. Biometrica 87:706710 .

Lechner, M. (1999). "Earnings and Employment Effects of Continuous Off-theJob Training in East Germany after Unification." Journal of Business and Economic Statistics, 17, 74-90.

Lechner, M. (2001). "Identification and Estimation of Causal Effects of Multiple Treatments under the Conditional Independence Assumption." In: M. Lechner and F. Pfeifer (eds.) (2000), Econometric Evaluation of Active Labor Market Politics in Europe, Heidelberg: Physica-Verlag.

Lechner, M. (2004). "Sequential Matching Estimation of Dynamic Causal Models." Discussion Paper 2004-06, University of St. Gallen.

Lechner, M. and R. Miquel (2001). "A Potential Outcome Approach to Dynamic Program Evaluation - Part I: Identification." Discussion Paper 2001-07, SIAW, University of St. Gallen.

Lechner, M., R. Miquel, and C. Wunsch (2005a). "Long-Run Effects of Public Sector Sponsored Training in West Germany." IZA Discussion Paper No. 1443.

Lechner, M., R. Miquel, and C. Wunsch (2005b). "The Curse and Blessing of Training the Unemployed in a Changing Economy: The Case of East Germany after Unification." Discussion Paper, University of St. Gallen.

Pagan A. and A. Ullah (1999). Nonparametric Econometrics. Cambridge: Cambridge University Press.

Rosenbaum, P. R. and D.B. Rubin (1983). "The Central Role of the Propensity Score in Observational Studies for Causal Effects." Biometrika 70:41-55.

Roy, A.D. (1951). "Some Thoughts on the Distribution of Earnings." Oxford Economic Papers 3:135-146.

Rubin, D. B. (1974). "Estimating Causal Effects of Treatments in Randomized and Nonrandomized Studies." Journal of Educational Psychology 66:688-701.

Sianesi, B. (2004) "An Evaluation of the Swedish System of Active Labor Market Programs in the 1990s." Review of Economics and Statistics, 86(1), 133-155.

Speckesser, S. (2004). "Essays on Evaluation of Active Labour Market Policy." Ph.D. Dissertation, Department of Economics, University of Mannheim.

Seifert, B. and T. Gasser (1996). "Finite-Sample Variance of Local Polynomials: Analysis and Solutions." Journal of the American Statistical Association 91:267-275. 


\section{Appendix}

Table 1: Participation in further training until 1997

\begin{tabular}{|c|c|c|c|c|c|}
\hline Year & \multicolumn{4}{|c|}{ Annual entries } & \multirow[t]{2}{*}{ Annual average stocks } \\
\hline & Total & aining & aining & bsidy & \\
\hline 1980 & 232,5 & 162,4 & 37,9 & 32,6 & 89,3 \\
\hline 1985 & 371 & 298,2 & 45,1 & 27,7 & 114,9 \\
\hline 1990 & 514,6 & 383,4 & 63,3 & 67,9 & 167,6 \\
\hline \multicolumn{6}{|l|}{1991} \\
\hline West: & 540,6 & 421,2 & 70,5 & 48,9 & 189 \\
\hline East: & 705,3 & 442,8 & 129,9 & 132,6 & 76,7 \\
\hline \multicolumn{6}{|l|}{1992} \\
\hline West: & 574,7 & 464,5 & 81,5 & 28,7 & 180,6 \\
\hline East: & 887,6 & 591 & 183,1 & 113,5 & 292,6 \\
\hline \multicolumn{6}{|l|}{1993} \\
\hline West: & 348,1 & 266 & 72,2 & 9,9 & 176,8 \\
\hline East: & 294,2 & 181,6 & 81,5 & 31,1 & 309,1 \\
\hline \multicolumn{6}{|l|}{1994} \\
\hline West: & 306,8 & 224,9 & 73,1 & 8,8 & 177,9 \\
\hline East: & 286,9 & 199,1 & 68,6 & 19,2 & 217,4 \\
\hline \multicolumn{6}{|l|}{1995} \\
\hline West: & 401,6 & 309,7 & 81,8 & 10 & 193,3 \\
\hline East: & 257,5 & 184,3 & 52,8 & 26,4 & 216,1 \\
\hline \multicolumn{6}{|l|}{1996} \\
\hline West: & 378,4 & 291,6 & 77,3 & 9,5 & 203,6 \\
\hline East: & 269,2 & 204,1 & 48,1 & 17 & 205 \\
\hline
\end{tabular}

Source: Amtliche Nachrichten der Bundesanstalt für Arbeit, several volumes 
Table 2: Type of further vocational training in East and West Germany, 2000

\begin{tabular}{l|cc|cc}
\hline \hline & \multicolumn{4}{|c}{ \% Share of ... } \\
& Participants Volume of hours \\
& West & East & West & East \\
\hline Type of course or content of further training & & & & \\
Retraining & 3 & 9 & 20 & 29 \\
Promotion & 10 & 6 & 22 & 7 \\
Integration & 18 & 17 & 15 & 15 \\
Specific Skills & 36 & 35 & 21 & 29 \\
Other course & 31 & 33 & 21 & 20 \\
No information & 1 & 0 & 0 & 0 \\
\hline Sum & 99 & 100 & 99 & 0 \\
\hline \hline
\end{tabular}

Source: Bundesministerium für Bildung und Forschung (2003): 272 
Table 3: Participation in first training program for 1993 inflow sample into unemployment - Program starts before a new job is found

\begin{tabular}{|c|c|c|c|}
\hline Training Program ${ }^{*}$ & Frequency & $\begin{array}{l}\text { Percent of } \\
\text { inflow sample }\end{array}$ & $\begin{array}{r}\text { Percent among } \\
\text { Treated }\end{array}$ \\
\hline \multicolumn{4}{|c|}{ West Germany } \\
\hline Provision of specific professional skills & 895 & 4.8 & 59.7 \\
\hline $\begin{array}{l}\text { Preparation, social skills } \\
\text { and short-term training }\end{array}$ & 250 & 1.3 & 16.7 \\
\hline $\begin{array}{l}\text { Integration via education } \\
\text { system/Retraining }\end{array}$ & 355 & 1.9 & 23.7 \\
\hline No training program above & 17275 & 92.0 & - \\
\hline Total inflow sample & 18775 & 100 & 100 \\
\hline \multicolumn{4}{|c|}{ East Germany } \\
\hline Provision of specific professional skills & 1086 & 10.9 & 65.6 \\
\hline $\begin{array}{l}\text { Preparation, social skills } \\
\text { and short-term training }\end{array}$ & 172 & 1.7 & 10.4 \\
\hline $\begin{array}{l}\text { Integration via education } \\
\text { system/Retraining }\end{array}$ & 398 & 4.0 & 24.0 \\
\hline No training program above & 8264 & 83.4 & - \\
\hline Total inflow sample & 9920 & 100 & 100 \\
\hline
\end{tabular}

* We exclude training programs which involve on-the-job training (Training for specific jobs and Direct integration/wage subsidy) or which involve a very small number of participants since they are not targetted on inflows into unemployment (Career advancement and Language training). 
Table 4: Number of SPST training spells

\begin{tabular}{c|c|c} 
& West Germany & East Germany \\
\hline Training starts during & & \\
1-6 months & 171 & 217 \\
7-12 months & 147 & 227 \\
13-24 months & 260 & 373 \\
$>24$ months & 173 & 154 \\
of unemployment & & \\
\hline Total & 751 & 971 \\
\hline
\end{tabular}

Table 5: Descriptive statistics on SPST training spells

\begin{tabular}{c|c|c} 
& West Germany & East Germany \\
\hline Elapsed Duration of Unemployment in months \\
\multicolumn{2}{c}{ at beginning of training spell } \\
Average & 16.6 & 15.1 \\
$25 \%$-Quantile & 7 & 7 \\
Median & 14 & 13 \\
$75 \%$-Quantile & 23 & 21 \\
\hline
\end{tabular}

Duration of training spell in months

\begin{tabular}{c|c|c} 
Average & 6.4 & 8.8 \\
$25 \%$-Quantile & 3 & 5 \\
Median & 6 & 9 \\
$75 \%$-Quantile & 8 & 12 \\
\hline
\end{tabular}


Table 6: Probit estimates SPST West Germany

\begin{tabular}{|c|c|c|c|c|c|c|}
\hline \multirow[b]{3}{*}{ Regressor } & \multicolumn{6}{|c|}{ Training starts during ... } \\
\hline & \multicolumn{2}{|c|}{ 1-6 months } & \multicolumn{2}{|c|}{$\begin{array}{l}\text { 7-12 months } \\
\text { of unemployment }\end{array}$} & \multicolumn{2}{|c|}{ 13-24 months } \\
\hline & Coef. & s.e. & Coef. & s.e. & Coef. & s.e. \\
\hline Intercept & -3.9611 & $(1.9868)$ & -12.4284 & $(2.3547)$ & -5.3992 & $(1.9309)$ \\
\hline Age30-34 & .0405 & $(.0896)$ & .1102 & $(.0970)$ & .0993 & $(.0892)$ \\
\hline Age35-39 & -.0929 & $(.2404)$ & .0717 & $(.1116)$ & .0795 & $(.2153)$ \\
\hline Age40-44 & -.0800 & $(.2481)$ & .0140 & $(.1177)$ & -.5197 & $(.2631)$ \\
\hline Age45-49 & .0146 & $(.2473)$ & -.0725 & $(.1328)$ & -.5563 & $(.2854)$ \\
\hline Age50-55 & -.1939 & $(.2477)$ & -.5735 & $(.1606)$ & -.9901 & $(.2897)$ \\
\hline WZW3 & .2139 & $(.1317)$ & .1351 & $(.1424)$ & & \\
\hline WZW4 & -.0638 & $(.1678)$ & .2637 & $(.1561)$ & & \\
\hline WZW5 & .1036 & $(.1644)$ & -.1000 & $(.1883)$ & & \\
\hline WZW6 & .1595 & $(.1283)$ & .0888 & $(.1378)$ & & \\
\hline WZW7 & -.0396 & $(.1373)$ & -.1457 & $(.1542)$ & & \\
\hline BER1 & -.0683 & $(.2961)$ & & & & \\
\hline BER2 & -.1961 & $(.1767)$ & .0592 & $(.2998)$ & -.0469 & $(.1467)$ \\
\hline BER3 & .0944 & $(.1750)$ & .0881 & $(.3072)$ & -.0136 & $(.1571)$ \\
\hline BIL2 & & & .3085 & $(.1502)$ & -.1176 & $(.0920)$ \\
\hline BIL4 & & & .5048 & $(.2227)$ & .1334 & $(.1576)$ \\
\hline LAND6 & .1228 & $(.1114)$ & & & & \\
\hline LAND7 & -.2926 & $(.1173)$ & & & & \\
\hline LAND9 & -.4152 & $(.1529)$ & & & & \\
\hline LAND10 & .2299 & $(.1041)$ & & & & \\
\hline LAND11 & -.2202 & $(.1087)$ & & & & \\
\hline LAND12 & -.1769 & $(.0952)$ & & & & \\
\hline GR2 & .1229 & $(.0803)$ & & & & \\
\hline GR3 & .1322 & $(.1230)$ & & & & \\
\hline GR4 & .2825 & $(.1045)$ & & & & \\
\hline Foreigner & -.1675 & $(.1122)$ & -.2011 & $(.1157)$ & -.2386 & $(.0885)$ \\
\hline Female & -.0621 & $(.0790)$ & .3695 & $(.3556)$ & -.1690 & $(.0706)$ \\
\hline PENTG & .5940 & $(.4868)$ & .0485 & $(.5396)$ & .2905 & $(.4195)$ \\
\hline LENTG & -.0210 & $(.1185)$ & .1080 & $(.1344)$ & -.0103 & $(.1066)$ \\
\hline
\end{tabular}


Table 6: Probit estimates SPST < continued $>$

\begin{tabular}{|c|c|c|c|c|c|c|}
\hline \multirow[b]{3}{*}{ Regressor } & \multicolumn{6}{|c|}{ Training starts during ... } \\
\hline & \multicolumn{2}{|c|}{ 1-6 months } & \multicolumn{2}{|c|}{$\begin{array}{l}\text { 7-12 months } \\
\text { of unemployment }\end{array}$} & \multicolumn{2}{|c|}{ 13-24 months } \\
\hline & Coef. & s.e. & Coef. & s.e. & Coef. & s.e. \\
\hline ENTGCENS & -.1249 & $(.4866)$ & .4753 & $(.5508)$ & -.2105 & $(.4374)$ \\
\hline PRE-EX6 & .1134 & $(.1079)$ & -.1207 & $(.1003)$ & .1100 & $(.0913)$ \\
\hline PRE-EX12 & .2125 & $(.0976)$ & .1670 & $(.1028)$ & .1107 & $(.0857)$ \\
\hline UE-Entry & .0045 & $(.0088)$ & .0427 & $(.0104)$ & .0156 & $(.0086)$ \\
\hline BER2*Age35-44 & -.1138 & $(.2636)$ & & & .1622 & $(.2265)$ \\
\hline BER3*Age35-44 & .2850 & $(.2553)$ & & & .3863 & $(.2363)$ \\
\hline BER2*Age $45-55$ & -.3141 & $(.2759)$ & & & .2609 & $(.2633)$ \\
\hline BER3*Age $45-55$ & .2814 & $(.2602)$ & & & .3389 & $(.2788)$ \\
\hline BIL2*Age40-55 & & & & & .5204 & $(.1713)$ \\
\hline BIL4*Age40-55 & & & & & .4740 & $(.2644)$ \\
\hline FEM*BER2 & & & -.3513 & $(.3488)$ & & \\
\hline FEM*BER3 & & & .2804 & $(.3359)$ & & \\
\hline FEM*BIL2 & & & -.4930 & $(.2123)$ & & \\
\hline $\mathrm{FEM}^{*} \mathrm{BIL} 4$ & & & -.5625 & $(.3247)$ & & \\
\hline Nobs & & 320 & & & & 92 \\
\hline
\end{tabular}


Table 7: Probit estimates SPST East Germany

\begin{tabular}{|c|c|c|c|c|c|c|}
\hline \multirow[b]{3}{*}{ Regressor } & \multicolumn{6}{|c|}{ Training starts during } \\
\hline & \multicolumn{2}{|c|}{ 1-6 months } & \multicolumn{2}{|c|}{$\begin{array}{l}\text { 7-12 months } \\
\text { of unemployment }\end{array}$} & \multicolumn{2}{|c|}{ 13-24 months } \\
\hline & Coef. & s.e. & Coef. & s.e. & Coef. & s.e. \\
\hline Intercept & 3.8672 & $(1.8963)$ & -14.6619 & $(.1465)$ & -4.8182 & $(1.9178)$ \\
\hline Age30-34 & .1303 & $(.1063)$ & .2743 & $(.1995)$ & .1842 & $(.1032)$ \\
\hline Age35-39 & -.1209 & $(.1191)$ & -.0703 & $(.2250)$ & -.1140 & $(.1136)$ \\
\hline Age40-44 & .1626 & $(.1084)$ & .2889 & $(.2020)$ & .0221 & $(.1763)$ \\
\hline Age45-49 & -.0541 & $(.1269)$ & .2954 & $(.2139)$ & -.0984 & $(.1823)$ \\
\hline Age50-55 & .0313 & $(.1050)$ & -.0936 & $(.2078)$ & -.2088 & $(.1699)$ \\
\hline WZW3 & .1144 & $(.1153)$ & .2619 & $(.1412)$ & .1786 & $(.2413)$ \\
\hline WZW4 & -.0740 & $(.1534)$ & -.0391 & $(.1748)$ & .5548 & $(.2738)$ \\
\hline WZW5 & -.3643 & $(.1443)$ & -.1562 & $(.1766)$ & .3592 & $(.2393)$ \\
\hline WZW6 & -.0557 & $(.1049)$ & .0912 & $(.1255)$ & .3257 & $(.2152)$ \\
\hline WZW7 & -.2255 & $(.1020)$ & .0045 & $(.1182)$ & .5163 & $(.2035)$ \\
\hline BER2 & -.2016 & $(.1282)$ & -.1154 & $(.1184)$ & & \\
\hline BER3 & .1142 & $(.1245)$ & .2890 & $(.1140)$ & & \\
\hline LAND2 & -.3239 & $(.1026)$ & -.1685 & $(.1192)$ & -.1392 & $(.1062)$ \\
\hline LAND3 & -.3250 & $(.1130)$ & -.2075 & $(.1223)$ & -.2607 & $(.1146)$ \\
\hline LAND4 & -.1120 & $(.0967)$ & -.0339 & $(.1405)$ & .0715 & $(.1035)$ \\
\hline LAND5 & -.2454 & $(.1151)$ & -.3723 & $(.1388)$ & -.2070 & $(.1192)$ \\
\hline GR2 & .0474 & $(.0841)$ & .0641 & $(.0877)$ & .2405 & $(.0837)$ \\
\hline GR3 & .1366 & $(.1105)$ & .0700 & $(.1168)$ & .4344 & $(.1038)$ \\
\hline GR4 & .2515 & $(.0999)$ & .2339 & $(.1043)$ & .2049 & $(.1010)$ \\
\hline BIL2 & .3443 & $(.1320)$ & .2317 & $(.1129)$ & .0029 & $(.1251)$ \\
\hline BIL4 & .4133 & $(.1684)$ & .2762 & $(.1631)$ & -.0470 & $(.2207)$ \\
\hline Foreigner & -.5187 & $(.3831)$ & & & -1.0256 & $(.3841)$ \\
\hline $\mathrm{R} 2$ & & & -.0322 & $(.1032)$ & & \\
\hline $\mathrm{R} 3$ & & & -.0574 & $(.2292)$ & & \\
\hline $\mathrm{R} 4$ & & & -.2557 & $(.1176)$ & & \\
\hline Female & -.0759 & $(.0744)$ & .3397 & $(.1904)$ & .7723 & $(.2137)$ \\
\hline PENTG & -1.2245 & $(.4480)$ & & & -.7781 & $(.3866)$ \\
\hline LENTG & .3858 & $(.1179)$ & & & .2910 & $(.1044)$ \\
\hline & xt pa & & & & & \\
\hline
\end{tabular}


Table 7: Probit estimates SPST < continued $>$

\begin{tabular}{|c|c|c|c|c|c|c|}
\hline \multirow[b]{3}{*}{ Regressor } & \multicolumn{6}{|c|}{ Training starts during ... } \\
\hline & \multicolumn{2}{|c|}{ 1-6 months } & \multicolumn{2}{|c|}{$\begin{array}{l}\text { 7-12 months } \\
\text { of unemployment }\end{array}$} & \multicolumn{2}{|c|}{ 13-24 months } \\
\hline & Coef. & s.e. & Coef. & s.e. & Coef. & s.e. \\
\hline ENTGCENS & 1.1345 & $(.5139)$ & & & 1.1531 & $(.4456)$ \\
\hline PRE-EX6 & -.2090 & $(.0959)$ & -.0894 & $(.0965)$ & & \\
\hline PRE-EX12 & .1823 & $(.0935)$ & -.0971 & $(.0880)$ & & \\
\hline UE-Entry & -.0268 & $(.0085)$ & .0568 & $(.0096)$ & .0112 & $(.0085)$ \\
\hline BIL2*Age4055 & & & & & .1594 & $(.1681)$ \\
\hline BIL4*Age4055 & & & & & .5031 & $(.2748)$ \\
\hline FEM $^{*}$ Age $30-34$ & & & -.0766 & $(.2393)$ & & \\
\hline FEM $^{*}$ Age $35-39$ & & & .2438 & $(.2627)$ & & \\
\hline FEM $^{*}$ Age $40-44$ & & & -.2864 & $(.2481)$ & & \\
\hline FEM $^{*}$ Age $45-49$ & & & -.6133 & $(.2753)$ & & \\
\hline FEM*Age50-55 & & & -.0751 & $(.2470)$ & & \\
\hline FEM*WZW3 & & & & & -.3496 & $(.2990)$ \\
\hline FEM*WZW4 & & & & & -.3898 & $(.3160)$ \\
\hline FEM*WZW5 & & & & & -.3027 & $(.3260)$ \\
\hline FEM*WZW6 & & & & & -.1008 & $(.2488)$ \\
\hline FEM*WZW7 & & & & & -.5145 & $(.2365)$ \\
\hline Nobs & & 297 & 506 & & & 517 \\
\hline
\end{tabular}


Table 8: Matching quality SPST West Germany

\begin{tabular}{|c|c|c|c|c|c|c|c|c|}
\hline \multirow[b]{4}{*}{ Variable } & \multicolumn{8}{|c|}{ Training starts during ... } \\
\hline & \multicolumn{5}{|c|}{ 1-6 months } & \multicolumn{3}{|c|}{ 7-12 months } \\
\hline & \multicolumn{8}{|c|}{ of unemployment } \\
\hline & Treated & Non-treated & Matched & t-test & Treated & Non-treated & Matched & t-test \\
\hline Age $30-34$ & 0.24 & 0.21 & 0.24 & -0.01 & 0.31 & 0.20 & 0.29 & 0.27 \\
\hline Age 35-39 & 0.15 & 0.13 & 0.14 & 0.45 & 0.15 & 0.13 & 0.16 & -0.11 \\
\hline Age $40-44$ & 0.13 & 0.12 & 0.13 & 0.12 & 0.14 & 0.12 & 0.13 & 0.10 \\
\hline Age 45-49 & 0.12 & 0.10 & 0.11 & 0.20 & 0.08 & 0.11 & 0.10 & -0.41 \\
\hline Age $50-55$ & 0.10 & 0.17 & 0.13 & -1.20 & 0.03 & 0.21 & 0.06 & -1.54 \\
\hline WZW3 & 0.23 & 0.18 & 0.23 & 0.07 & 0.20 & 0.20 & 0.20 & 0.01 \\
\hline WZW4 & 0.06 & 0.11 & 0.06 & 0.12 & 0.15 & 0.11 & 0.15 & 0.14 \\
\hline WZW5 & 0.06 & 0.10 & 0.05 & 0.53 & 0.07 & 0.07 & 0.07 & 0.11 \\
\hline WZW6 & 0.39 & 0.28 & 0.40 & -0.42 & 0.33 & 0.28 & 0.34 & -0.24 \\
\hline WZW7 & 0.19 & 0.23 & 0.19 & -0.20 & 0.15 & 0.22 & 0.16 & -0.09 \\
\hline BER1 & 0.01 & 0.01 & 0.01 & -0.11 & & & & \\
\hline BER2 & 0.33 & 0.60 & 0.32 & 0.25 & & & & \\
\hline BER3 & 0.56 & 0.27 & 0.56 & -0.05 & 0.47 & 0.58 & 0.45 & 0.45 \\
\hline LAND6 & 0.12 & 0.07 & 0.12 & 0.14 & 0.43 & 0.28 & 0.44 & -0.11 \\
\hline LAND7 & 0.08 & 0.13 & 0.08 & 0.16 & 0.73 & 0.67 & 0.73 & 0.00 \\
\hline LAND9 & 0.04 & 0.09 & 0.04 & -0.03 & 0.12 & 0.06 & 0.13 & -0.24 \\
\hline LAND10 & 0.16 & 0.08 & 0.15 & 0.32 & & & & \\
\hline LAND11 & 0.11 & 0.15 & 0.11 & -0.31 & & & & \\
\hline LAND12 & 0.15 & 0.20 & 0.15 & 0.03 & & & & \\
\hline GR2 & 0.44 & 0.44 & 0.44 & 0.11 & & & & \\
\hline GR3 & 0.10 & 0.11 & 0.10 & 0.07 & & & & \\
\hline GR4 & 0.22 & 0.17 & 0.22 & -0.06 & & & & \\
\hline Foreigner & 0.08 & 0.18 & 0.09 & -0.44 & 0.08 & 0.20 & 0.08 & -0.27 \\
\hline Female & 0.43 & 0.43 & 0.46 & -0.70 & 0.42 & 0.46 & 0.43 & -0.38 \\
\hline PENTG & 0.98 & 0.88 & 0.96 & 1.41 & 0.96 & 0.84 & 0.94 & 0.83 \\
\hline LENTG & 3.71 & 3.36 & 3.63 & 0.92 & 3.59 & 3.16 & 3.55 & 0.31 \\
\hline ENTGCENS & 0.05 & 0.03 & 0.06 & -0.47 & 0.05 & 0.03 & 0.06 & -0.22 \\
\hline PRE-EX6 & 0.91 & 0.82 & 0.90 & 0.43 & 0.80 & 0.80 & 0.80 & -0.16 \\
\hline PRE-EX12 & 0.88 & 0.76 & 0.88 & -0.02 & 0.85 & 0.79 & 0.84 & 0.08 \\
\hline
\end{tabular}


Table 8: Matching quality SPST West Germany (continued)

\begin{tabular}{|c|c|c|c|c|}
\hline \multirow[b]{2}{*}{ Variable } & \multicolumn{4}{|c|}{$\begin{array}{c}\text { Training starts during ... } \\
\text { 13-24 months } \\
\text { of unemployment }\end{array}$} \\
\hline & Treated & Non-treated & Matched & t-test \\
\hline Age $30-34$ & 0.23 & 0.18 & 0.23 & 0.04 \\
\hline Age 35-39 & 0.21 & 0.12 & 0.21 & 0.11 \\
\hline Age $40-44$ & 0.15 & 0.11 & 0.14 & 0.27 \\
\hline Age $45-49$ & 0.14 & 0.11 & 0.15 & -0.80 \\
\hline Age 50-55 & 0.09 & 0.24 & 0.11 & -1.30 \\
\hline WZW3 & & & & \\
\hline WZW4 & & & & \\
\hline WZW5 & & & & \\
\hline WZW6 & & & & \\
\hline WZW7 & & & & \\
\hline BER1 & & & & \\
\hline BER2 & & & & \\
\hline BER3 & 0.55 & 0.58 & 0.56 & -0.12 \\
\hline LAND6 & 0.34 & 0.28 & 0.33 & 0.39 \\
\hline LAND7 & 0.68 & 0.65 & 0.68 & -0.07 \\
\hline LAND9 & 0.11 & 0.06 & 0.10 & 0.20 \\
\hline LAND10 & & & & \\
\hline LAND11 & & & & \\
\hline LAND12 & & & & \\
\hline GR2 & & & & \\
\hline GR3 & & & & \\
\hline GR4 & & & & \\
\hline Foreigner & 0.13 & 0.21 & 0.13 & -0.19 \\
\hline Female & 0.36 & 0.48 & 0.37 & -0.32 \\
\hline PENTG & 0.92 & 0.81 & 0.91 & 0.82 \\
\hline LENTG & 3.59 & 3.04 & 3.57 & 0.26 \\
\hline ENTGCENS & 0.02 & 0.03 & 0.02 & -0.40 \\
\hline PRE-EX6 & 0.87 & 0.80 & 0.87 & 0.08 \\
\hline PRE-EX12 & 0.84 & 0.79 & 0.83 & 0.28 \\
\hline
\end{tabular}


Table 9: Matching quality SPST East Germany

\begin{tabular}{|c|c|c|c|c|c|c|c|c|}
\hline \multirow[b]{4}{*}{ Variable } & \multicolumn{8}{|c|}{ Training starts during ... } \\
\hline & \multicolumn{5}{|c|}{ 1-6 months } & \multicolumn{3}{|c|}{ 7-12 months } \\
\hline & & & & of une & loyment & & & \\
\hline & Treated & Non-treated & Matched & t-test & Treated & Non-treated & Matched & t-test \\
\hline Age $30-34$ & 0.21 & 0.18 & 0.20 & 0.31 & 0.22 & 0.14 & 0.20 & 0.71 \\
\hline Age $35-39$ & 0.12 & 0.16 & 0.11 & 0.10 & 0.19 & 0.14 & 0.19 & 0.07 \\
\hline Age 40-44 & 0.21 & 0.15 & 0.20 & 0.09 & 0.18 & 0.14 & 0.17 & 0.11 \\
\hline Age $45-49$ & 0.10 & 0.11 & 0.10 & -0.29 & 0.09 & 0.13 & 0.09 & -0.02 \\
\hline Age $50-55$ & 0.24 & 0.23 & 0.25 & -0.38 & 0.18 & 0.30 & 0.22 & -1.28 \\
\hline WZW3 & 0.17 & 0.10 & 0.17 & -0.02 & 0.14 & 0.10 & 0.13 & 0.18 \\
\hline WZW4 & 0.06 & 0.07 & 0.05 & 0.12 & 0.05 & 0.07 & 0.05 & -0.11 \\
\hline WZW5 & 0.06 & 0.11 & 0.05 & 0.23 & 0.03 & 0.08 & 0.03 & 0.11 \\
\hline WZW6 & 0.29 & 0.24 & 0.29 & -0.03 & 0.31 & 0.25 & 0.32 & -0.45 \\
\hline WZW7 & 0.27 & 0.34 & 0.28 & -0.25 & 0.41 & 0.37 & 0.39 & 0.36 \\
\hline BER2 & 0.42 & 0.61 & 0.42 & -0.05 & 0.34 & 0.58 & 0.32 & 0.46 \\
\hline BER3 & 0.50 & 0.29 & 0.49 & 0.19 & 0.54 & 0.29 & 0.54 & -0.16 \\
\hline LAND2 & 0.22 & 0.27 & 0.23 & -0.31 & 0.22 & 0.30 & 0.24 & -0.54 \\
\hline LAND3 & 0.13 & 0.18 & 0.13 & -0.01 & 0.19 & 0.19 & 0.18 & 0.16 \\
\hline LAND4 & 0.34 & 0.27 & 0.33 & 0.36 & 0.32 & 0.26 & 0.32 & 0.08 \\
\hline LAND5 & 0.13 & 0.16 & 0.14 & -0.12 & 0.10 & 0.15 & 0.11 & -0.44 \\
\hline GR2 & 0.41 & 0.47 & 0.40 & 0.14 & 0.41 & 0.45 & 0.41 & 0.06 \\
\hline GR3 & 0.14 & 0.13 & 0.14 & 0.22 & 0.11 & 0.13 & 0.12 & -0.02 \\
\hline GR4 & 0.25 & 0.16 & 0.25 & 0.02 & 0.27 & 0.18 & 0.26 & 0.40 \\
\hline $\mathrm{R} 2$ & 0.35 & 0.34 & 0.34 & 0.25 & 0.39 & 0.34 & 0.38 & 0.29 \\
\hline R3 & 0.04 & 0.02 & 0.04 & -0.17 & 0.02 & 0.02 & 0.02 & -0.51 \\
\hline $\mathrm{R} 4$ & 0.15 & 0.17 & 0.15 & -0.14 & 0.10 & 0.20 & 0.12 & -0.49 \\
\hline Foreigner & 0.00 & 0.02 & 0.00 & 0.04 & & & & \\
\hline female & 0.47 & 0.49 & 0.45 & 0.45 & 0.76 & 0.56 & 0.76 & 0.00 \\
\hline BIL2 & 0.81 & 0.80 & 0.81 & 0.04 & 0.84 & 0.75 & 0.83 & 0.55 \\
\hline BIL4 & 0.14 & 0.07 & 0.15 & -0.11 & 0.09 & 0.07 & 0.10 & -0.57 \\
\hline PENTG & 0.95 & 0.93 & 0.95 & 0.18 & & & & \\
\hline LENTG & 3.50 & 3.28 & 3.49 & 0.18 & & & & \\
\hline ENTGCENS & 0.02 & 0.03 & 0.02 & -0.07 & & & & \\
\hline PRE-EX6 & 0.82 & 0.83 & 0.81 & 0.66 & 0.77 & 0.81 & 0.75 & 0.58 \\
\hline PRE-EX12 & 0.83 & 0.77 & 0.83 & 0.01 & 0.70 & 0.77 & 0.69 & 0.38 \\
\hline
\end{tabular}


Table 9: Matching quality SPST East Germany (continued)

\begin{tabular}{|c|c|c|c|c|}
\hline \multirow[b]{2}{*}{ Variable } & \multicolumn{4}{|c|}{$\begin{array}{c}\text { Training starts during ... } \\
\text { 13-24 months } \\
\text { of unemployment }\end{array}$} \\
\hline & Treated & Non-treated & Matched & t-test \\
\hline Age $30-34$ & 0.19 & 0.13 & 0.16 & 1.42 \\
\hline Age 35-39 & 0.11 & 0.13 & 0.09 & 1.09 \\
\hline Age $40-44$ & 0.17 & 0.13 & 0.16 & 0.68 \\
\hline Age $45-49$ & 0.13 & 0.13 & 0.14 & -0.54 \\
\hline Age $50-55$ & 0.25 & 0.34 & 0.31 & -2.38 \\
\hline WZW3 & 0.07 & 0.11 & 0.07 & 0.21 \\
\hline WZW4 & 0.09 & 0.08 & 0.10 & -0.35 \\
\hline WZW5 & 0.05 & 0.07 & 0.04 & 0.66 \\
\hline WZW6 & 0.26 & 0.25 & 0.28 & -0.70 \\
\hline WZW7 & 0.42 & 0.36 & 0.41 & 0.32 \\
\hline \multicolumn{5}{|l|}{ BER2 } \\
\hline \multicolumn{5}{|l|}{ BER3 } \\
\hline LAND2 & 0.25 & 0.32 & 0.28 & -1.13 \\
\hline LAND3 & 0.15 & 0.18 & 0.13 & 1.01 \\
\hline LAND4 & 0.37 & 0.26 & 0.39 & -0.59 \\
\hline LAND5 & 0.12 & 0.15 & 0.11 & 0.34 \\
\hline GR2 & 0.46 & 0.43 & 0.45 & 0.37 \\
\hline GR3 & 0.19 & 0.12 & 0.19 & -0.14 \\
\hline GR4 & 0.20 & 0.20 & 0.21 & -0.51 \\
\hline \multicolumn{5}{|l|}{$\mathrm{R} 2$} \\
\hline \multicolumn{5}{|l|}{$\mathrm{R} 3$} \\
\hline \multicolumn{5}{|l|}{$\mathrm{R} 4$} \\
\hline Foreigner & 0.00 & 0.04 & 0.01 & -2.57 \\
\hline female & 0.75 & 0.59 & 0.76 & -0.36 \\
\hline BIL2 & 0.78 & 0.72 & 0.76 & 0.95 \\
\hline BIL4 & 0.08 & 0.07 & 0.09 & -0.69 \\
\hline PENTG & 0.93 & 0.85 & 0.91 & 1.34 \\
\hline LENTG & 3.28 & 2.94 & 3.18 & 1.56 \\
\hline ENTGCENS & 0.03 & 0.03 & 0.04 & -0.83 \\
\hline \multicolumn{5}{|l|}{ PRE-EX6 } \\
\hline PRE-EX12 & & & & \\
\hline
\end{tabular}


Table 10: Variable definitions

Label Definition

Dummy Variables

WZW1 Agriculture

WZW2 Basic materials

WZW3 Metal, vehicles, electronics

WZW4 Light industry

WZW5 Construction

WZW6 Production oriented services, trade, banking

WZW7 Consumer oriented services, organization and social services

LAND1 Mecklenburg-VP

LAND2 Berlin-Brandenburg

LAND3 Sachsen-Anhalt

LAND4 Sachsen

LAND5 Thueringen

LAND6 Schleswig-Holstein/Hamburg

LAND7 Niedersachsen-Bremen

LAND8 Nordrhein-Westfalen

LAND9 Hessen

LAND10 Rheinland-Pfalz/ Saar

LAND11 Baden-Wuerttemberg

LAND12 Bayern

BER1 Apprentice

BER2 Blue Collar Worker

BER3 White Collar Worker

BER4 Worker at home with low hours/MISSING

BER5 Part-time working

GR1 Firm Size (employment) missing or $<11$

GR2 Firm Size (employment) $>10$ and $<200$

GR3 Firm Size (employment) $>200$ and $<500$

GR4 Firm Size (employment) > 500

BIL1 No vocational training degree

BIL2 Vocational training degree

BIL3 Abitur/No vocational training degree

BIL4 University/College degree

BIL5 No education reported

R1 Rural area

R2 Medium population density

R3 Dense area

R4 Metropolitan area

PENTG Earnings positive (Earnings $>15$ Euro)

$<$ continued on next page $>$ 
Table 10: Variable definitions $<$ continued $>$

Label Definition

ENGTCENS Earnings censored at social security taxation threshold

PRE-EX6 employed six month before unemployment starts

PRE-EX12 employed six month before unemployment starts

Other Variables

LENTG $\log ($ Earnings $)$ for $P E N T G=1$ and ENTGCENS $=0$ 
Table 11: Cumulated average treatment effects

\begin{tabular}{l|cc|ccccc}
\hline & \multicolumn{6}{c}{ Training starts during ... } \\
& $1-6$ months & $\begin{array}{c}7-12 \text { months } \\
\text { of unemployment }\end{array}$ \\
\hline \multicolumn{7}{c}{ West Germany } \\
\hline$\ldots$ after & Coef. & s.e. & Coef. & s.e. & Coef. & s.e. \\
\hline 12 months & -1.18070 & .2201 & .403928 & .3395 & .061272 & .2192 \\
24 months & .013515 & .5532 & 2.90827 & .7772 & 1.52291 & .5283 \\
36 months & 1.60420 & .8799 & 5.54798 & 1.1616 & 3.15718 & .8003 \\
\hline \multicolumn{7}{|c|}{ East Germany } \\
\hline .. after & Coef. & s.e. & Coef. & s.e. & Coef. & s.e. \\
\hline 12 months & -1.62331 & .2391 & -1.56347 & .1743 & -1.01759 & .1443 \\
24 months & -.660957 & .5590 & -1.06095 & .4295 & -.529110 & .3670 \\
36 months & .580934 & .8202 & .246313 & .6885 & .413204 & .5667 \\
\hline
\end{tabular}


Figure 1: SPST Treatment West Germany months 1-6

Average treatment effect for participants in specific skills with previous unemployment 1-6 months, West Germany

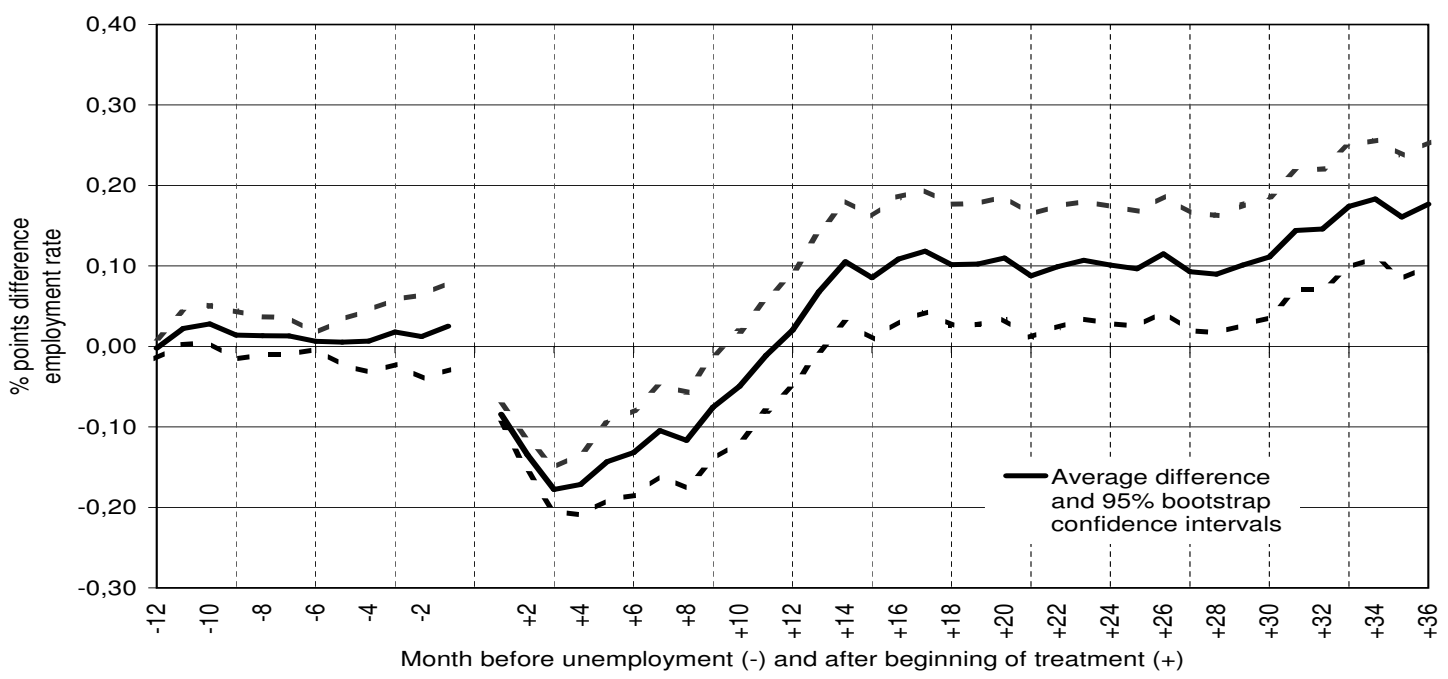

Employment rate for participants in specific skills with previous unemployment 1-6 months, West Germany

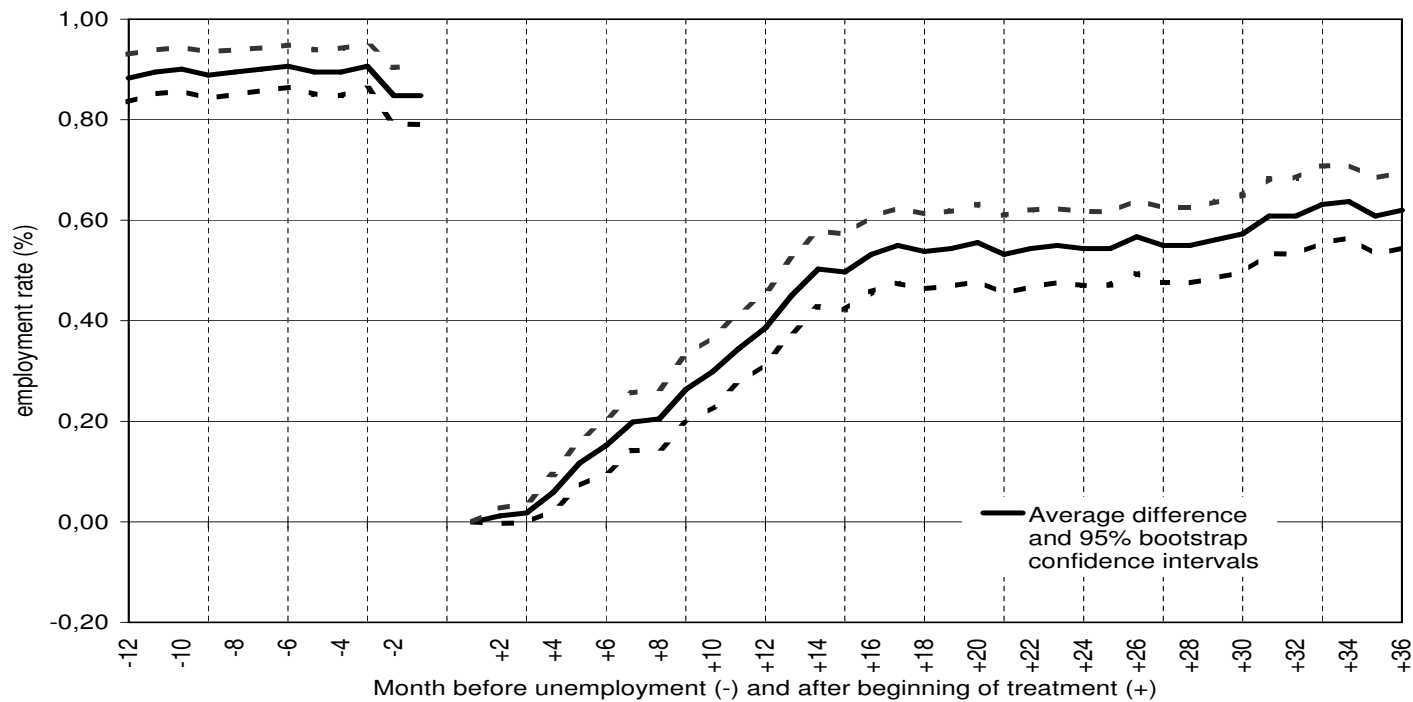

Estimated non-treatment employment for participants in specific skills with previous unemployment 1-6 months, West Germany

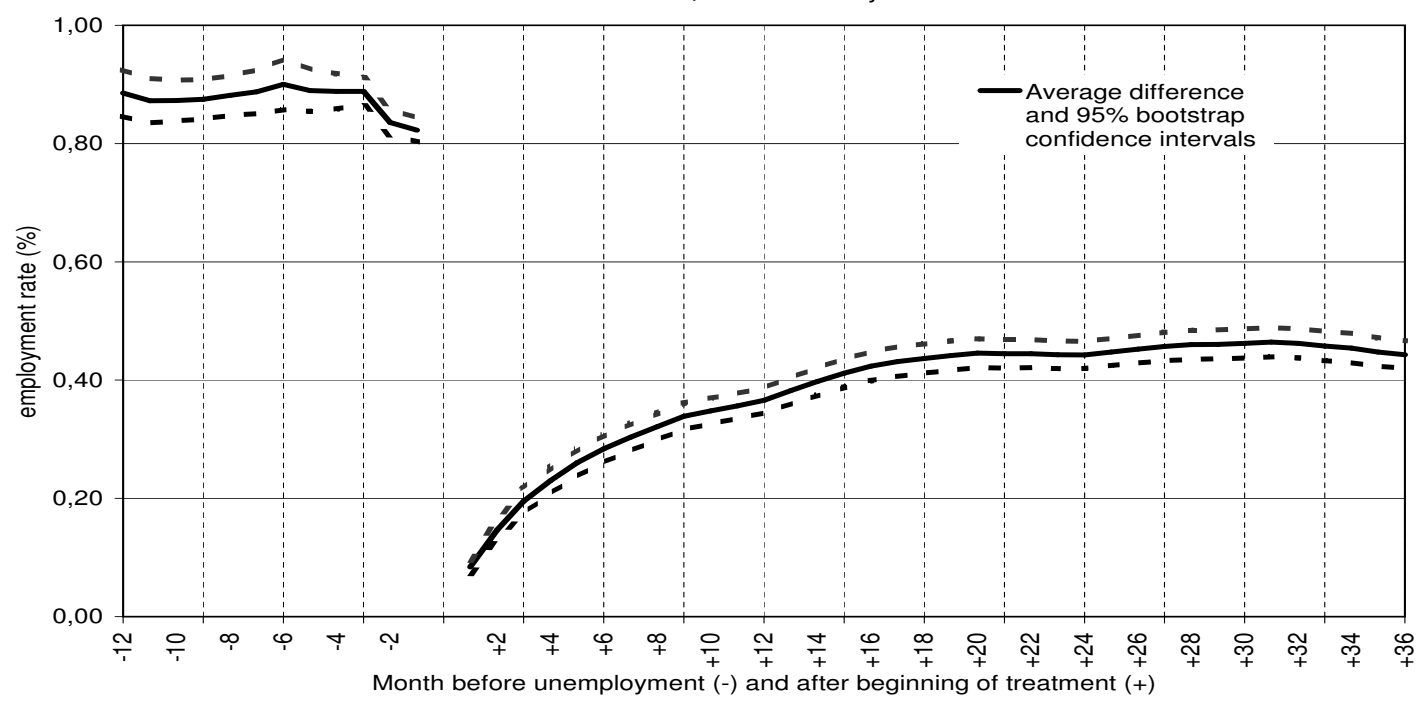


Figure 2: SPST Treatment West Germany months 7-12

Average treatment effectfor participants in specific skills with previous unemployment 7-12 months, West Germany

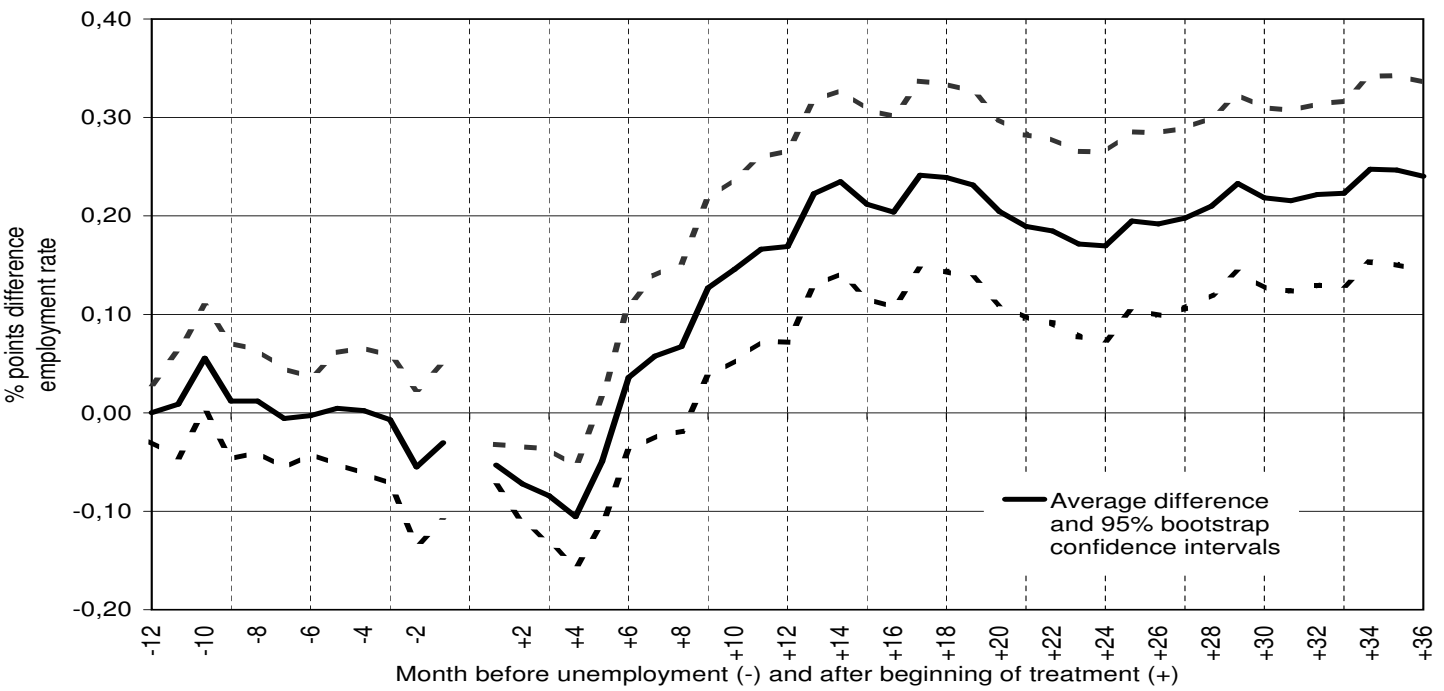

Employment rate for participants in specific skills with previous unemployment 7-12 months, West

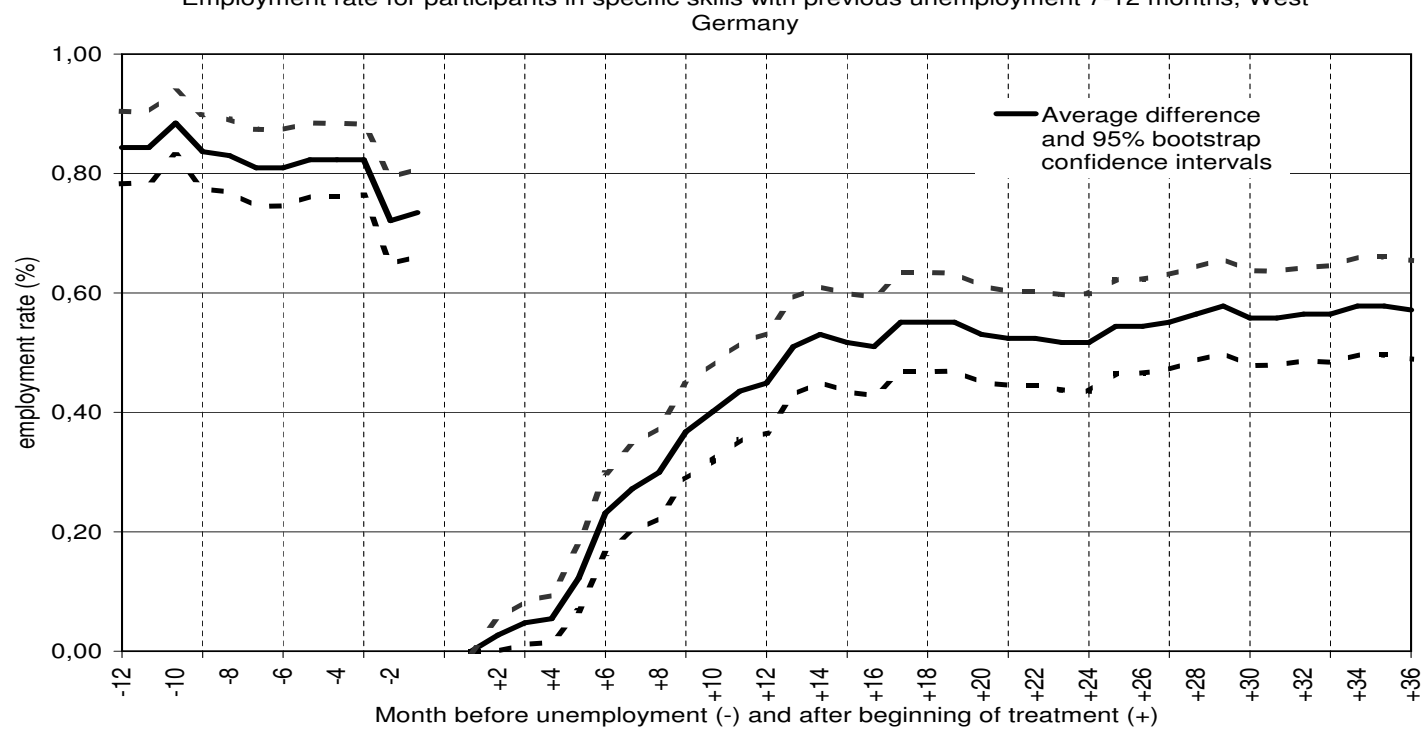

Estimated non-treatment employment for participants in specific skills with previous unemployment 7-12 months, West Germany

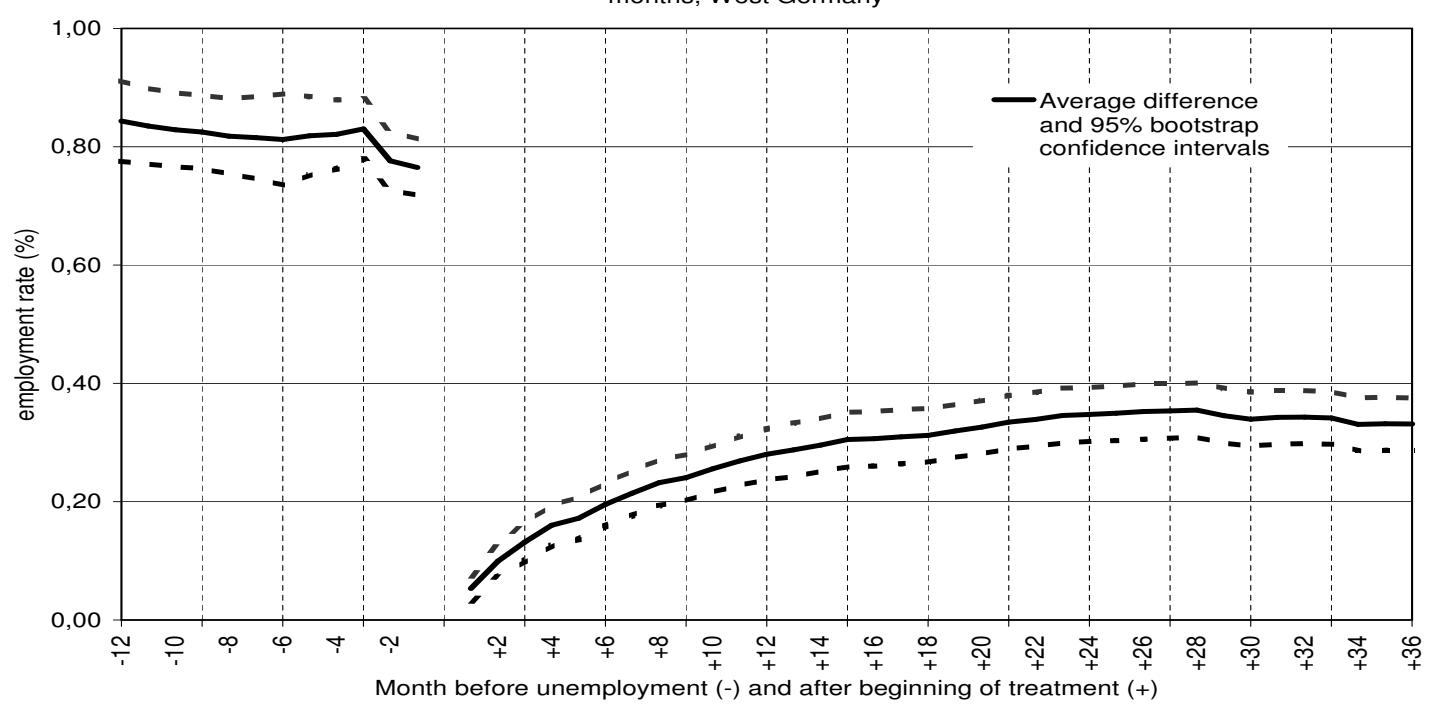


Figure 3: SPST Treatment West Germany months 13-24

Average treatment effect for participants in specific skills with previous unemployment 13-24 months, West Germany

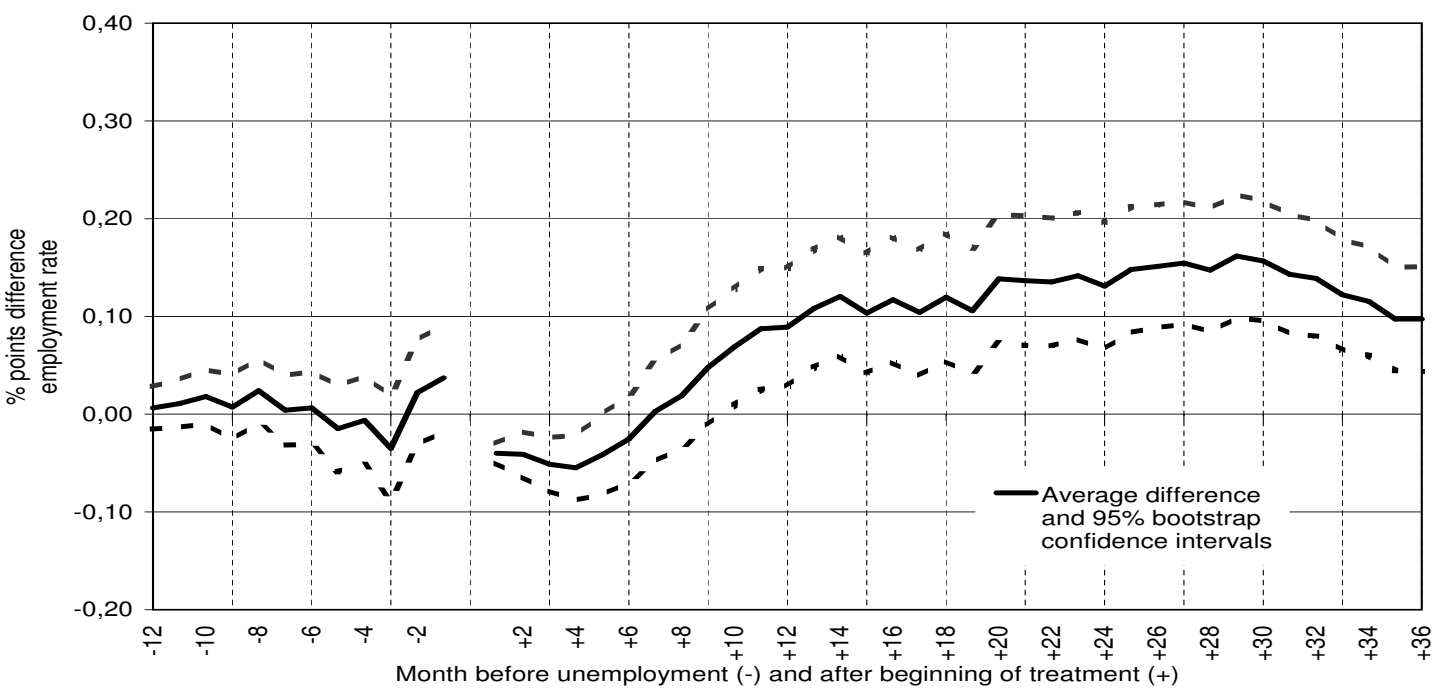

Employment rate for participants in specific skills with previous unemployment 13-24 months, West

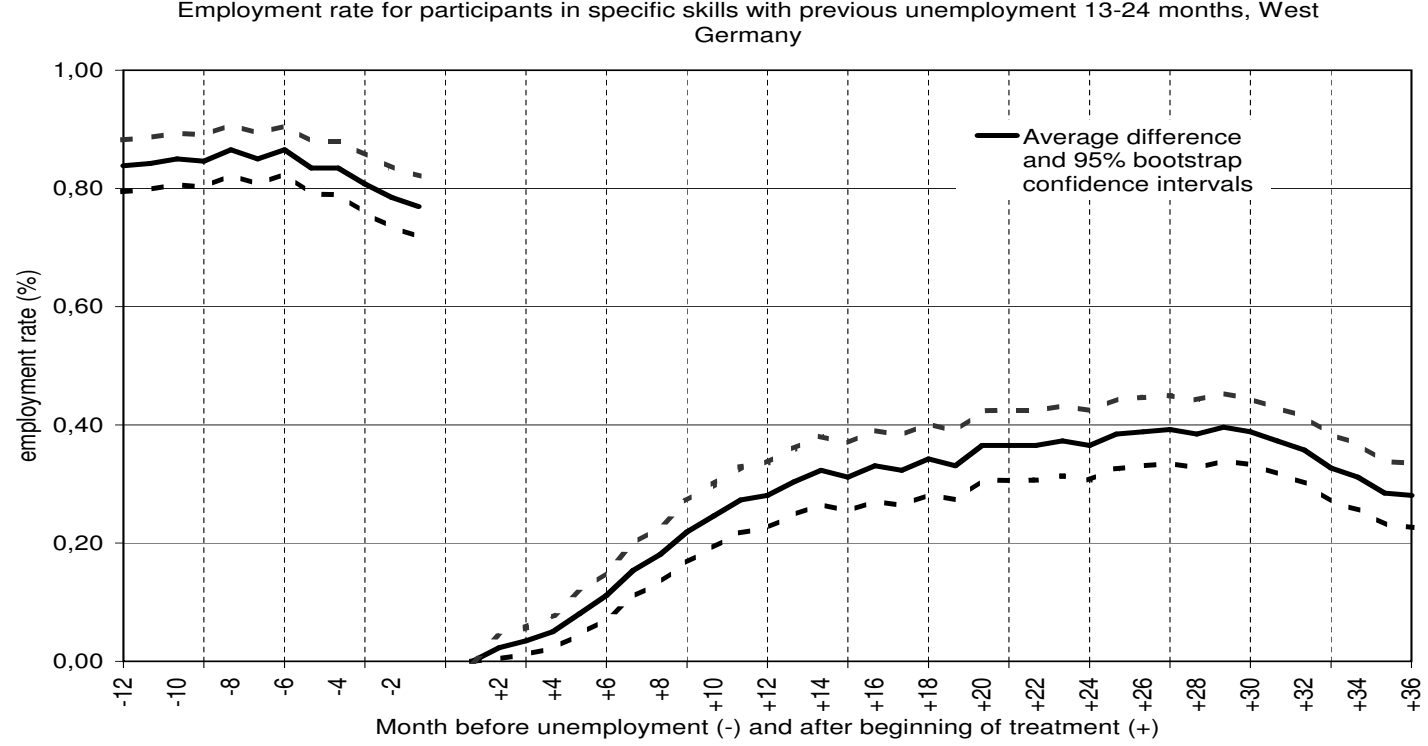

Estimated non-treatment employment for participants in specific skills with previous unemployment 13-24 months, West Germany

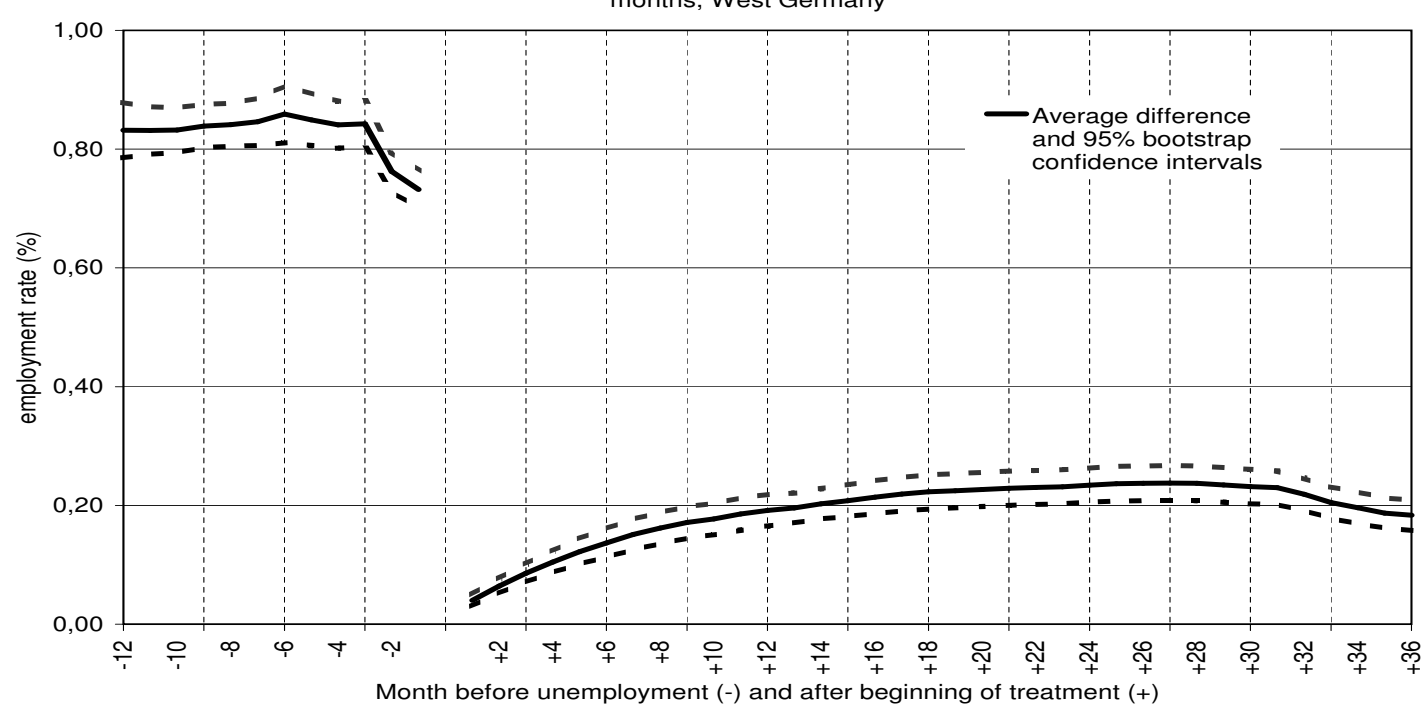


Figure 4: SPST Treatment East Germany months 1-6

Average treatment effect for participants in specific skills with previous unemployment 1-6 months, East Germany

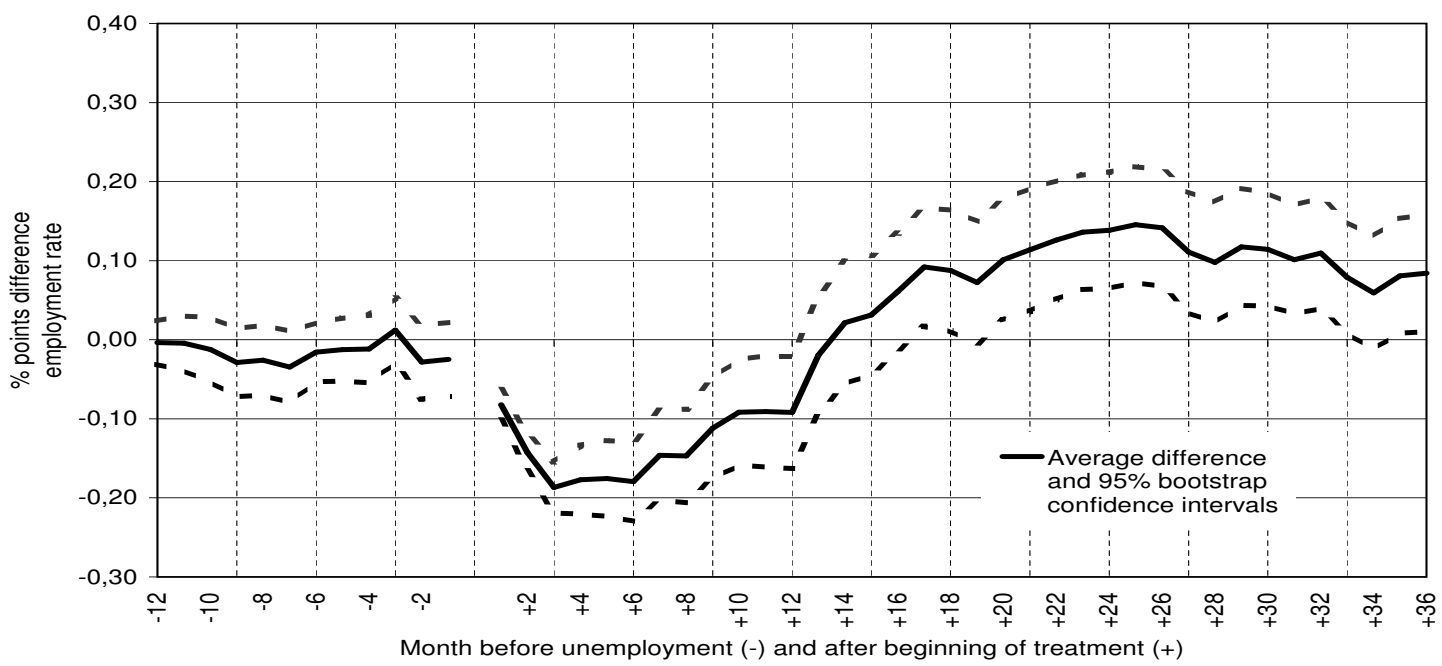

Employment rate for participants in specific skills with previous unemployment 1-6 months, East Germany

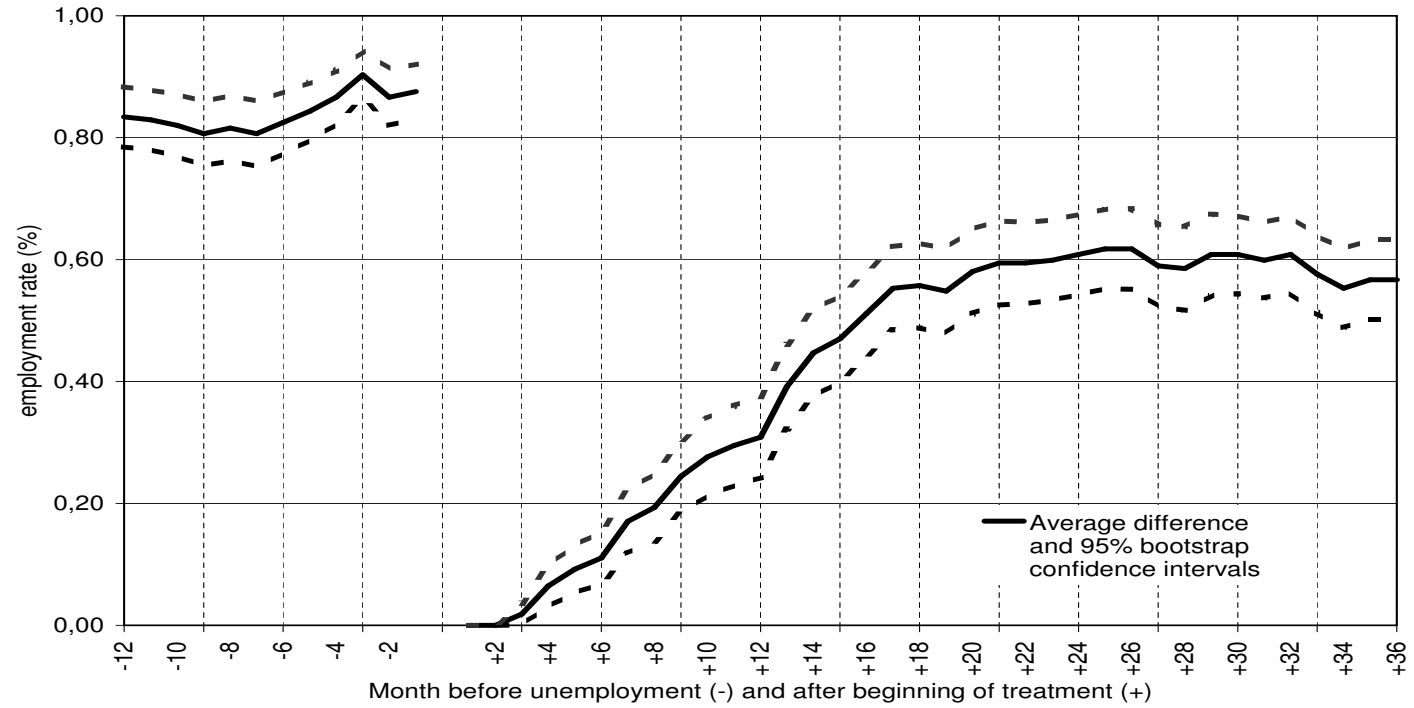

Estimated non-treatment employment for participants in specific skills with previous unemployment 1-6 months, East Germany

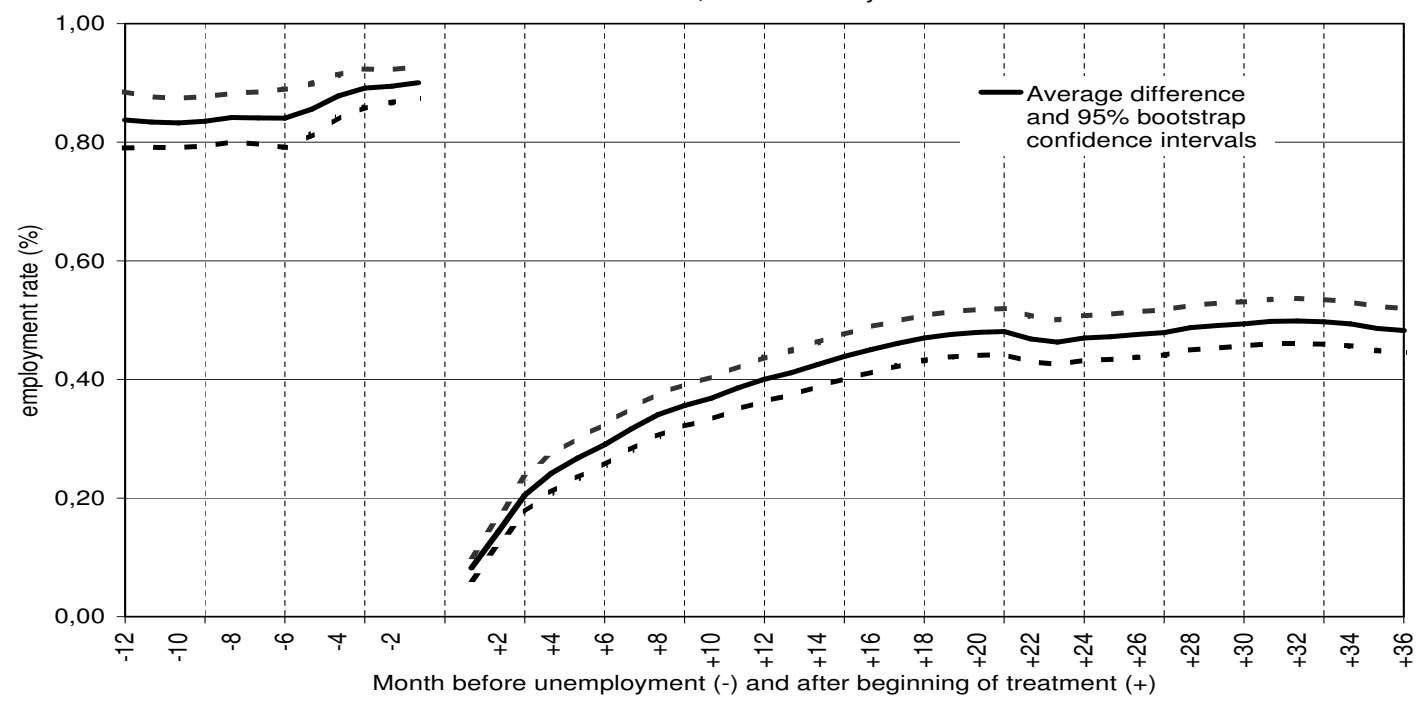


Figure 5: SPST Treatment East Germany months 7-12

Average treatment effect for participants in specific skills with previous unemployment 7-12 months, East Germany

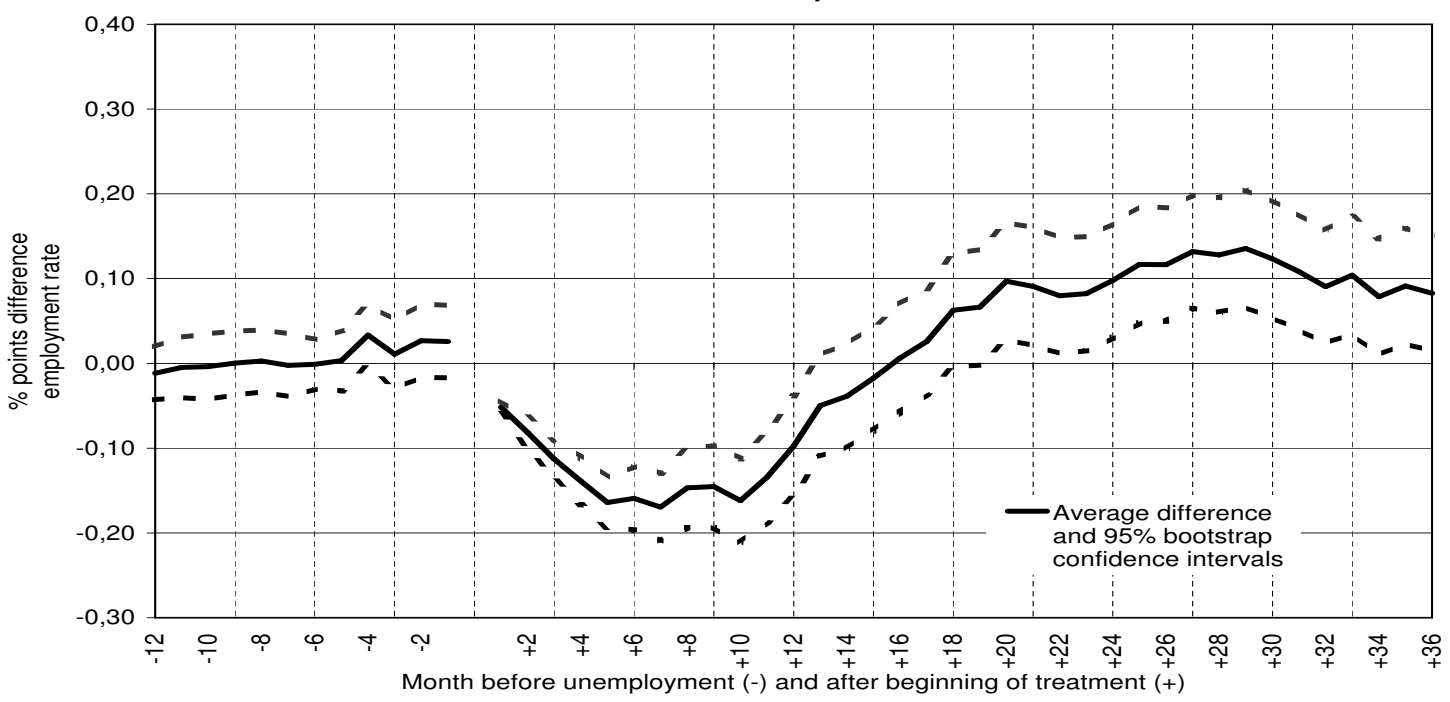

Employment rate for participants in specific skills with previous unemployment 7-12 months, East Germany

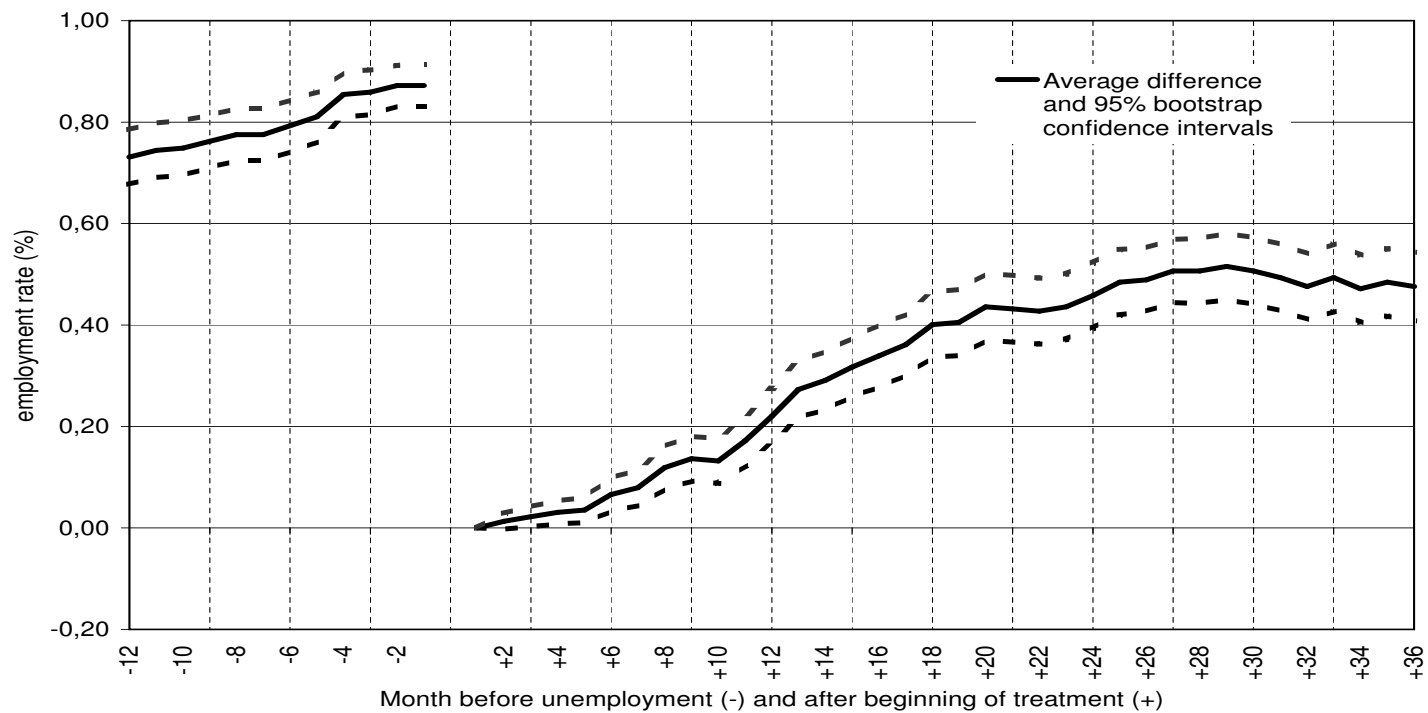

Estimated non-treatment employment for participants in specific skills with previous unemployment 7-12 months, East Germany

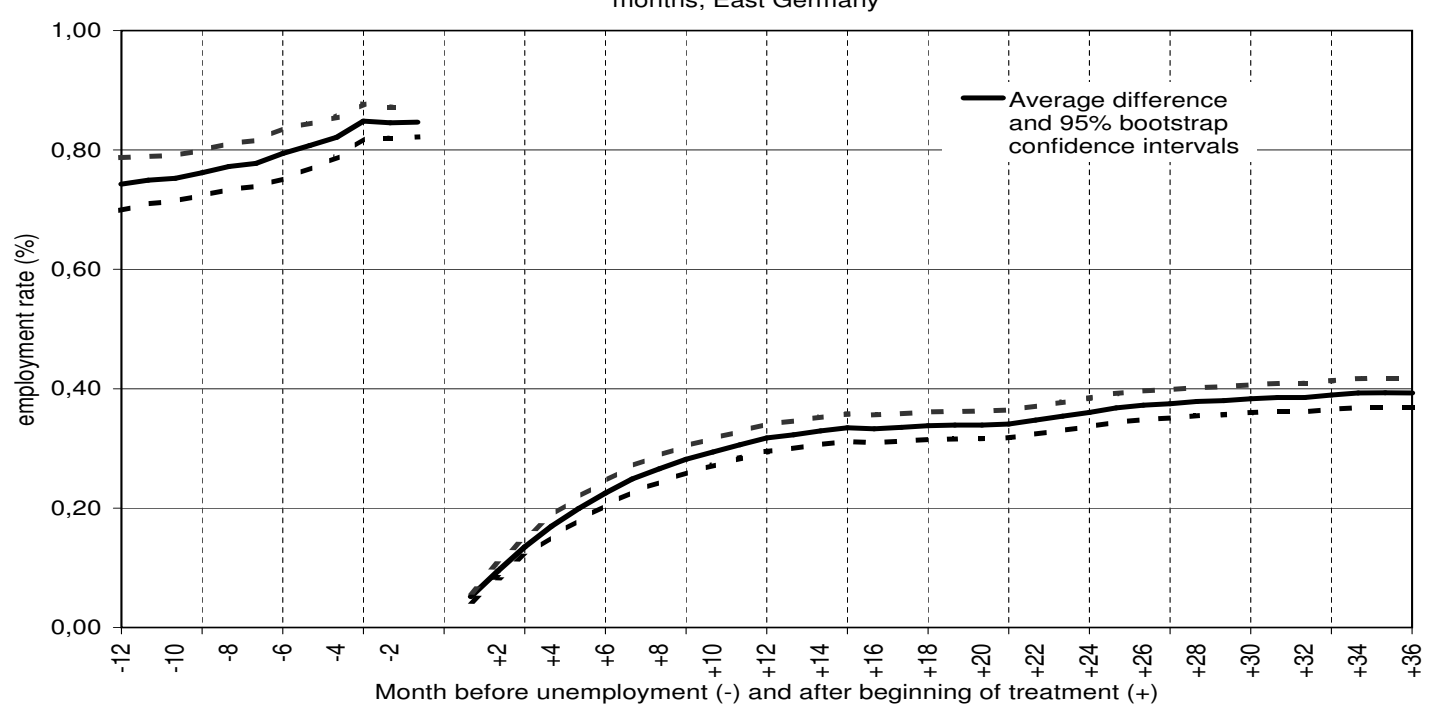


Figure 6: SPST Treatment East Germany months 13-24

Average treatment effect for participants in specific skills with previous unemployment 13-24 months, East Germany

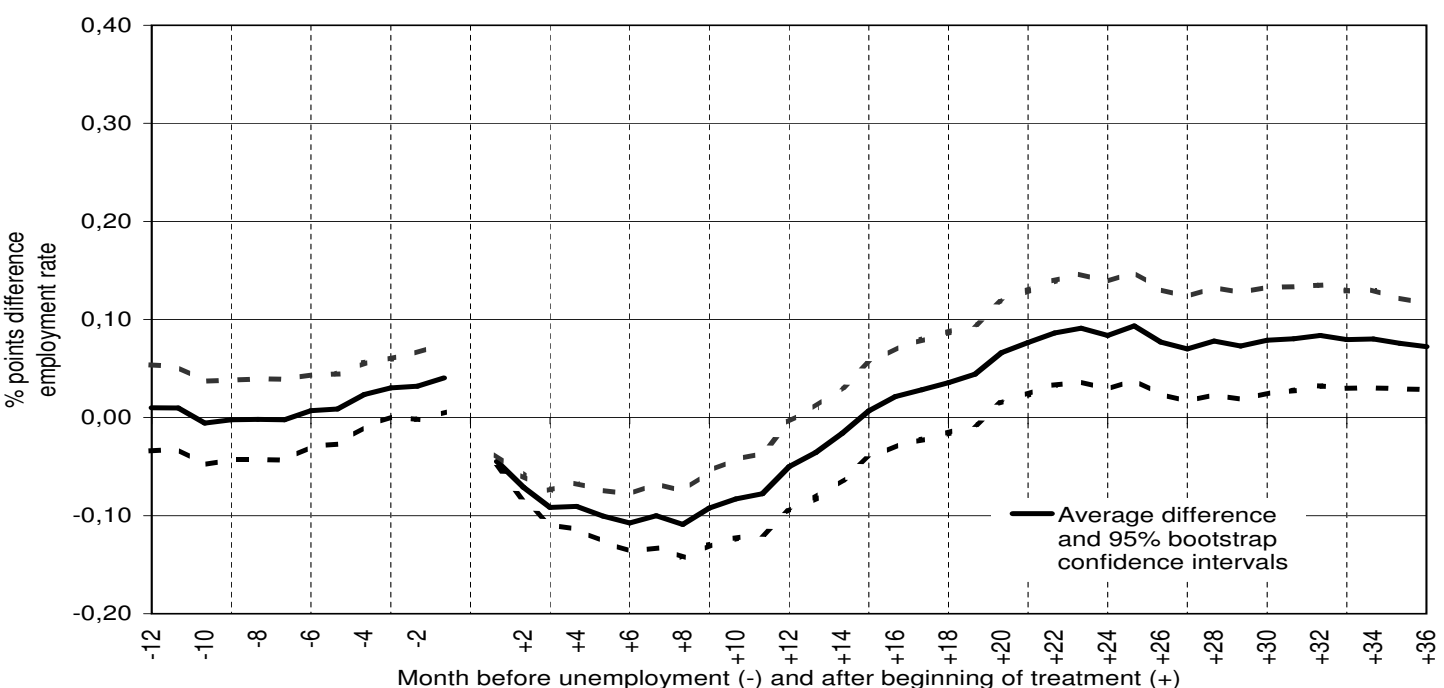

Employment rate for participants in specific skills with previous unemployment 13-24 months, East

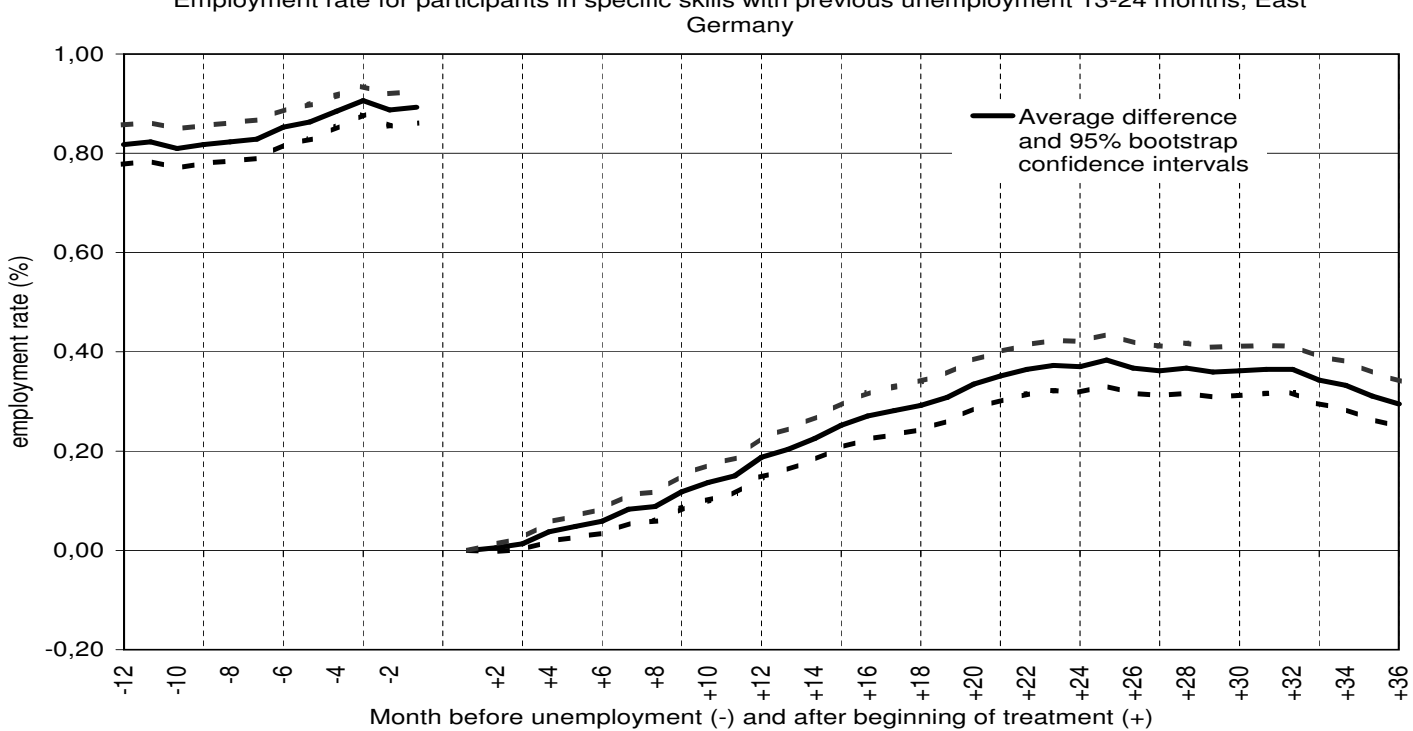

Estimated non-treatment employment for participants in specific skills with previous unemployment 13-24 months, East Germany

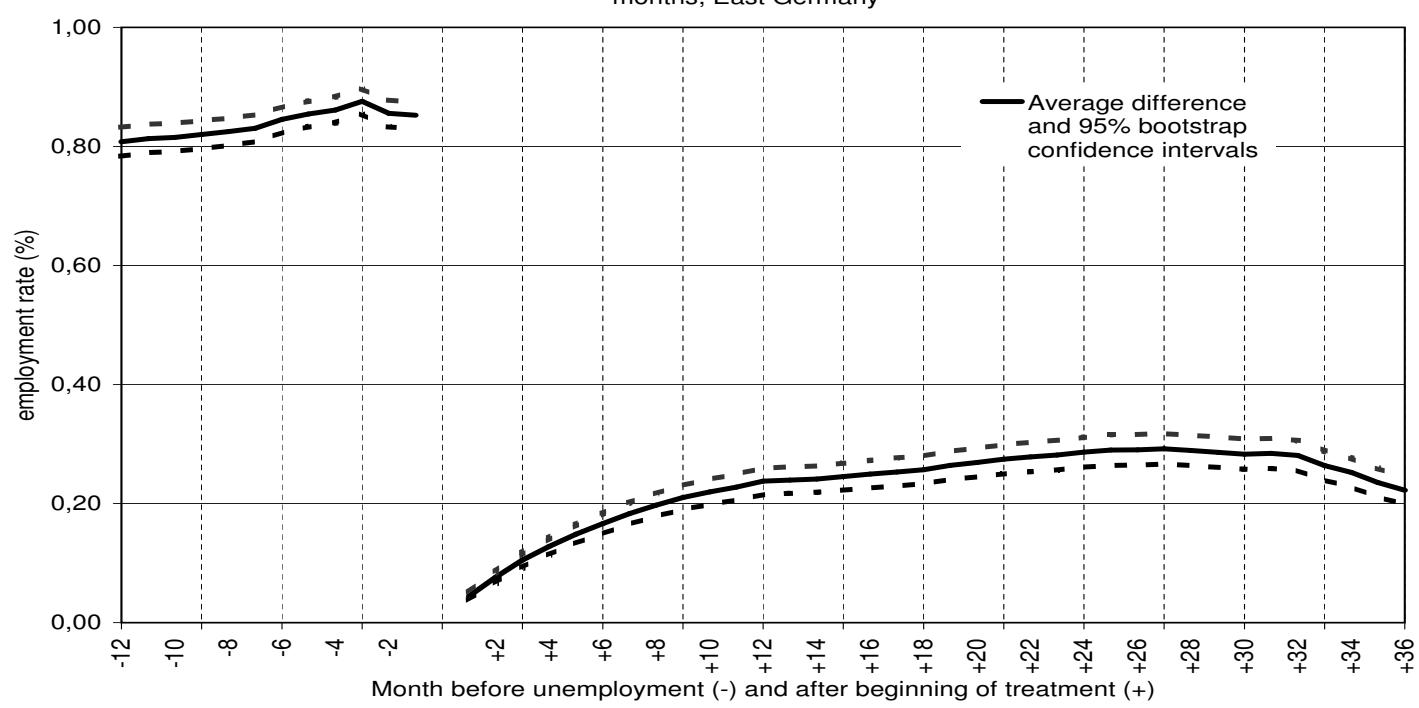




\section{Additional Data Appendix}

\section{Types of further training: A classification}

The basic regulation of further training provides only a very basic framework, but does not define specific treatments with respect to integration targets or for target groups. Very different treatments can be implemented under the same regulation (e.g. training for career advancement or short-term courses for very long-term unemployed are both reported as "further vocational training"). Therefore, earlier decriptive studies ${ }^{1}$ on the types of treatment do not distinguish treatments providing basic social skills or skills preparing the job-search from treatment offering certified professional skills.

As this study uses merged data, we can additionally identify how close the treatment is to a firm specific labor market by exploiting the information from the occupational status variable as well as we can distinguish how specific the training is by using all available information from benefit payments and the type of training variable of the FuU-data. As the training data is partially incomplete, the use of employment data is additionally necessary to identify the full extent of the participation. The combination of these different sources allows us to identify informative (and coherent) types of treatment applying a typology relying on the type of training from FuU-data (see Lechner, Miquel, Wunsch 2003 for an in-depth description of the information provided) and the closeness to internal labor markets as indicated by the IABS-data on employment status.

The combination of both - the employment status and the program information - allows us to identify specific treatments for similar groups. While the program information "further vocational training" might comprise both employed and unemployed participants, the employment status allows additionally to identify the target group ("re-integration" for specific groups or unemployed or "career advancement" for employees) or to indicate how close the program is related to an internal labor market. A combination of training and employment data is therefore considered to be more informative than the unmodified information from the training data, since these do not show the conditions under which this progam is delivered.

We suggest to distinguish seven different types of further training. These treatments differ according to the level of occupational specific skills and closeness to the internal labor market. The following section provides seven different types of further training (referred to as type [a]- [g])

(a) Preparation, social skills and short-term training This type of training provides non-vocational skills in educational institutions or participants are taking part in programs evaluating their problems in finding regular employment (Feststellungsmaßnahmen, § 41a AFG). The training provides skills on a general level and focuses on an improvement of the job search process. In other cases short-term training is implemented as a first stage for continued training, so

\footnotetext{
${ }^{1}$ One of these studies based on the reported FuU-data by Blasche/Nagel (1995) does distinguish whether the training was carried out as an adjustment or a retraining and whether it was a full-time or part-time treatment.
} 
that the programs prepare the participants for another further training (Vorschaltmaßnahmen). In short-term training, the provision of profession specific skills is supposed to be of minor importance and individuals who enter this type of treatment are supposed to lack fundamental general skills and social skills for job search. We assume these treatments not to provide formal certificates or degrees.

(b) Provision of specific professional skills and techniques The objective of this type of further education is the improvement of the starting position in finding a new job by providing additional skills and specific professional knowledge in short-term and medium-term courses. These programs serve to learn or freshen up of single skills, e.g. computer skills or the new operational practises. They are is intended for unemployed or persons at risk of becoming unemployed in order to facilitate integration into full employment.

This type of treatment corresponds to the vast majority of public sector sponsored further training programs and is usually carried out by external educational institutions. Courses provide classroom training and the acquisition of professional knowledge by working experience. In most cases, participants are provided certificates about the courses, signalling refreshed or newly acquired skills and the amount of theory and work-experience achieved. The treatment is specific to the skills of the first vocational training degree and aims at increasing the individual chances of finding new employment within their profession. Compared to the short-term courses above, this type of training is supposed to influence the matching probability of the unemployed with jobs offered because of formal certificates after training.

(c) Qualification via the educational system/retraining This type of training consists of the provision of a new and comprehensive training according to the regulation of the German dual system of vocational training. It is offered to individuals who completed already a first vocational training and face severe difficulties in finding a new employment within their profession. Retraining is formal vocational training into a certified occupation after the end of a first vocational training. It might however also be offered to individuals without a first formal training. Up to 94, this type of treatment is also accessible to individuals without the formal criterion of "necessity" for career advancement. Participants are then granted an income maintenance as a loan.

Qualification via the educational system/retraining provides widely accepted formal certificates according to the vocational training of the German dual system, which consists of both, theoretical training and work experience. The theoretical part of the training takes place in the public education system. The practical part of the program is often carried out in firms providing participants work experience in their field, but sometimes also in training establishments of the institutions providing this type of training. This type of treatment aims at the achievement of a formal job qualification in order to improve the job match.

(d) Training for specific job offers The main objective of this type of training is the provision of specific occupational and social skills to individuals who intend to accept a job offer and to fulfil the formal requirements for the specific job. Training of this type provides specific skills 
and qualification as described under (b). Generally individuals pass through short-term courses with specific professional skills in order to meet the requirements for a job offer. The contents such courses are closely linked to the employment, in which individuals are employed afterwards. Usually courses take place in the training division of companies. Contents of the courses also consist of social, personal and methodological knowledge. Compared to training which offers a certification after the end of a program, this type of training has only little impact on future employment prospects, once the job match with the precise employer is achieved.

(e) Direct integration in the first labor market This type of training aims at integration through wage subsidies according to $\S 49$ AFG. Wage subsidies are paid for the employment of formerly long-term unemployed and are intended to decrease the competitive disadvantage of these recruits for the period of familiarisation with the skill requirement of the job. Individuals receive only practical guidance for the employment according to the requirements of the firm and are not provided certifiable qualifications.

(f) Career advancement subsidy This type of treatment provides training for individuals who are not unemployed or threatened by unemployment, either as a retraining or as a career advancement in a practised profession. This type of training terminates 94. "Qualification for career advancement" works by providing loans to participants. Although not strictly active labor market policy, career advancement was an important part of public sector sponsored further training in the early 90's (and before). In this treatment, participants are enabled to obtain an advanced formal degree in their profession above the level of a qualified occupational training (e.g. B.A. business administration).

(g) Language training Besides further vocational training, language training is also part of the provision of further training in Germany as regulated by the AFG. The encouragement in participation in courses in German is intended to integrate asylum seekers, displaced persons, ethnic Germans and refugees into the labor market. Participants are provided support for an adequate education in language skills to fulfil regular employment.

\section{Identification of treatment and descriptive statistics}

Participation in different types of training can be identified by either LED-data or FuU-data. In the best case, both sources deliver a coherent information about the treatment and one can easily identify the type of treatment from both data sources.

However, due to quality deficiencies in the participation data, many participants might not be recorded in the FuU-data. In this case, the LED-data helps to identify the treatment on the basis of the benefit variable which itself offers very specific information about the treatment. In other cases, we observe individual records 
showing employment in the IABS information and at the same time training in the FuU-data. This is for example the case if the treatment takes place in a firm and individuals are paid a normal salary (e.g. integration subsidy) or if individuals are prepared for precise job offers. Since we have two separate sources of data, we make use of all available information and combine benefit information with participation data in order to identify all participants in the different types. Section 1 of the data appendix describes in details, which variables were required for this. Section 2 of the data appendix describes the precise coding plan.

As can be shown in table 13 of section 3 of the data appendix, many of the treatments would not have been detected or would have been differently coded if there were not combined information of benefit and participation data. In particular,

- participation data is incomplete, so that a number of treatments can only be identified based on the benefit spell.

- participants in training with a simultaneous employment spells do not appear in the benefit data $(\mathrm{N}=20,909)$ and would not have been coded as participants in the absence of the participation data.

Participation figures in all different types of further training for the years 90-97 are shown in table 1 based on individual spells: The most important group consists of the participants in career advancement training amounting to one quarter of all treatment spells. Usually, these persons are employed while participating.

For the types of training besides career advancement as defined above, the most important category is the "provision of specific professional skills"-training on which we will concentrate in the following with 7,463 spells for the 90's. Almost equally important as this program is participation in the retraining program with $13.4 \%$ of all spells and "training for specific jobs" with $15.2 \%$ of all spells. Language training courses are also an essential part of further training, with $12.7 \%$ of all spells. Direct integration and the short-term training programs are less important with around $5 \%$ of all training spells. 
Table 1: Participation in further training by type of treatment

\begin{tabular}{|c|c|c|c|}
\hline & Frequency & ntage & $\begin{array}{l}\text { lated } \\
\text { ntage }\end{array}$ \\
\hline Missing ${ }^{*}$ & 2738 & 5.9 & 5.9 \\
\hline $\begin{array}{l}\text { Preparation, social skills } \\
\text { and short-term training }\end{array}$ & 2379 & 5.1 & 11 \\
\hline Provision of specific professional skills & 7463 & 16 & 27 \\
\hline Integration via education system & 6239 & 13.4 & 40.3 \\
\hline Training for specific jobs & 7102 & 15.2 & 55.5 \\
\hline Direct integration (wage subsidy) & 2254 & 4.8 & 60.4 \\
\hline Career advancement & 12599 & 27 & 87.3 \\
\hline Language training & 5923 & 12.7 & 100 \\
\hline Total & 46715 & 100 & \\
\hline
\end{tabular}

\footnotetext{
* Missing values originate (a) from codes which were obsolete in the 90's but occur nevertheless for unknown reasons, (b) from an illogical combination of short-term training for unemployed and employment at the same time or (c) from employment or unemployment benefit in combination with codes in the participation data that were not supposed to occur in the 90's. See Sections 1 and 2 of the data appendix for an exact description of the coding plan.
}

\section{Identifying further training in merged data}

The subsequent evaluation study is based on social insurance data and on data for training participants:

- The IAB Employment Subsample (IABS) consists of insurance register data for each employee recorded by the German social insurance system. Individuals in dependent employment are usually subject to the mandatory social insurance system. The IABS additionally reports episodes, which individuals spent in unemployment related to benefit payments (see Bender, Haas, Klose 2000).

- The German Employment Service used to report the structure, contents, duration and benefit payment for participants in further training schemes in a monthly survey as a result of internal and external monitoring objectives (FuU-data, see Bender et al. 2004).

The following section describes these underlying data, the problem of creating an integrated evaluation data base, how data are prepared for the subsequent analysis 
and how the information provided by the IABSLED- and the FuU-data were used in order to identify fairly homogeneous treatments in data.

Using the benefit information from the LED-data In the merged data set, we combine the employment and benefit data base provided by the Institute for Employment research (IABS) a second time with the benefit data (LED). As the merged LED-information provides often a number of parallel spells for one IABS spell, it was necessary to match up to three benefit spells to one IABS spell reporting employment or benefit receipt (see Bender et al., 2005, Chap. 3.1).

The merged data consist of the benefit information from the IABS (the variable "original benefit information" [Leistungsart im Original] LA1) and three additional variables indicating parallel benefit reception from the original LED data ("parallel original benefit information 1-3" [Leistungsart im Original 1-3] L1LA1, L2LA1, L3LA1). These four benefit variables offer valuable information about the type of benefit paid by the employment service in case of training which facilitates the identification of the type of treatment: It indicates whether a treatment is carried out under the further training or the retraining regulation and whether the transfer was given for full-time or part-time courses, to participants in language training or as a loan for career advancement training. We can identify types of training as discussed above by using these benefit variables, but also by combining this information with other variables of the IABS (especially the variable of the occupational status) and the merged FuU-participation data (see below).

Type training from FuU-data In this evaluation study one of the most important advantages compared to survey data is the information about the precise type of training. It allows us to identify homogeneous treatments for the evaluation. In the merging process, up to two parallel FuU-spells are merged to one spell of the IABS data because in many cases the FuU-data provided more than one parallel spell. These two parallel spells provide two variables indicating the type of course (Maßnahmeart [FMASART1, FMASART2]).

Combining the information in merged data Participation in training can be identified by either LED-data or FuU-data. In the best case, both sources deliver the same information about the treatment and one can easily identify the type of 
treatment from both data sources. However, due to the quality deficiencies in the participation data many participants are not recorded in the FuU-data. In this case, the LED-data helps to identify the treatment on the basis of the benefit variable which allows the identification of specific treatments. In other cases, we observe individual records showing employment in the IABS information and at the same time training in the FuU-data. This is for example the case if the treatment takes place in a firm and individuals are paid a normal salary (e.g. integration subsidy) or if individuals are prepared for precise job offers.

We take advantage of all information form the three parallel benefit spells, the original benefit information as shown in the IABS and the type of treatment as recorded in the two parallel FuU-spells in order to generate the most precise information available with respect to the type of treatment of either the first, the second or the third spell of the LED data compared to the FuU-data. Using all variables also allows us to identify treatments if one of the sources does not record explicable information about treatment: Often it seems as if individuals were granted unemployment benefit while being in a training program although the legal regulation would imply a receipt of special benefits related to the treatment: At this point again, we use the FuU-data for the identification of the treatment and assume them to be more credible.

Improving the precision of treatment information The following approach was chosen in order to ensure that both the information coming from FuU and LEDdata are taken into consideration in order to obtain the most precise information of the type of training:

- Since types of treatments (Maßnahmeart) are often coded as "other, nonspecified programs"

(FMASART1=12 [Sonstige Anpassungen]) in the FuU-data, we increase the precision of information about the type of treatment by relying on the second parallel information about the type of training: The second FuU-spell is used if the first FuU-spell is coded as "other adjustment" ("Sonstige Anpassungen") and a second spell includes a code different from 12. Such combined information of FMASART1 and FMASART2 is referred to as FMASART* in the following.

- If we observe parallel spells from the LED-data that provide contradictory 
information about the type of benefit paid to the claimant, we identify a treated person when ever one of the three spells of benefit payments provide the information that an income maintenance payment related to training occurred. To put it differently: if the L1LA1-variable indicates unemployment benefit and the second variable (L2LA1) indicates any payment of a training related benefit, then the latter is used for the identification of the treatment status. The aggregated information from the benefit data is referred to as L*LA1.

- If the benefit variables $\mathrm{L}^{*} \mathrm{LA} 1$ show information opposing to a related FuUspell we use the FuU-information in these cases (e.g. benefits for retraining in the LED data in combination with information about "provision of specific professional skills" in the FuU-data). Another example: The benefit information is coded as 310 corresponding to "further education for resettlers or ethnic German" (EGGUF Notwendige Fortbildung bei Aus- und Übersiedlern) and the FMASART* variables specify the treatment as "vocational exam", FMASART* is supposed to be more precise with respect to the type of treatment, and the treatment then will be coded as "integration via the education system".

\section{Coding plan for the treatment information}

\section{Preparation, social skills and short-term training}

(a) If the income maintenance information shows valid codes, "preparation" corresponds to a consolidated type of measure FMASART* if the following program codes in the training data (FUU) appear:

\begin{tabular}{l|l|l}
\begin{tabular}{l|l} 
Program \\
code
\end{tabular} & Label & Label in German \\
\hline \multirow{2}{*}{10} & Training enterprise & Übungsfirma \\
11 & Training studio & Übungswerkstatt \\
13 & Short term training & $\S 41 \mathrm{a}$ \\
20 & Assess-, and preparation courses & $\begin{array}{l}\text { Feststell-, } \\
\text { Vorbereitmaßnahme }\end{array}$ \\
\hline & &
\end{tabular}


(b) If the values of income maintenance payment according to $\S 41 \mathrm{a} A F G$ appear in the income maintenance variables, a participation in "Preparation, social skills and short-term training" is identified if the participation data (FUU) indicate either "missing" or "12 sonst. Anpassung der berufl. Kenntnisse" (other adjustment of working skills) in the same record:

\begin{tabular}{|c|c|c|}
\hline Benefit code & Label & Label in German \\
\hline UHG41A & $\begin{array}{l}\text { Full income maintenance necessary } \\
\text { short-term training }\end{array}$ & $\begin{array}{l}\text { Unterhaltsgeld, notwendige } \S 41 \mathrm{a}, \\
\text { volles Unterhaltsgeld }\end{array}$ \\
\hline EGGUM & $\begin{array}{l}\text { Short-term training for resettlers or } \\
\text { German ethics }\end{array}$ & $\begin{array}{l}\text { EGG bei } \S 41 \mathrm{a} \text { Maßnahme v Aus- } \\
\text { /Übersiedlern }\end{array}$ \\
\hline UHG1M & $\begin{array}{l}\text { Income maintenance ending former } \\
\text { unemployment for short-term train- } \\
\text { ing in } \S 41 \mathrm{a}\end{array}$ & $\begin{array}{l}\text { Unterhaltsgeld bei notwendiger } \S 41 \mathrm{a} \\
\text { wegen vorheriger Arbeitslosigkeit }\end{array}$ \\
\hline UHGMHG & $\begin{array}{l}\text { Income maintenance amounting to } \\
\text { unemployment benefits for neces- } \\
\text { sary short-term training in } \S 41 \mathrm{a}\end{array}$ & $\begin{array}{l}\text { Unterhaltsgeld bei notwendiger } \S 41 \mathrm{a} \\
\text { in Höhe des ALG }\end{array}$ \\
\hline UHGM328 & $\begin{array}{l}\text { Full income maintenance because of } \\
\text { unemployment or in danger of loos- } \\
\text { ing the job for necessary short-term } \\
\text { training in } \S 41 \mathrm{a}\end{array}$ & $\begin{array}{l}\text { Volles Unterhaltsgeld bei notwendi- } \\
\text { ger } \$ 41 \mathrm{a} \text { aufgrund von Arbeit- } \\
\text { slosigkeit oder Bedrohung von Ar- } \\
\text { beitslosigkeit }\end{array}$ \\
\hline UHGMAH & $\begin{array}{l}\text { Income maintenance amounting to } \\
\text { un-employment assistance for neces- } \\
\text { sary short-term training in } \S 41 \mathrm{a}\end{array}$ & $\begin{array}{l}\text { Unterhaltsgeld } \S 41 \mathrm{a} \text { in Höhe der } \\
\text { Arbeitslosenhilfe }\end{array}$ \\
\hline
\end{tabular}

(c) If the income maintenance variables are either missing or have any reasonable value corresponding to employment in the IABSLED-data, then the person is never considered as participating in the "Preparation, social skills and shortterm training" treatment because we do not suppose individuals participation in preparation courses while working. Especially a training information corresponding to "12 sonstige Anpassungen der berufl. Kenntnisse" (other adjustment of working skills) is then not seen as such a treatment, but as a treatment in type b.

\section{Provision of specific professional skills and techniques}

(a) If the income maintenance variables show valid codes, a treatment is considered to be a "provision of specific professional skills" if the information of the type 
of program FMASART* given in the FuU-data shows the coding.

\begin{tabular}{|c|c|c|}
\hline $\begin{array}{l}\text { Program } \\
\text { code }\end{array}$ & Label & Label in German \\
\hline 34 & Basic training & $\begin{array}{l}\text { Grundausbildungslehrgang (before } \\
1986 \text { ) }\end{array}$ \\
\hline 18 & Other training institution & $\begin{array}{l}\text { sonst. Übungs- und Trainingsein- } \\
\text { richtung }\end{array}$ \\
\hline 21 & $\begin{array}{l}\text { Qualification below skilled worker } \\
\text { level }\end{array}$ & $\begin{array}{l}\text { Qualifikation unterhalb des Fachar- } \\
\text { beiterniveaus }\end{array}$ \\
\hline 24 & Practical further education & berufspraktische Fortbildung \\
\hline 31 & $\begin{array}{l}\text { Further education of trainers and } \\
\text { multidisciplinary qualification }\end{array}$ & $\begin{array}{l}\text { Heran-/Fortbildung v. Aus- } \\
\text { bildungskräften/ } \\
\text { feldübergreifende Qualifikation }\end{array}$ \\
\hline
\end{tabular}

(b) In many cases, the incomes maintenance payment indicate that individuals receive unemployment benefits. However, FuU-data may suggest that training occurred at the same time by indicating "other adjustment of working skills" ("sonst. Anpassung der berufl. Kenntnisse") because programs can also be taken during unemployment. In this case, we assume that persons participate in courses which provide only specific professional skills. So the exact condition of this treatment is a coding of FMASART* to this type of treatment and a parallel transfer payment as documented below:

\begin{tabular}{l|l|l}
$\begin{array}{l}\text { Program } \\
\text { code }\end{array}$ & Label & Label in German \\
\hline 12 & Other adjustment of working skills & $\begin{array}{l}\text { sonst. Anpassung der berufl. } \\
\text { Kenntnisse }\end{array}$ \\
\hline
\end{tabular}

If this information corresponds to one of the following transfer payments the type of treatment is identified as "provision of specific professional skills".

\begin{tabular}{|c|c|c|}
\hline Benefit code & Label & Label in German \\
\hline ALGEH & $\begin{array}{l}\text { Unemployment benefits for former } \\
\text { development aid volunteers }\end{array}$ & $\begin{array}{l}\text { Arbeitslosengeld für ehemalige En- } \\
\text { twicklungshelfer }\end{array}$ \\
\hline ALG101 & Regular unemployment benefits & Arbeitslosengeld Code 101 \\
\hline
\end{tabular}




\begin{tabular}{|c|c|c|}
\hline Benefit code & Label & German \\
\hline ALGI & $\begin{array}{l}\text { Regular unemployment benefits and } \\
\text { unemployment benefits for home } \\
\text { comers }\end{array}$ & $\begin{array}{l}\text { Arbeitslosengeld und Arbeitslosen- } \\
\text { geld für Heimkehrer }\end{array}$ \\
\hline ALBSZ & $\begin{array}{l}\text { Unemployment assistance for tem- } \\
\text { porary soldiers }\end{array}$ & $\begin{array}{l}\text { Arbeitslosenhilfe für Soldaten auf } \\
\text { Zeit }\end{array}$ \\
\hline HKA & $\begin{array}{l}\text { Unemployment benefits for home } \\
\text { comers }\end{array}$ & Arbeitslosengeld für Heimkehrer \\
\hline ALGHU & $\begin{array}{l}\text { Unemployment benefits for political } \\
\text { prisoners subject to } \S 249 \mathrm{~g}\end{array}$ & $\begin{array}{l}\text { Arbeitslosengeld für polit. Häftlinge } \\
\text { gem. } § 249 \mathrm{~g}\end{array}$ \\
\hline ALB7 & $\begin{array}{l}\text { Unemployment assistance for former } \\
\text { development aid volunteers }\end{array}$ & $\begin{array}{l}\text { Arbeitslosenhilfe für ehem. En- } \\
\text { twicklungshelfer }\end{array}$ \\
\hline EGGA & $\begin{array}{l}\text { Benefits in case of language educa- } \\
\text { tion }\end{array}$ & $\begin{array}{l}\text { Eingliederungsgeld für Aus- } \\
\text { /Übersiedler bei Arbeitslosigkeit }\end{array}$ \\
\hline ALUEG & $\begin{array}{l}\text { Benefits to bridge the time to retire- } \\
\text { ment pension subject }\end{array}$ & Altersübergangsgeld \\
\hline EGHI & $\begin{array}{l}\text { Assistance in case of language edu- } \\
\text { cation }\end{array}$ & $\begin{array}{l}\text { Eingliederungshilfe bei Arbeit- } \\
\text { slosigkeit oder Sprachkurs für } \\
\text { Spätaussiedler }\end{array}$ \\
\hline DLUEG & $\begin{array}{l}\text { Benefits/transfers to bridge the time } \\
\text { to retirement pension paid by BA }\end{array}$ & $\begin{array}{l}\text { Altersübergangsgeld- Ausgleichsbe- } \\
\text { trag von BA }\end{array}$ \\
\hline DLUEGB & $\begin{array}{l}\text { Benefits/transfers to bridge the time } \\
\text { to retirement pension paid by Fed- } \\
\text { eral Ministry }\end{array}$ & $\begin{array}{l}\text { Altersübergangsgeld- Ausgleichsbe- } \\
\text { trag Bund }\end{array}$ \\
\hline ALUEGV & $\begin{array}{l}\text { Benefits to bridge the time to retire- } \\
\text { ment pension for former recipients of } \\
\text { early retirement payments }\end{array}$ & $\begin{array}{l}\text { Altersübergangsgeld für ehem. } \\
\text { Bezieher von Vorruhestandsgeld }\end{array}$ \\
\hline ALUEGS & $\begin{array}{l}\text { Benefits to bridge the time to retire- } \\
\text { ment pension for independent work- } \\
\text { ers }\end{array}$ & $\begin{array}{l}\text { Altersübergangsgeld für Selb- } \\
\text { stständige }\end{array}$ \\
\hline ALUEGH & $\begin{array}{l}\text { Benefits to bridge the time to re- } \\
\text { tirement pension for former prison- } \\
\text { ers and hindered persons }\end{array}$ & $\begin{array}{l}\text { Altersübergangsgeld für ehem. } \\
\text { Häftlinge u. verhinderte Arbeit- } \\
\text { nehmer }\end{array}$ \\
\hline ALUEGF & $\begin{array}{l}\text { Benefits to bridge the time to retire- } \\
\text { ment pension for former recipients of } \\
\text { early retirement payments as of the } \\
833 \text { rd day }\end{array}$ & $\begin{array}{l}\text { Altersübergangsgeld für ehem. } \\
\text { Bezieher von Vorruhestandsgeld ab } \\
\text { dem } 833 \text { Tag }\end{array}$ \\
\hline ALUEGB & $\begin{array}{l}\text { Benefits to bridge the time to retire- } \\
\text { ment pension as of the } 833 \mathrm{rd} \text { day }\end{array}$ & $\begin{array}{l}\text { Altersübergangsgeld ab dem } 833 \text {. } \\
\text { Tag }\end{array}$ \\
\hline ALG118 & $\begin{array}{l}\text { Regular unemployment benefits } \\
\text { code } 118\end{array}$ & Arbeitslosengeld Code 118 \\
\hline
\end{tabular}

Continued on next page 


\begin{tabular}{|c|c|c|}
\hline Benefit code & Label & Label in German \\
\hline ALG & $\begin{array}{l}\text { Regular unemployment benefits } \\
\text { code } 119\end{array}$ & Arbeitslosengeld Code 119 \\
\hline ATGALG & Regular unemployment benefits & Arbeitslosengeld (andere) \\
\hline ATGAUF & Regular unemployment benefits & Arbeitslosengeld (andere) \\
\hline ALHIA & $\begin{array}{l}\text { Unemployment assistance which fol- } \\
\text { lows unemployment benefits }\end{array}$ & $\begin{array}{l}\text { Anschlussarbeitslosenhilfe an Ar- } \\
\text { beitslosengeld }\end{array}$ \\
\hline ALHIB & $\begin{array}{l}\text { Original unemployment assistance, } \\
\text { no claim for unemployment benefits }\end{array}$ & $\begin{array}{l}\text { Originäre Arbeitslosenhilfe (kein } \\
\text { Anspruch auf Arbeitslosengeld) }\end{array}$ \\
\hline ALHIEH & $\begin{array}{l}\text { Unemployment assistance for former } \\
\text { development aid volunteers }\end{array}$ & $\begin{array}{l}\text { Arbeitslosenhilfe für ehem. En- } \\
\text { twicklungshelfer }\end{array}$ \\
\hline ALB8 & $\begin{array}{l}\text { Unemployment assistance which fol- } \\
\text { lows unemployment benefits for for- } \\
\text { mer development aid volunteers }\end{array}$ & $\begin{array}{l}\text { Anschlussarbeitslosenhilfe an Ar- } \\
\text { beitslosenhilfe nur für Entwicklung- } \\
\text { shelfer }\end{array}$ \\
\hline $\mathrm{RV}$ & Advanced pension payment & Rentenvorschuss \\
\hline ALHISZ & $\begin{array}{l}\text { Unemployment assistance for tem- } \\
\text { porary soldiers }\end{array}$ & $\begin{array}{l}\text { Arbeitslosenhilfe für Soldaten auf } \\
\text { Zeit }\end{array}$ \\
\hline ALHIHU & $\begin{array}{l}\text { Unemployment assistance for politi- } \\
\text { cal prisoners subject to } \S 249 \mathrm{~g}\end{array}$ & $\begin{array}{lcc}\text { Arbeitslosenhilfe } & \text { für } & \text { ehem. } \\
\text { Häftlinge u. } & \text { verhinderte Ar- } \\
\text { beitnehmer nach } & \text { A } 249 \mathrm{~g} \text { AFG }\end{array}$ \\
\hline
\end{tabular}

(c) If the FuU-data show a missing value or "12 sonstige Anpassung der berufl. Kenntnisse" (other adjustment of working skills) and the income maintenance variables indicate the following values, treatment were identified to be of the specific professional skills-type:

\section{Qualification for the first labor market via the education system}

(a) If the income maintenance variables show valid codes (no missing) in case of the following programs from the FuU-data, the type of treatment is recoded to a "Qualification via the educational system/retraining".

\begin{tabular}{l|l|l}
$\begin{array}{l}\text { Program } \\
\text { code }\end{array}$ & Label & Label in German \\
\hline 29 & Certification & berufl. Abschlussprüfung \\
32 & Retraining & Umschulung \\
\hline & \multicolumn{2}{l}{}
\end{tabular}




\begin{tabular}{|c|c|c|}
\hline Benefit code & Label & Label in German \\
\hline EGGUF & $\begin{array}{l}\text { Benefits in case of further education } \\
\text { for resettlers or German Ethics }\end{array}$ & $\begin{array}{l}\text { Eingliederungsgeld bei notwendiger } \\
\text { Fortbildung von Aus-/Übersiedlern }\end{array}$ \\
\hline UHGTF & $\begin{array}{l}\text { Income maintenance in case of part } \\
\text { time further education } 44 \mathrm{IIb}\end{array}$ & $\begin{array}{l}\text { Unterhaltsgeld bei Teilzeitfortbil- } \\
\text { dung } 44 \text { II b }\end{array}$ \\
\hline UHGFAG & $\begin{array}{l}\text { Income maintenance for further ed- } \\
\text { ucation, unemployment and condi- } \\
\text { tions for income maintenance not } \\
\text { met, income maintenance amount- } \\
\text { ing to unemployment benefits is } \\
\text { paid }\end{array}$ & $\begin{array}{l}\text { Unterhaltsgeld bei Fortbildung, Ar- } \\
\text { beitslosigkeit, Zeiten für Unterhalts- } \\
\text { geld nicht erfüllt, Unter-haltsgeld in } \\
\text { Höhe der Arbeitslosenhilfe }\end{array}$ \\
\hline UHGF & $\begin{array}{l}\text { Income maintenance for necessary } \\
\text { further education for unemployed } \\
\text { persons or persons whose jobs are in } \\
\text { danger }\end{array}$ & $\begin{array}{l}\text { Unterhaltsgeld } \text { bei notwendi- } \\
\text { ger Fortbildung } \\
\text { bedroht) }\end{array}$ \\
\hline UHGEH335 & $\begin{array}{l}\text { Income maintenance for develop- } \\
\text { ment aid volunteers in further edu- } \\
\text { cation measures code } 335\end{array}$ & $\begin{array}{l}\text { Unterhaltsgeld für Entwicklung- } \\
\text { shelfer notwendiger Fortbildung } \\
\text { (arbeitslos oder bedroht) }\end{array}$ \\
\hline UHGF4 & $\begin{array}{l}\text { Complete income maintenance for } \\
\text { further education due to unemploy- } \\
\text { ment }\end{array}$ & $\begin{array}{l}\text { volles Unterhaltsgeld bei notw. } \\
\text { Fortbildung wegen Arbeitslosigkeit }\end{array}$ \\
\hline UHGTF4 & $\begin{array}{l}\text { Income maintenance because of nec- } \\
\text { essary part time further education } \\
\text { due to danger of loosing the job as } \\
\text { of } 1.1 .94\end{array}$ & $\begin{array}{l}\text { Unterhaltsgeld bei notw. TZ- } \\
\text { Fortbild wegen Bedrohung von Ar- } \\
\text { beitslosigkeit oder Berufsabschluss } \\
\text { ab } 1.1 .94\end{array}$ \\
\hline UHGEH4 & $\begin{array}{l}\text { Income maintenance for unem- } \\
\text { ployed development aid volunteers } \\
\text { as of } 94\end{array}$ & $\begin{array}{l}\text { Unterhaltsgeld für Entwicklung- } \\
\text { shelfer notwendiger Fortbildung } \\
\text { (arbeitslos oder bedroht) ab } 1994\end{array}$ \\
\hline UHGFA4 & $\begin{array}{l}\text { Income maintenance amounting to } \\
\text { unemployment assistance because of } \\
\text { necessary further education due to } \\
\text { unemployment or danger of loosing } \\
\text { the job as of } 1.1 .94\end{array}$ & $\begin{array}{l}\text { Unterhaltsgeld in Höhe der Arbeit- } \\
\text { slosenhilfe bei notw. Fortbildung } \\
\text { wegen Arbeitslosigkeit ab } 1994\end{array}$ \\
\hline
\end{tabular}

(b) In case of a missing of the benefit information indicating that participants are employed while preparing for a vocational exam or attending a retraining, the treatment is also coded to a qualification for the first labor market via the education system if the FuU-data shows the following codes: 


\begin{tabular}{l|l|l}
$\begin{array}{l}\text { Program } \\
\text { code }\end{array}$ & Label & Label in German \\
\hline 29 & Certification & berufl. Abschlussprüfung \\
32 & Retraining & Umschulung \\
\hline
\end{tabular}

(c) If the FuU-data shows a missing value or a treatment "other type of treatment" (12 sonstige Anpassung der berufl. Kenntnisse), but the benefit variables indicate one of the following codes referring to the receipt of subsistence during a retraining course, the treatment is considered to be a qualification for the first labor market via the education system:

\begin{tabular}{|c|c|c|}
\hline Benefit code & Label & Label in German \\
\hline UHGTU & $\begin{array}{l}\text { Income maintenance for part time } \\
\text { jobs and retraining }\end{array}$ & $\begin{array}{l}\text { Unterhaltsgeld bei Teilzeit und Um- } \\
\text { schulung }\end{array}$ \\
\hline EGGUU & $\begin{array}{l}\text { Benefits in case of necessary further } \\
\text { education for re-settlers or German } \\
\text { Ethics }\end{array}$ & $\begin{array}{l}\text { Eingliederungsgeld bei notwendiger } \\
\text { Umschulung von Aus-/Übersiedlern }\end{array}$ \\
\hline UHGU & $\begin{array}{l}\text { Income maintenance in case of re- } \\
\text { training of unemployed persons or } \\
\text { persons whose jobs are in danger }\end{array}$ & $\begin{array}{l}\text { Unterhaltsgeld bei notwendiger } \\
\text { Umschulung wegen Arbeitslosigkeit } \\
\text { oder Bedrohung }\end{array}$ \\
\hline UHGUAG & $\begin{array}{l}\text { Income maintenance amounting to } \\
\text { unemployment benefits because of } \\
\text { retraining of former unemployed } \\
\text { persons }\end{array}$ & $\begin{array}{l}\text { Unterhaltsgeld in Höhe des Arbeit- } \\
\text { slosengeldes bei Umschulung und } \\
\text { vorheriger Arbeitslosigkeit }\end{array}$ \\
\hline UHGUAH & $\begin{array}{l}\text { Income maintenance amounting to } \\
\text { unemployment assistance because } \\
\text { of retraining of former unemployed } \\
\text { persons }\end{array}$ & $\begin{array}{l}\text { Unterhaltsgeld in Höhe der Ar- } \\
\text { beitslosenhilfe bei Umschulung und } \\
\text { vorheriger Arbeitslosigkeit }\end{array}$ \\
\hline UGHU4 & $\begin{array}{l}\text { Income maintenance for necessary } \\
\text { retaining of persons whose jobs are } \\
\text { in danger or vocational exam as of } \\
1.1 .94\end{array}$ & $\begin{array}{l}\text { Unterhaltsgeld bei notwendiger Um- } \\
\text { schulung wegen Bedrohung von Ar- } \\
\text { beitslosigkeit oder Berufsabschluss } \\
\text { ab } 1994\end{array}$ \\
\hline UHGTU4 & $\begin{array}{l}\text { Income maintenance for necessary } \\
\text { part-time retaining of persons whose } \\
\text { jobs are in danger or vocational } \\
\text { exam as of } 1.1 .94\end{array}$ & $\begin{array}{l}\text { Teilzeit-Unterhaltsgeld bei } \\
\text { notwendiger Umschulung wegen } \\
\text { Bedrohung von Arbeitslosigkeit } \\
\text { oder Berufsabschluss ab } 1995\end{array}$ \\
\hline UHGUA4 & $\begin{array}{l}\text { Income maintenance amounting to } \\
\text { unemployment assistance in case of } \\
\text { retraining due to unemployment as } \\
\text { of } 1.1 .94\end{array}$ & $\begin{array}{l}\text { Unterhaltsgeld in Höhe der Ar- } \\
\text { beitslosenhilfe bei notwendiger Um- } \\
\text { schlung aus Arbeitslosigkeit, ab } \\
1994\end{array}$ \\
\hline
\end{tabular}




\section{Training for precise job offers}

(a) Given that the variable BTYP indicates that individuals are in employment and that the parallel benefit variable has no valid code, we expect these individuals to prepare themselves for a precise jobs in a firm if the type of treatment in the $\mathrm{FuU}$-data shows the following codes:

\begin{tabular}{l|l|l}
$\begin{array}{l}\text { Program } \\
\text { code }\end{array}$ & Label & Label in German \\
\hline 10 & $\begin{array}{l}\text { Training enterprise } \\
\text { Training studio } \\
\text { Other adjustment of working skills } \\
11\end{array}$ & $\begin{array}{l}\text { Übungsfirma } \\
\text { Übungswerkstatt } \\
\text { sonst. Anpassung der berufl. Ken- } \\
\text { Further education of trainers and } \\
\text { multidisciplinary qualification } \\
\text { Other training center }\end{array}$ \\
$\begin{array}{ll}\text { Heran-/Fortb. vus- } \\
\text { bild.kräften/berufsfeldübergr.Qualif. } \\
\text { sonst. Übungs- und Trainingsein- } \\
\text { inchtung } \\
21\end{array}$ & $\begin{array}{l}\text { Qualification below skilled worker } \\
\text { level } \\
\text { Practical further education } \\
\text { niveau unterhalb Facharbeiter- } \\
\text { berufspraktische Fortbildung }\end{array}$ \\
\hline
\end{tabular}

\section{Direct Integration in the first labor market}

(a) Familiarization into regular employment can be supported by a wage subsidy ("direct integration"), so that we only observe regular employment and no income maintenance payments in the data. Treatment is then identified by the FuU-data. Therefore we identify "direct integration" only from the aggregated FMASRT-variables if they are coded by:

\begin{tabular}{l|l|l}
$\begin{array}{l}\text { Program } \\
\text { code }\end{array}$ & Label & Label in German \\
\hline 33 & Integration & Einarbeitung \\
\hline
\end{tabular}

\section{Career advancement training}

(a) "Career advancement training" is often implemented simultaneously to a regular employment. Hence the treatment variables FMASART* in the FuU-data should contain one of the following: 


\begin{tabular}{l|l|l}
$\begin{array}{l}\text { Program } \\
\text { code }\end{array}$ & Label & Label in German \\
\hline 14 & Foreman & Industriemeister $(<97)$ \\
15 & Master craftsman & Handwerksmeister $(<97)$ \\
16 & Other master & sonstiger Meister $(<97)$ \\
26 & Technician & Techniker $(<97)$ \\
27 & Master of business administration & Betriebswirt $(<97)$ \\
28 & Other promotion & sonstiger Aufstieg $(<97)$ \\
17 & Qualification for promotion & Aufstiegsfortbildung (nur 97) \\
\hline
\end{tabular}

(b) If the benefit information exhibits the following values which refer to income maintenance during a career advancement training and if the FuU-data show a missing or "other adjustment of working skills" (12 sonstige Anpassung der beruflichen Kenntnisse), then we identify a career advancement if the benefit information shows one of the following values (including a retraining which implemented as a career advancement training financed by a loan):

\begin{tabular}{l|l|l} 
Benefit code & Label & Label in German \\
\hline UHGDF & $\begin{array}{l}\text { Income maintenance paid as loan for } \\
\text { advisable further education } \\
\text { Uncome maintenance paid as loan for } \\
\text { advisable retraining } \\
\text { Income maintenance paid as loan for } \\
\text { advisable further education of devel- } \\
\text { opment aid volunteer }\end{array}$ & $\begin{array}{l}\text { Unterhaltsgeld als Darlehen bei } \\
\text { zweckmäßiger Fortbildung } \\
\text { Unterhaltsgeld als Darlehen bei } \\
\text { Uneckmäßiger Umschulung } \\
\text { Unterhaltsgeld als Darlehen bei } \\
\text { Entwicklungshelfern }\end{array}$ \\
\hline
\end{tabular}

\section{Language training}

(a) If the benefit information shows any valid code (no missing) and the treatment information from the FuU-data provides information that these individuals pass through a language training, then treatment is identified as a language training:

\begin{tabular}{l|l|l}
$\begin{array}{l}\text { Program } \\
\text { code }\end{array}$ & Label & Label in German \\
\hline 35 & Language training & Deutschlehrgang \\
\hline
\end{tabular}


(b) If the benefit information is missing because individuals are regularly employed while taking part in the training, the treatment is identified to be a language training if the FuU-data provide the following treatment information:

\begin{tabular}{l|l|l}
$\begin{array}{l}\text { Program } \\
\text { code }\end{array}$ & Label & Label in German \\
\hline 35 & Language training & Deutschlehrgang \\
\hline
\end{tabular}

(c) If the FuU-data do not provide a valid code for treatment or indicate that individuals participated in "other adjustment of working skills" (12 sonst. Anpassung der berufl. Kenntnisse), but the benefit information indicates clearly that benefit was paid for language training as indicated by the codes displayed below, the treatment is identified as a language training.

\begin{tabular}{|c|c|c|}
\hline Benefit code & Label & Label in German \\
\hline EGHI & $\begin{array}{l}\text { Assistance in case of unemployment } \\
\text { or language course for resettlers or } \\
\text { German Ethics }\end{array}$ & $\begin{array}{l}\text { Eingliederungshilfe bei Arbeit- } \\
\text { slosigkeit oder Sprachkurs für } \\
\text { Spätaussiedler }\end{array}$ \\
\hline UHGVAK & $\begin{array}{l}\text { Income maintenance in case of lan- } \\
\text { guage courses for asylum seekers and } \\
\text { refugees }\end{array}$ & $\begin{array}{l}\text { Unterhaltsgeld bei Sprachlehrgang } \\
\text { für Asylberechtigte und Kontin- } \\
\text { gentflüchtlinge }\end{array}$ \\
\hline UHGVA & $\begin{array}{l}\text { Income maintenance in case of lan- } \\
\text { guage courses for German Ethic or } \\
\text { recipients of welcome benefits }\end{array}$ & $\begin{array}{l}\text { Unterhaltsgeld für Aussiedler u } \\
\text { Begrüßungsgabeempfänger bei } \\
\text { Sprachlehrgang }\end{array}$ \\
\hline EGHIS & Other benefit for resettlers & andere Eingliederungsgeld \\
\hline EGGSA & $\begin{array}{l}\text { Benefits in case of full-time lan- } \\
\text { guage courses for resettlers or Ger- } \\
\text { man Ethics }\end{array}$ & $\begin{array}{llr}\text { Eingliederungsgeld } & \text { bei } & \text { Vollzeit- } \\
\text { Sprachlehrgängen } & \text { für } & \text { Aus-/ } \\
\text { Übersiedler } & & \end{array}$ \\
\hline EGC & $\begin{array}{l}\text { Benefits in case of part-time lan- } \\
\text { guage courses for resettlers or Ger- } \\
\text { man Ethics }\end{array}$ & $\begin{array}{l}\text { Eingliederungsgeld bei Teilzeit- } \\
\text { Sprachlehrg für Aus-/Übersiedler }\end{array}$ \\
\hline EG & $\begin{array}{l}\text { Benefits in case of full time lan- } \\
\text { guage courses for asylum seekers and } \\
\text { refugees }\end{array}$ & $\begin{array}{lll}\text { Eingliederungsgeld } & \text { bei } & \text { Vol- } \\
\text { lzeitsprachlehrg. } & \text { für } & \text { Kontin- } \\
\text { gentflüchtlinge oder } & \text { Asylbewerber }\end{array}$ \\
\hline EGGSTK & $\begin{array}{l}\text { Benefits in case of full time lan- } \\
\text { guage courses for asylum seekers and } \\
\text { refugees }\end{array}$ & $\begin{array}{lll}\text { Eingliederungsgeld } & \text { bei } & \text { Teilzeit- } \\
\text { sprachlehrg. } & \text { für } & \text { Kontin- } \\
\text { gentflüchtlinge oder } & \text { Asylbewerber }\end{array}$ \\
\hline
\end{tabular}




\section{Types of training and benefit payments}

Table 3 describes the relationship between type of treatment (a) - (g) as defined above and the benefit payment related to treatment for the period 90-7 based on spell data of the merged IABSLED-FuU-data: The types of training are displayed in columns and the benefit information coming from the IABSLED-data in rows. The benefit information is subdivided into several target specific benefit payments. First, we observe quite a substantial number of participants receive unemployment benefit or unemployment assistance while being in further training (indicated by the FuU-data): especially participants in career advancement, short-term training and specific skills-training are receiving unemployment benefit at the time of treatment. Without merging IABSLED to FuU-data, these individuals would not have been identified in the data as participants according to the benefit information implying a structural underestimation of the participation in training.

The next part of table 3 shows in which type of training individuals participate if the benefit information refers to payments for resettlers, German ethnics and refugees. In most cases, these benefits are granted to participants in language courses as expected. However, we also find a substantial number of participants in either the career advancement or the specific skills training.

In case of benefit payments related to short-term training, individuals mainly participate in this type of training, but also to a substantial fraction in retraining and career advancement schemes. If individuals receive income maintenance related to retraining or further vocational training, we observe that many of these individuals also participate in other types of training, e.g. career advancement.

Table 3: Type of treatment and benefit ${ }^{* *}$ payment

\begin{tabular}{|c|c|c|c|c|c|c|c|c|c|}
\hline \multicolumn{10}{|c|}{ Type of training } \\
\hline $\begin{array}{l}\text { information of } \\
\text { income mainte- } \\
\text { nance payment }\end{array}$ & Missing ${ }^{*}$ & $\begin{array}{l}\text { Preparation, } \\
\text { social } \\
\text { skills and } \\
\text { short term } \\
\text { training } \\
\text { (a) }\end{array}$ & $\begin{array}{l}\text { Specific } \\
\text { job } \\
\text { knowl- } \\
\text { edge } \\
\text { (b) }\end{array}$ & $\begin{array}{l}\text { First } \\
\text { labor } \\
\text { market } \\
\text { edu- } \\
\text { cation } \\
\text { system } \\
\text { (c) }\end{array}$ & $\begin{array}{l}\text { Precise } \\
\text { jobs (d) }\end{array}$ & $\begin{array}{l}\text { Direct in- } \\
\text { tegration } \\
\text { (e) }\end{array}$ & $\begin{array}{l}\text { Career } \\
\text { advance- } \\
\text { ment } \\
\text { (f) }\end{array}$ & $\begin{array}{l}\text { Language } \\
\text { training } \\
(\mathrm{g})\end{array}$ & Total \\
\hline $\begin{array}{l}\text { Match of } \\
\text { FuU-data and } \\
\text { benefit infor- } \\
\text { mation was not } \\
\text { achieved }^{* * *}\end{array}$ & 1430 & & & 1746 & 7102 & 2172 & 8209 & 232 & 20909 \\
\hline
\end{tabular}


Type of training

\begin{tabular}{|c|c|c|c|c|c|c|c|c|c|}
\hline $\begin{array}{l}\text { information of } \\
\text { income mainte- } \\
\text { nance payment }\end{array}$ & Missing ${ }^{*}$ & $\begin{array}{l}\text { Preparation } \\
\text { social } \\
\text { skills and } \\
\text { short term } \\
\text { training } \\
\text { (a) }\end{array}$ & $\begin{array}{l}\text {,Specific } \\
\text { job } \\
\text { knowl- } \\
\text { edge } \\
\text { (b) }\end{array}$ & $\begin{array}{l}\text { First } \\
\text { labor } \\
\text { market } \\
\text { edu- } \\
\text { cation } \\
\text { system } \\
\text { (c) }\end{array}$ & $\begin{array}{l}\text { Precise } \\
\text { jobs }(\mathrm{d})\end{array}$ & $\begin{array}{l}\text { Direct in- } \\
\text { tegration } \\
\text { (e) }\end{array}$ & $\begin{array}{l}\text { Career } \\
\text { advance- } \\
\text { ment } \\
\text { (f) }\end{array}$ & $\begin{array}{l}\text { Language } \\
\text { training } \\
(\mathrm{g})\end{array}$ & Total \\
\hline
\end{tabular}

\begin{tabular}{|c|c|c|c|c|c|c|c|c|}
\hline $\begin{array}{l}\text { Regular unem- } \\
\text { ployment bene- } \\
\text { fits }\end{array}$ & 9 & 254 & 551 & 135 & 49 & 345 & 7 & 1350 \\
\hline $\begin{array}{l}\text { Unemployment } \\
\text { assistance } \\
\text { which follows } \\
\text { unemployment } \\
\text { benefits }\end{array}$ & 2 & 318 & 202 & 65 & 8 & 146 & 2 & 743 \\
\hline
\end{tabular}

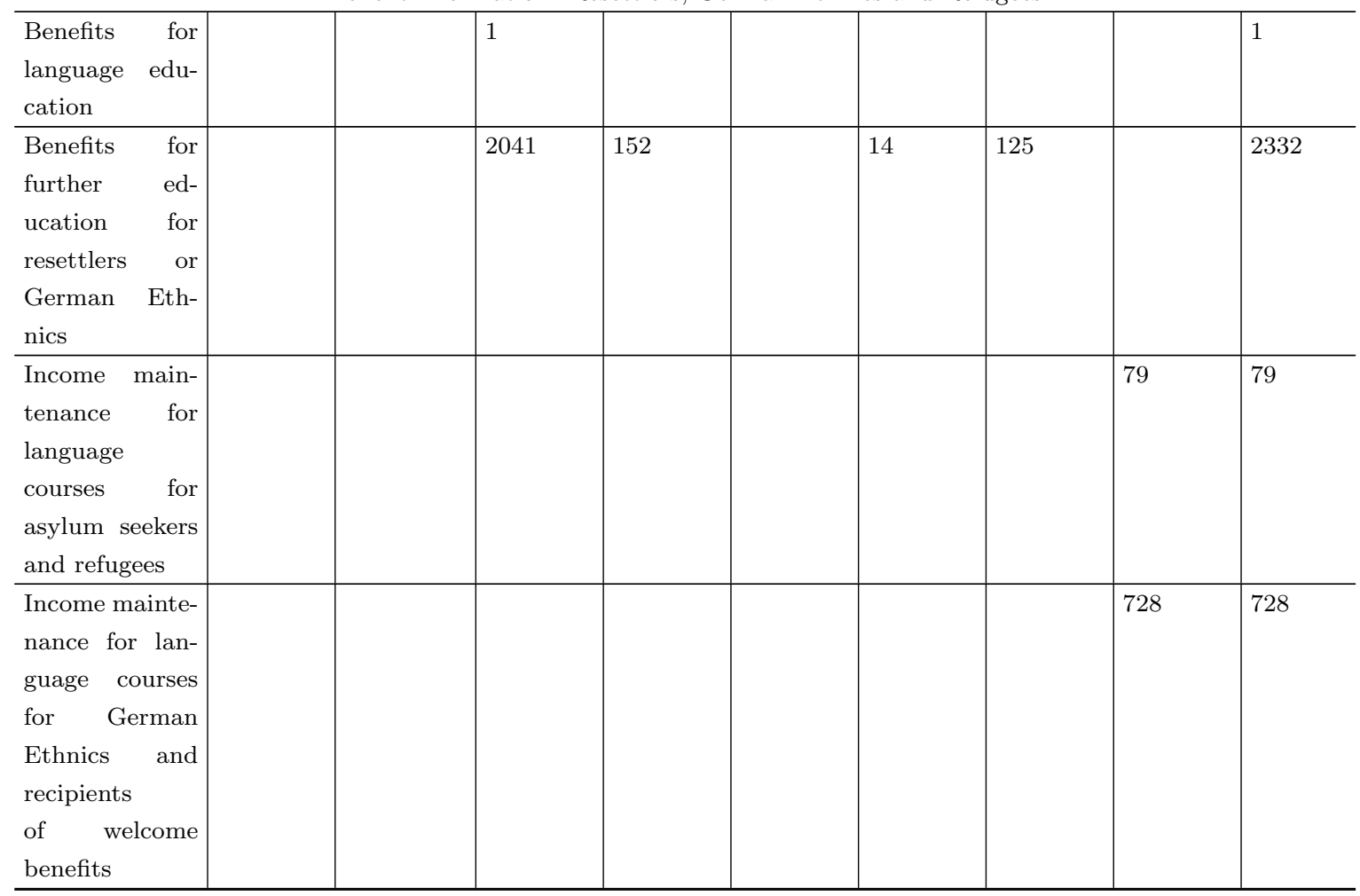

Continued on next page 
Type of training

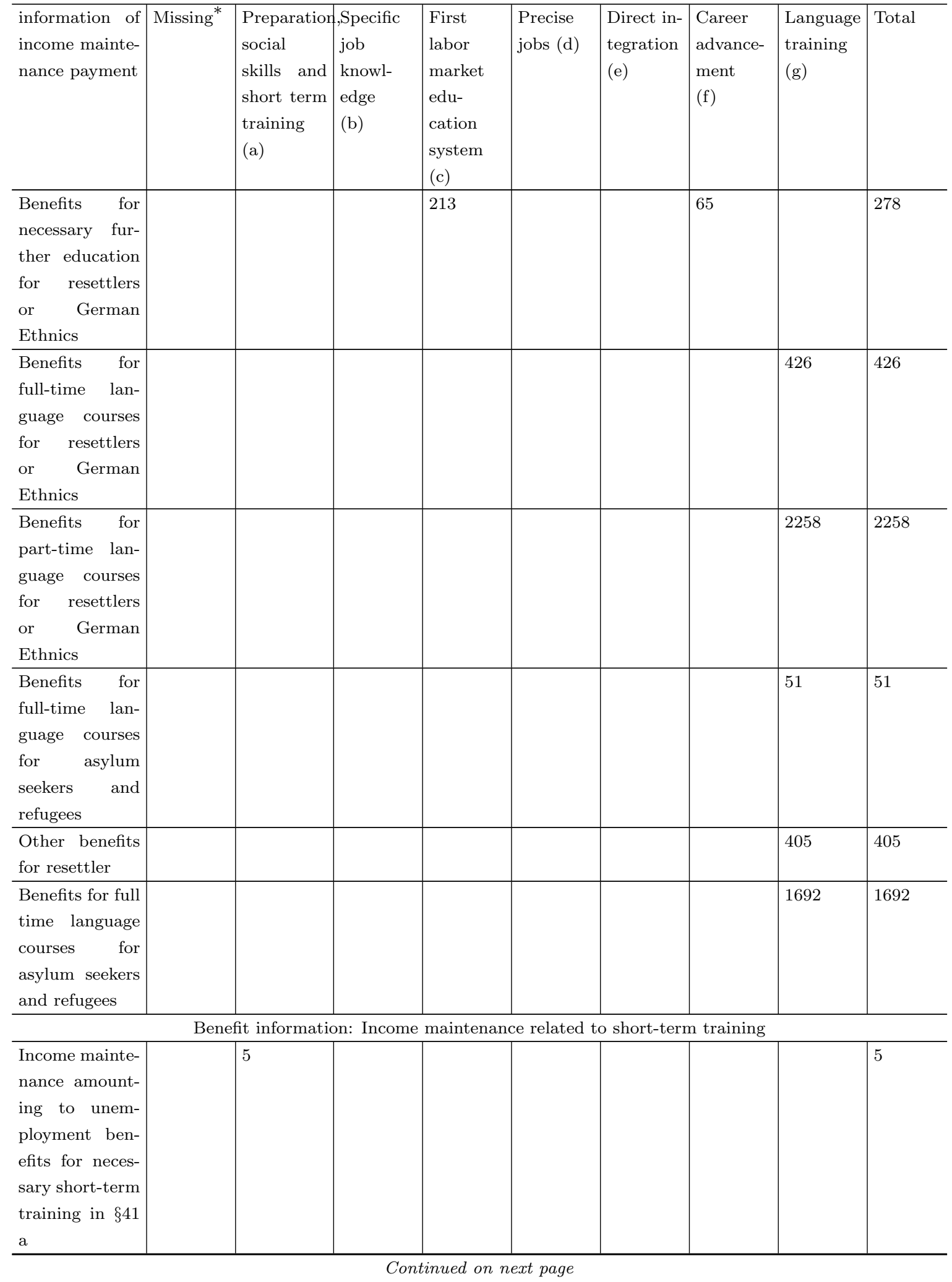


Type of training

\begin{tabular}{|c|c|c|c|c|c|c|c|c|c|}
\hline $\begin{array}{l}\text { information of } \\
\text { income mainte- } \\
\text { nance payment }\end{array}$ & Missing* & $\begin{array}{l}\text { Preparatior } \\
\text { social } \\
\text { skills and } \\
\text { short term } \\
\text { training } \\
\text { (a) }\end{array}$ & $\begin{array}{l}\text {,Specific } \\
\text { job } \\
\text { knowl- } \\
\text { edge } \\
\text { (b) }\end{array}$ & $\begin{array}{l}\text { First } \\
\text { labor } \\
\text { market } \\
\text { edu- } \\
\text { cation } \\
\text { system } \\
\text { (c) }\end{array}$ & $\begin{array}{l}\text { Precise } \\
\text { jobs (d) }\end{array}$ & $\begin{array}{l}\text { Direct in- } \\
\text { tegration } \\
\text { (e) }\end{array}$ & $\begin{array}{l}\text { Career } \\
\text { advance- } \\
\text { ment } \\
\text { (f) }\end{array}$ & $\begin{array}{l}\text { Language } \\
\text { training } \\
\text { (g) }\end{array}$ & Total \\
\hline $\begin{array}{l}\text { Full income } \\
\text { maintenance } \\
\text { because of } \\
\text { unemployment } \\
\text { or in danger of } \\
\text { loosing the job } \\
\text { for necessary } \\
\text { short-term } \\
\text { training in } \S 41 \\
\text { a }\end{array}$ & & 514 & & 4 & & 1 & 255 & & 774 \\
\hline $\begin{array}{l}\text { Income mainte- } \\
\text { nance amount- } \\
\text { ing to unem- } \\
\text { ployment assis- } \\
\text { tance for neces- } \\
\text { sary short-term } \\
\text { training in } \S 41 \\
\text { a }\end{array}$ & & 595 & 6 & 478 & & 2 & 9 & & 1090 \\
\hline
\end{tabular}

Benefit information: Income maintenance related to further vocational training

\begin{tabular}{|c|c|c|c|c|c|c|}
\hline $\begin{array}{l}\text { Income main- } \\
\text { tenance for fur- } \\
\text { ther education, } \\
\text { unemployment } \\
\text { benefit and } \\
\text { conditions for } \\
\text { income main- } \\
\text { tenance not } \\
\text { met, income } \\
\text { maintenance } \\
\text { amounting to } \\
\text { unemployment } \\
\text { benefits paid }\end{array}$ & 62 & 3 & & 14 & & 79 \\
\hline $\begin{array}{l}\text { Income main- } \\
\text { tenance for } \\
\text { necessary fur- } \\
\text { ther education } \\
\text { for unemployed } \\
\text { persons or } \\
\text { persons whose } \\
\text { jobs are in } \\
\text { danger }\end{array}$ & 3963 & 195 & 2 & 744 & 3 & 4907 \\
\hline
\end{tabular}

Continued on next page 
Type of training

\begin{tabular}{|c|c|c|c|c|c|c|c|c|c|}
\hline $\begin{array}{l}\text { information of } \\
\text { income mainte- } \\
\text { nance payment }\end{array}$ & Missing ${ }^{*}$ & $\begin{array}{l}\text { Preparatior } \\
\text { social } \\
\text { skills and } \\
\text { short term } \\
\text { training } \\
\text { (a) }\end{array}$ & $\begin{array}{l}\text { Specific } \\
\text { job } \\
\text { knowl- } \\
\text { edge } \\
\text { (b) }\end{array}$ & $\begin{array}{l}\text { First } \\
\text { labor } \\
\text { market } \\
\text { edu- } \\
\text { cation } \\
\text { system } \\
\text { (c) }\end{array}$ & $\begin{array}{l}\text { Precise } \\
\text { jobs (d) }\end{array}$ & $\begin{array}{l}\text { Direct in- } \\
\text { tegration } \\
\text { (e) }\end{array}$ & $\begin{array}{l}\text { Career } \\
\text { advance- } \\
\text { ment } \\
\text { (f) }\end{array}$ & $\begin{array}{l}\text { Language } \\
\text { training } \\
(\mathrm{g})\end{array}$ & Total \\
\hline $\begin{array}{l}\text { Income mainte- } \\
\text { nance amount- } \\
\text { ing to un- } \\
\text { employment } \\
\text { assistance } \\
\text { because of } \\
\text { necessary fur- } \\
\text { ther education } \\
\text { due to unem- } \\
\text { ployment or } \\
\text { in danger of } \\
\text { loosing the job } \\
\text { as of } 1.1 .94\end{array}$ & & & 369 & 22 & & & 83 & 27 & 501 \\
\hline $\begin{array}{l}\text { Income mainte- } \\
\text { nance for part } \\
\text { time further } \\
\text { education } 44 \\
\text { IIB }\end{array}$ & & & 221 & & & & 2 & 9 & 232 \\
\hline
\end{tabular}

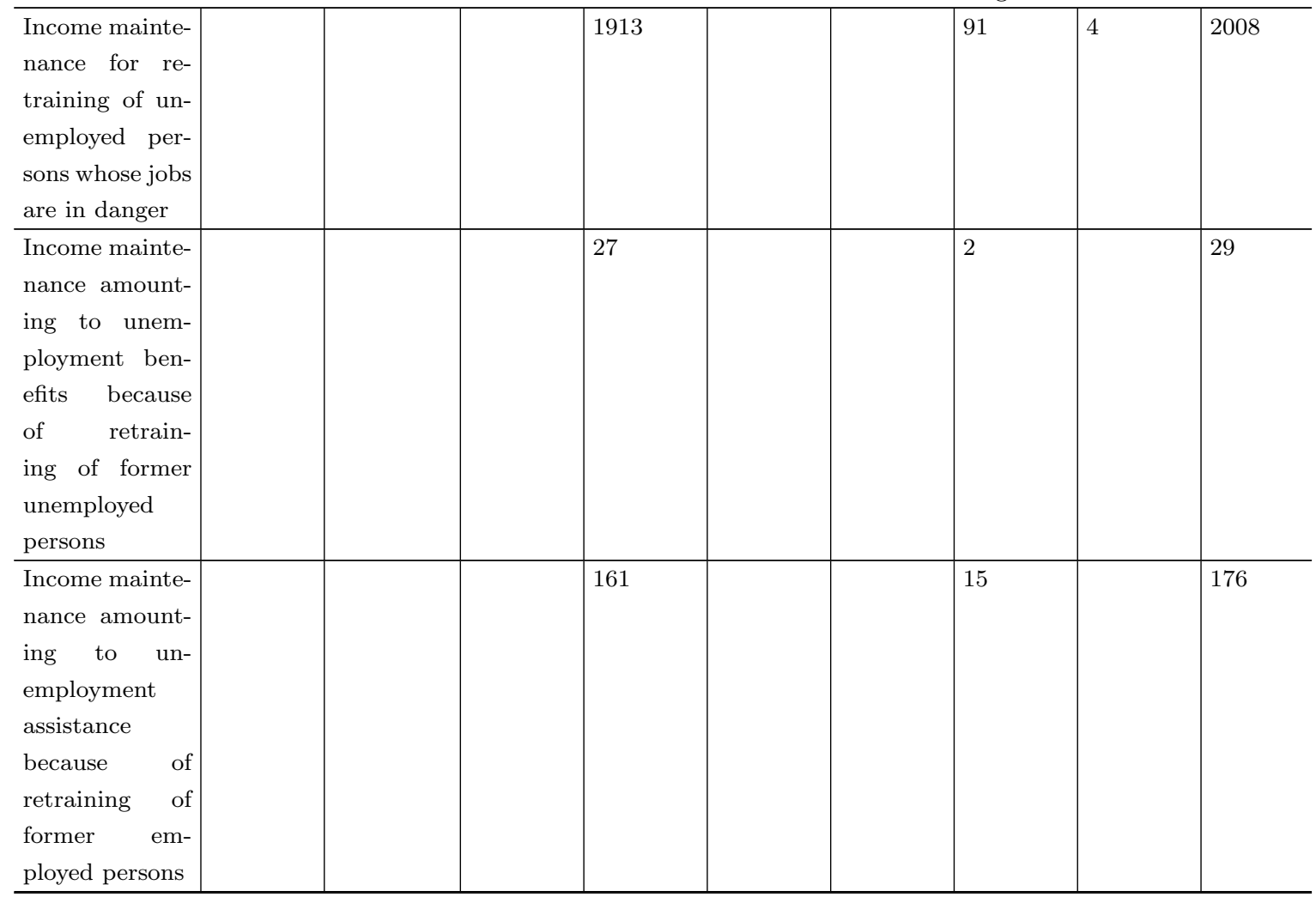

Continued on next page 
Type of training

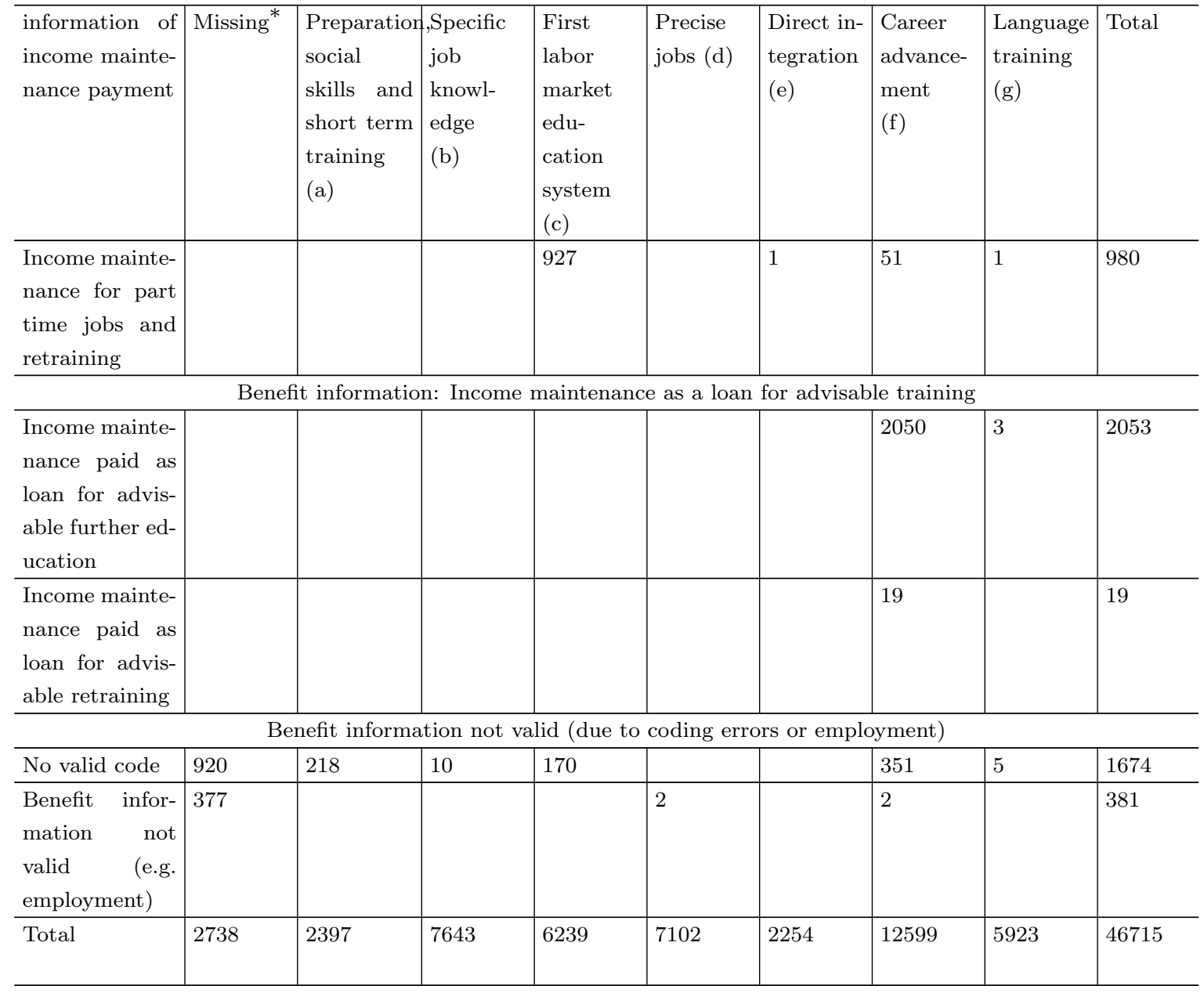

* Missing values originate from codes which were obsolete in the $90 \mathrm{~s}$, but which occur nevertheless for unknown reasons (e.g. benefit information L*LA1 $=315$ ), from an inconsistent combination of short term training according to $\$ 41 \mathrm{a}$ and employment at the same time which could not be interpreted as further training or from codes in the participation data which were not supposed to occur in the 90s (e.g. FMASART* ${ }^{*}=22,23$ ).

${ }^{* *}$ Coding refers to the 90 's

*** In most cases, the training information refers to the participation information from FMASART*, which however does not match to a related benefit information from the IABSLED data (mismatch). In these cases, the training is carried out while individuals were in contributory employment. This usually happens if individuals are granted a career advancement subsidy (39\% of all cases). See Bender et al. (2005) for further sources of failure in matching. 